PNL-5905

UC-95d

$18 \mathrm{~J}$

\title{
Financing Residential Energy Conservation Investment in the Northwest, 1985
}

\author{
J. M. Fang \\ M. P. Hattrup \\ R. T. Nordi \\ D. L. Ivey, Project Manager
}

May 1987

Prepared for the

Bonneville Power Administration

Office of Conservation under a Related Services Agreement

with the U.S. Department of Energy

Contract DE-AC06-76RLO 1830

Pacific Northwest Laboratory

Operated for the U.S. Department of Energy

by Battelle Memorial Institute 


\title{
DISCLAIMER
}

This report was prepared as an account of work sponsored by an agency of the United States Government. Neither the United States Government nor any agency thereof, nor Battelle Memorial Institute, nor any of their employees, makes any warranty, expressed or implied, or assumes any legal liability or responsibility for the accuracy, completeness, or usefulness of any information, apparatus, product, or process disclosed, or represents that its use would not infringe privately owned rights. Reference herein to any specific commercial product, process, or service by trade name, trademark, manufacturer, or otherwise, does not necessarily constitute or imply its endorsement, recommendation, or favoring by the United States Government of any agency thereof, or Battelle Memorial Institute. The views and opinions of authors expressed herein do not necessarly state or reflect those of the United States Government or any agency thereof, or Battelle Memorial Institute.

\author{
PACIFIC NORTHWEST LABORATORY \\ operated by \\ BATTELLE MEMORIAL INSTITUTE \\ for the \\ UNITED STATES DEPARTMENT OF ENERGY \\ under Contract DE-AC06-76RLO 1830
}

\begin{tabular}{|c|c|}
\hline \multicolumn{2}{|c|}{ Printed in the United States of America } \\
\hline \multicolumn{2}{|c|}{$\begin{array}{c}\text { Available from } \\
\text { National Technical Information Service }\end{array}$} \\
\hline \multicolumn{2}{|c|}{ United States Department of Commerce } \\
\hline \multicolumn{2}{|c|}{5285 Port Royal Road } \\
\hline \multicolumn{2}{|c|}{ Springfield, Virginia 22161} \\
\hline \multirow{2}{*}{\multicolumn{2}{|c|}{$\begin{array}{c}\text { NTIS Price Codes } \\
\text { Microfiche A01 }\end{array}$}} \\
\hline & \\
\hline \multicolumn{2}{|c|}{ Printed Copy } \\
\hline & Price \\
\hline Pages & Codes \\
\hline $001-025$ & $\mathrm{~A} 02$ \\
\hline $026-050$ & $\mathrm{~A} 03$ \\
\hline $051-075$ & $\mathrm{~A} 04$ \\
\hline $076-100$ & A05 \\
\hline $101-125$ & A06 \\
\hline $126-150$ & $\mathrm{~A} 07$ \\
\hline $151-175$ & $A 08$ \\
\hline $176-200$ & $A 09$ \\
\hline $201-225$ & A010 \\
\hline $226-250$ & A011 \\
\hline $251-275$ & $\mathrm{~A} 012$ \\
\hline $276-300$ & $A 013$ \\
\hline
\end{tabular}




\author{
J. M. Fang \\ M. P. Hattrup \\ R. T. Nordi \\ D. L. Ivey, Project Manager
}

May 1987

Prepared for Bonneville Power Administration Office of Conservation under a Related Services Agreement with the U.S. Department of Energy under Contract DE-AC06-76RLO 1830

Pacific Northwest Laboratory Richiand, Washington 99352 
.

. :

$\div$

4 
PREFACE

In October and November, 1985 a telephone survey of 1058 households in the Pacific Northwest was conducted as part of a project to analyze the marketing environment for conservation activities of the Bonneville Power Administration $(B P A)$. Analyses of the survey results are being published in a series of five reports:

- a tracking report analyzing the changes between 1983 and 1985

- a financing report focusing on the funding aspects of household energy conservation investments

- a consumer characterization and segmentation report with detailed analyses of market segments

- a fuel switching report detailing the changes in primary and secondary fuel sources in home heating

- a utility summary report presenting a summary of the above four reports with an emphasis on electrical utilities.

The work on this series of reports is conducted by Pacific Northwest Laboratory (PNL) in support of BPA's efforts to develop the capability in delivering conservation programs for use in the future when it becomes necessary to acquire conservation resources. BPA's technical monitor for the project has been Terry 01 iver, Office of Conservation.

This report, entitled Financing Residential Energy Conservation Investments in the Northwest, 1985, PNL-5905, is the second report in the series. It covers aspects such as financing sources of energy conservation investments; demographic and psychographic factors influencing the sources of funding, the impacts of perception of installation of energy conservation measures as home improvement on the amount of investment; as well as the possible threshold level of conservation investments to household income for consumers to finance with loans and the impacts of demographic factors on the threshold levels. The report is based entirely on the 1985 survey data. 
Comments and suggestions on this report are welcome. Please direct your correspondence to Pacific Northwest Laboratory, P.0. Box 999, Richland, Washington 99352.

D. L. Ivey

Project Manager 


\section{EXECUTIVE SUMMARY}

Pacific Northwest Laboratory (PNL) has analyzed how households in the Pacific Northwest financed their investments in energy conservation measures during the 1983-85 period, how they would finance their likely future investments, and related topics regarding conservation investments and financing. The information was collected through a stratified random telephone survey of householders conducted in October/November 1985 in the Bonneville Power Administration (BPA) service area in Idaho, Oregon, Washington and Western Montana. This information will be used by BPA to facilitate the planning, design, and implementation of relevant conservation programs such as the Residential Weatherization Program, and potential programs of bank and utility loans.

COVERAGE AND HYPOTHESES

This report covers the following topics and hypotheses:

- General aspects of households conservation financing.

- Demographic and psychographic influences on financing sources.

- Hypothesis: there are no differences in terms of demographics and psychographics between consumer groups who finance with loans, current income, savings and other sources.

- Hypothesis: Other things being equal, those who view installation of energy conservation measures (ECMs) as home improvement will be willing to spend more than other groups of consumers on conservation.

- Hypothesis: There is a threshold level of spending on conservation above which consumers use loans and/or long-term financing rather than cash or current income. If a threshold exists it will vary by demographics. (The threshold should be calculated as percent of income to control for varying income levels.)

In the following sections, major findings are presented first. Some implications are then summarized. 
GENERAL ASPECTS OF HOUSEHOLD CONSERVATION FINANCING

For all homeowners as well as owners of homes with electric heat, the following findings were derived:

- The most important funding sources for past investments in energy conservation measures are, in the order of importance, current income, savings, loans from banks, utility, and other family members, payments by utility, and other sources.

- The most important potential funding sources for likely future investments in ECMs are, in the order of importance, loans from bank, family or utility, utility payments, current income and savings.

- Given a choice of three different ways of paying for the purchases of major consumer products, consumer's first preference is to pay with cash now, the second choice is to save for future purchases, and the third is to pay by installments.

- Lower income families are more likely than higher income families to prefer savings first over installment payments in financing the purchase of major consumer products.

\section{IMPACTS OF DEMOGRAPHIC AND PSYCHOGRAPHIC FACTORS}

The sources of financing were grouped into four categories: Current income, savings, loans, and "other sources." The category of "other sources" includes payments by utility.

- The following segments of homeowners were more likely to finance their conservation investments with loans:

Past Investments

- Those with at least some college education

- Larger households with 4 or 5 persons

- Those who invested over $\$ 2000$ during 1983-85

- Those who preferred to finance major consumer product purchases with installment payments. 
Potential Future Investments

- Those who prefer to finance major consumer product purchases with installment payments

- Those who use coupons regularly while shopping

- The following groups are more likely to finance their potential future investment with loans and other sources:

- Those who are under 55 years of age

- Those who disagreed with the statement that utilities should stop offering programs to encourage energy conservation.

- Owners of electrically heated homes are more likely to finance potential future investments with "other sources."

INSTALLATION OF ENERGY CONSERVATION MEASURES AS HOME IMPROVEMENT

- The hypothesis that, other things being equal, those who view installation of energy conservation measures as home improvement will be willing to spend more than other groups of consumers on conservation is not supported by the data from the 1985 survey. There are three major reasons for this conclusion. First, the survey questionnaire lacked a direct measure of the perception that installation of energy conservation measures is home improvement. The proxy variables used proved to be inadequate. Second, disaggregation of average conservation investment by the number and type of ECMs did not yield consistent results to allow generalization. Third, the data on the amount of investment made are probably affected by factors such as inaccurate recall and mixing of home remodeling cost with spending on installing ECMs.

\section{THRESHOLD LEVEL OF CONSERVATION INVESTMENT}

- Using repeated applications of 2 by 2 contingency table analysis, the threshold level of conservation investment to household income above which the investment is more likely to be financed with loans is 
tentatively identified at the $2 \%$ level. This means that if, over a two-year period, spending on installation of energy conservation measures exceeded $2 \%$ of annual household income the consumers will become more inclined to finance the spending through loans.

- The threshold level of conservation investment identified above does not appear to be influenced by demographic factors.

\section{IMPL ICATIONS}

- Need for Conservation Financing Programs: Homeowners have indicated a much greater reliance on loans and utility payments for financing future energy conservation investments than they did in financing past investments. It follows that, if it is desirable to keep the number of ECM installations at the same level as in the past two years, it is necessary to maintain programs such as residential weatherization program that help pay for a substantial part of the total cost of ECM installations. It may also be useful to develop or promote programs that permit ready access to bank and utility loans for conservation investments. The need for utility or bank loan programs is further supported by the finding that the threshold level of conservation investment to household income is $2 \%$.

- Targeting Loan Programs: Utility or bank loan programs for funding installation of energy conservation measures would be more effective if targeted towards those homeowners who:

- are under 55 years of age

- have at least some college education

- have relatively large family

- want to invest a relatively large amount on ECMs

- disagree with the statement that utilities should stop offering programs to encourage energy conservation 
- regularly use coupons while shopping

- prefer to finance major consumer product purchases with installment payments.

- Low-Income Subsidies: Low-income homeowners prefer to finance their purchases of major consumer products by saving first. Combined with their relative inability to save, this preference could lead to long delays in actual installation of ECMs. Hence, low-income subsidy programs need to be implemented or maintained, with adjustable level of subsidies to influence the participation by homeowners in this group. 


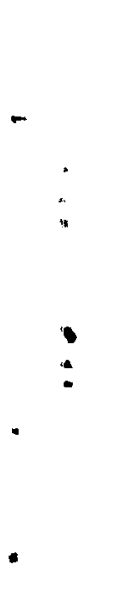

4 


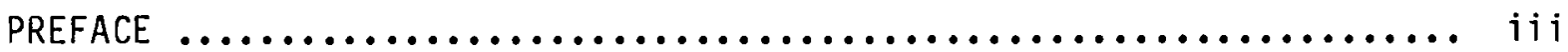

EXECUTIVE SUMMARY $\ldots \ldots \ldots \ldots \ldots \ldots \ldots \ldots \ldots \ldots \ldots \ldots \ldots \ldots \ldots \ldots \ldots$

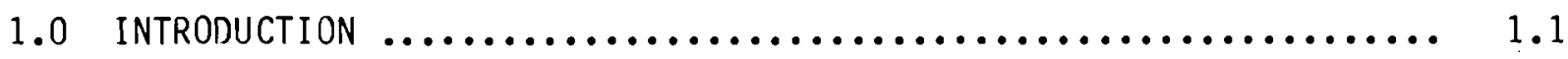

1.1 BACKGROUND AND OBJECTIVES $\ldots \ldots \ldots \ldots \ldots \ldots \ldots \ldots \ldots \ldots \ldots \ldots \ldots \ldots$

1.2 SURVEY DESCRIPTIONS $\ldots \ldots \ldots \ldots \ldots \ldots \ldots \ldots \ldots \ldots \ldots \ldots \ldots \ldots \ldots \ldots$

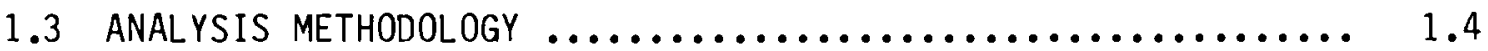

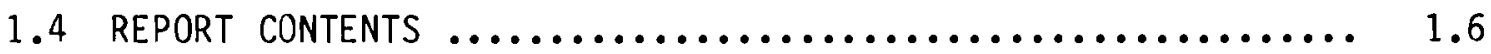

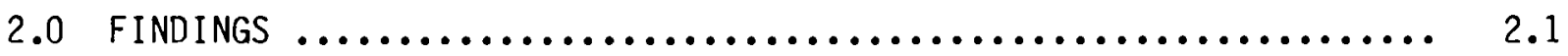

2.1 GENERAL ASPECTS OF CONSERVATION FINANCING $\ldots \ldots \ldots \ldots \ldots \ldots \ldots .2 .1$

2.2 DEMOGRAPHIC AND PSYCHOGRAPHIC INFLUENCES ON

2.3 INSTALLATION OF ENERGY CONSERVATION MEASURES AS HOME

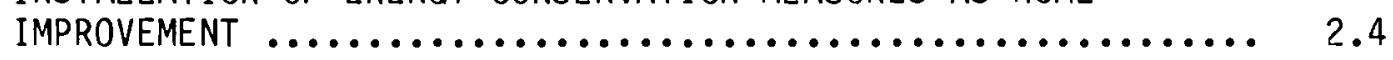

2.4 THRESHOLD LEVELS OF CONSERVATION INVESTMENT FOR FINANCING WITH LOANS .......................... 2.5

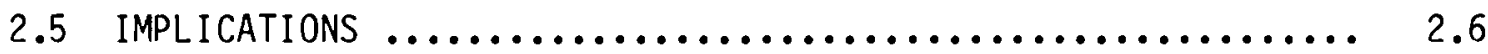

3.0 GENERAL ASPECTS OF CONSERVATION FINANCING $\ldots \ldots \ldots \ldots \ldots \ldots \ldots \ldots . \ldots$

3.1 PAST AND FUTURE FINANCING SOURCES $\ldots \ldots \ldots \ldots \ldots \ldots \ldots \ldots \ldots \ldots . \ldots \ldots$

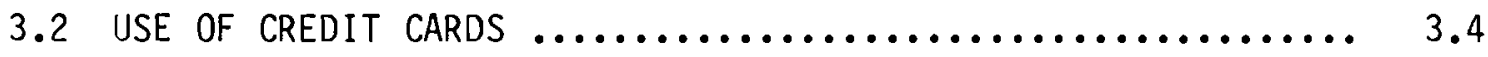

3.3 PREFERENCES CONCERNING FINANCING PURCHASES OF MAJOR
CONSUMER PRODUCTS

3.3.1 Demographic Influences $\ldots \ldots \ldots \ldots \ldots \ldots \ldots \ldots \ldots \ldots . . \ldots$

3.3.2 Influence of Personal Perception ............. 3.13

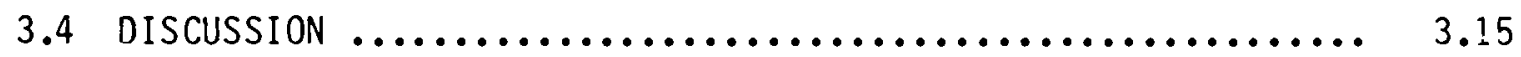

4.0 DEMOGRAPHIC AND PSYCHOGRAPHIC INFLUENCES ON CONSERVATION

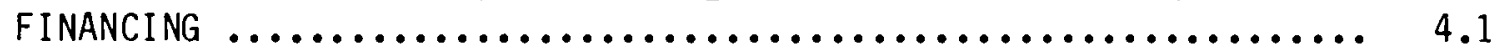


4.1 CATEgORIES OF CONSERVATION FINANCING $\ldots \ldots \ldots \ldots \ldots \ldots \ldots . . . . . .1$

4.2 DEMOGRAPHIC INFLUENCES ON PAST AND FUTURE CONSERVATION

FINANCING

4.2 .1 Age $\ldots \ldots \ldots \ldots \ldots \ldots \ldots \ldots \ldots \ldots \ldots \ldots \ldots \ldots \ldots \ldots, 4.3$

4.2 .2 Education $\ldots \ldots \ldots \ldots \ldots \ldots \ldots \ldots \ldots \ldots \ldots \ldots \ldots, 4.4$

4.2 .3 Household Size $\ldots \ldots \ldots \ldots \ldots \ldots \ldots \ldots \ldots \ldots \ldots \ldots \ldots .4 .5$

4.2.4 Amount of Past Conservation Investment $\ldots \ldots \ldots . . . .4 \quad 4.7$

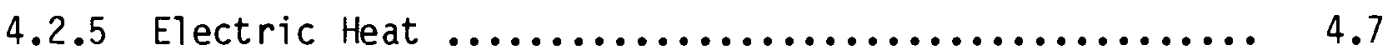

4.2.6 Factors with No Significant Impacts $\ldots . \ldots \ldots \ldots \ldots . . .4 .8$

4.2.7 Factors for which the Test Cannot be Conducted ..... 4.9

4.3 PSYCHOGRAPHIC INFLUENCES ON PAST AND FUTURE CONSERVATION

FINANCING $\ldots \ldots \ldots \ldots \ldots \ldots \ldots \ldots \ldots \ldots \ldots \ldots \ldots \ldots \ldots \ldots, 4.9$

4.3.1 Reasons for Using Credit Cards ................. 4.9

4.3.2 Financing Preferences $\ldots \ldots \ldots \ldots \ldots \ldots \ldots \ldots \ldots \ldots . .6 .10$

4.3.3 Views on Energy Use and Conservation ............ 4.12

4.3.4 Personal Perception and Use of Coupons $\ldots \ldots \ldots \ldots \ldots .4 .14$

4.3.5 Factors with No Significant Impacts $\ldots \ldots \ldots \ldots \ldots . . .64$

4.3.6 Factors for which the Test Cannot be Conducted ...... 4.18

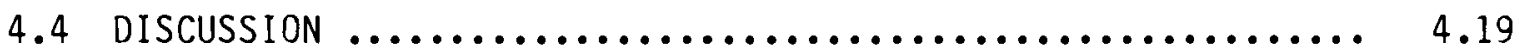

5.0 INSTALLATION OF ENERGY CONSERVATION MEASURES AS HOME

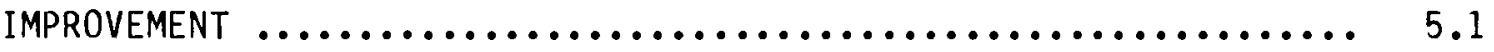

5.1 GENERAL APPROACH $\ldots \ldots \ldots \ldots \ldots \ldots \ldots \ldots \ldots \ldots \ldots \ldots \ldots \ldots \ldots \ldots \ldots \ldots \ldots .1$

5.2 ANALYSIS BASED ON INVESTMENT MADE DURING $1983-85 \ldots \ldots \ldots \ldots .5 .2$

5.2 .1 Data $\ldots \ldots \ldots \ldots \ldots \ldots \ldots \ldots \ldots \ldots \ldots \ldots \ldots \ldots \ldots \ldots, 5.4$

5.2 .2 Regression Results $\ldots \ldots \ldots \ldots \ldots \ldots \ldots \ldots \ldots \ldots \ldots \ldots, 5.5$

5.3 ANALYSIS BASED ON POTENTIAL FUTURE INVESTMENT $\ldots \ldots \ldots \ldots \ldots .5 .12$

5.3 .1 Data $\ldots \ldots \ldots \ldots \ldots \ldots \ldots \ldots \ldots \ldots \ldots \ldots \ldots \ldots \ldots . . .6 .13$ 
5.3.2 Regression Results $\ldots \ldots \ldots \ldots \ldots \ldots \ldots \ldots \ldots \ldots, \quad 5.15$

5.5 DATA ON AVERAGE CONSERVATION INVESTMENTS $\ldots \ldots \ldots \ldots \ldots \ldots . . \ldots .17$

5.4 DISCUSSION $\ldots \ldots \ldots \ldots \ldots \ldots \ldots \ldots \ldots \ldots \ldots \ldots \ldots \ldots \ldots \ldots, 5.22$

6.0 EXPLORATIONS ON DETERMINING THE THRESHOLD LEVEL OF

CONSERVATION INVESTMENT FOR FINANCING WITH LOANS $\ldots \ldots \ldots \ldots \ldots \ldots . . . .$.

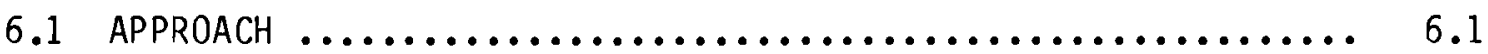

6.2 ANALYSIS OF TOTAL SAMPLE AS A WHOLE $\ldots \ldots \ldots \ldots \ldots \ldots \ldots \ldots . \ldots .6$

6.3 DEMOGRAPHIC AND OTHER INFLUENCES ON THE THRESHOLD LEVEL $\ldots . .6 .9$

6.4 ESTIMATION OF LOGIT MODEL $\ldots \ldots \ldots \ldots \ldots \ldots \ldots \ldots \ldots \ldots \ldots . .6 .17$

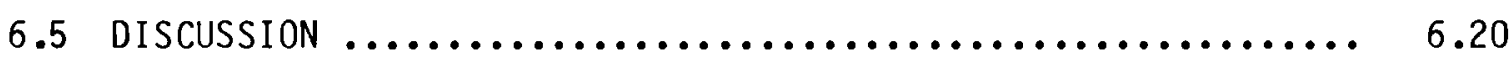

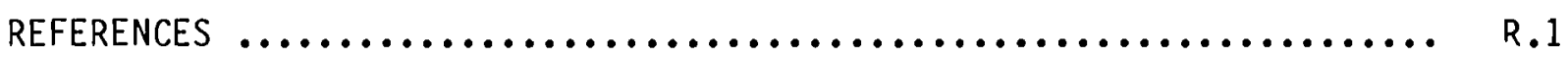

APPENDIX A--SUPPORTING TABLES FOR CHAPTER $4.0 \ldots \ldots \ldots \ldots \ldots \ldots \ldots$ A.1 


\section{FIGURES}

2.1 Plot of the Estimated Logit Model of the Probability of Financing with Loans with the Threshold Level at $2 \%$ of Household Income ................................ 2.6

6.1 Plot of the Estimated Logit Model of the Probability of Financing with Loans with the Threshold Level at $2 \%$ of Household Income 
$\underline{\text { TABLES }}$

3.1 Financing Sources for Energy Conservation Investment Made

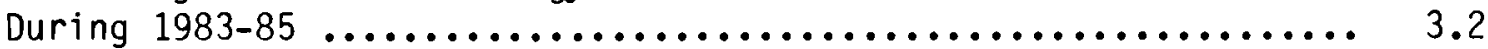

3.2 Financing Sources for Future Conservation Investment ......... 3.3

3.3 Reasons for Using Credit Cards $\ldots \ldots \ldots \ldots \ldots \ldots \ldots \ldots \ldots \ldots \ldots . \ldots \ldots$

3.4 Reasons for Using Credit Cards by Age $\ldots \ldots \ldots \ldots \ldots \ldots \ldots \ldots \ldots . \ldots . \ldots . \ldots$

3.5 Reasons for Using Credit Cards by Gender $\ldots \ldots \ldots \ldots \ldots \ldots \ldots \ldots$

3.6 Reasons for Using Credit Cards by Education $\ldots \ldots \ldots \ldots \ldots \ldots \ldots \ldots$

3.7 Reasons for Using Credit Cards by Household Income $\ldots \ldots \ldots \ldots \ldots . . . .3$

3.8 Consumer Preferences Concerning the Financing of Purchases of Major Consumer Products .......................... 3.8

3.9 Demographic Influences on Preferences for Financing Purchases of Major Consumer Product--Paying Cash Versus Monthly Payments ................................. 3.9

3.10 Demographic Influences on Preferences for Financing Purchases of Major Consumer Products--Monthly Payments Versus Saving for

a Future Purchase ................................... 3.10

3.11 Demographic Influences on Preferences for Financing Purchases of Major Consumer Products--Paying Cash Versus Saving for a

3.12 Summary of Demographic Influences on Preferences of Financing Purchases of Major Consumer Products ................... 3.13

3.13 Impact of Personal Perception of Preferences for Financing Purchases of Major Consumer Product

4.1 Categories of Conservation Financing Sources $\ldots \ldots \ldots \ldots \ldots \ldots \ldots . .4 .2$

4.2 Financing Sources of Conservation Investment During 1984-85 by Age

4.3 Financing Sources of Potential Future Conservation Investment by Age

4.4 Financing Sources of Conservation Investment During 1983-85 by Education Level of the Household 
4.5 Financing Sources of Potential Future Conservation Investment by Education Level of the Household ................. 4.5

4.6 Financing Sources of Conservation Investment During

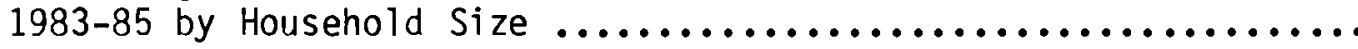

4.7 Financing Sources of Potential Future Conservation Investment by Household Size

4.8 Financing Sources of Conservation Investment During 1983-85 by Amount Invested in Conservation Over the Past Two Years

4.9 Financing Sources of Conservation Investment During 1983-85 by Electric Heat and Nonelectric Heat

4.10 Financing Sources of Potential Future Construction Investment by Electric Heat and Nonelectric Heat

4.11 Financing Sources of Conservation Investment During 1983-85 by Use of Credit Cards

4.12 Financing Sources of Potential Future Conservation Investment by Use of Credit Cards

4.13 Financing Sources of Conservation Investment During 1983-85 by Preference in Financing: Paying Cash Versus Installment Payment

4.14 Financing Sources of Potential Future Conservation Investment by Preference in Financing: Paying Cash Versus

Installment Payments

4.15 Financing Sources of Conservation Investment During 1983-85 by Preference in Financing: Monthly Installment Versus Saving First

4.16 Financing Sources of Potential Future Conservation Investment by Preference in Financing: Monthly Installment Versus Saving First

4.17 Financing Sources of Conservation Investment During 1983-85 by Preference in Financing: Paying Cash Versus Saving First

4.18 Financing Sources of Potential Future Conservation Investment by Preference in Financing: Paying Cash Versus Saving First 
4.19 Financing Sources of Conservation Investment During 1983-85 by Agreement or Disagreement with the Statement:

"Utilities should stop offering a variety of programs

to encourage energy conservation."..................... 4.14

4.20 Financing Sources of Potential Future Conservation Invest-

ment by Agreement or Disagreement with the Statement:

"Utilities should stop offering a variety of programs

to encourage energy conservation." ...................... 4.15

4.21 Financing Sources of Conservation Investment During

1984-85 by Agreement or Disagreement with the Statement:

"I pretty much spend for today and let tomorrow bring

what it will."

4.22 Financing Sources of Potential Future Conservation

Investment by Agreement or Disagreement with the

Statement: "I pretty much spend for today and

let tomorrow bring what it will." ...................... 4.16

4.23 Financing Sources of Conservation Investment During

1984-85 by Agreement or Disagreement with the Statement:

"I usually use coupons when I shop." ..................... 4.16

4.24 Financing Sources of Potential Future Conservation Investment by Agreement or Disagreement with the Statement:

"I usually use coupons when I shop." .................... 4.17

5.1a Unweighted Regression Results for Conservation Investments

Made During 1983-85 ................................ 5.6

5.1b Weighted Regression Results for Conservation Investments

Made During 1983-85 .................................. 5.7

5.2a Unweighted Regression Results for Conservation Investments

Made During 1983-85, Including MECM .................... 5.9

5.2b Weighted Regression Results for Conservation Investments

Made During 1983-85, Including MECM ................... 5.10

5.3 Unweighted Regression Results for the Amount Potentially

Spent on the First Energy Conservation Measure to be

Installed in the Future

5.4 Average Conservation Investments (weighted) Made During 1983-85

by Number of ECMs Installed and Agreement with the Statement

"I would only make conservation improvements which would

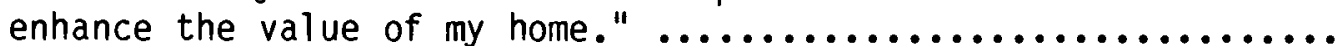


5.5 Average Conservation Investments of (weighted) Homeowners Who Have Installed only One ECM During 1983-85 by ECM and Agreement with the Statement "I would only make conservation improvement which would enhance the value of my home." ...............

5.6 Average Conservation Investments (weighted) of Homeowners Who Have Installed Two ECMs During 1983-85 by Combination of ECMs and Agreement with the Statement "I would only make conservation improvements which would enhance the value of my home .................... 5.19

5.7 Average Conservation Investments (weighted) Made During 1983-85 by Number of ECMs Installed and the Expectation of "More Comfort" Following Installation of the ECMs ................. 5.20

5.8 Average Conservation Investments (weighted) of Homeowners Who Have Installed Only One ECM During 1983-85 by ECM and the Expectation of More Comfort Following Installations .......... 5.20

5.9 Average Conservation Investments (weighted) of Homeowners Who Have Installed Two ECMs During 1983-85 by Combination of ECMs and the Expectation of "More Comfort" Following Installation .... 5.21

6.1 Distribution of Homeowners by the Ratio of 1983-85

Conservation Investment to Household Income ................. 6.5

6.2 Distribution of Homeowners by the Ratio of 1983-85

Conservation Investment to Household Income by Type of Financing

6.3 Summary Results of 2 by 2 Contingency Table Analyses Based

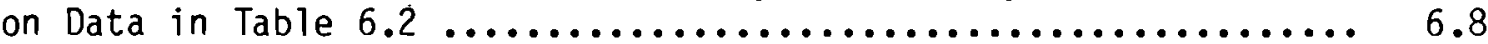

6.4a Unweighted Frequencies for Conservation Investment Made During $1983-85$ by Financing Source and by Demographic and Other Factor

6.4b Weighted Frequencies for Conservation Investment Made During 1983-85 by Financing Source and by Demographic and Other Factor

6.5 Summary Results on Threshold Levels of Conservation Investment of Different Cases by Demographic and Other Variable

6.6 Summary Results of 2 by 2 Contingency Table Analyses for Respondents with at Least Some College Education ..............

6.7 Summary Results of 2 by 2 Contingency Table Analyses for Respondents with Household Income Between $\$ 16,000$ and $\$ 30,000$ 
6.8 Summary Results of 2 by 2 Contingency Table Analyses for Respondents Who Are in the Age Group 35-54 Years 01d

6.9 Summary Results of 2 by 2 Contingency Table Analyses for Respondents with White-Collar Occupation

6.10 Summary Results of 2 by 2 Contingency Table Analyses for Female Respondents

6.11 Summary Results of 2 by 2 Contingency Table Analyses for Respondents Whose 1983-85 Investment was 0ver $\$ 2,000$

6.12 Summary Results of 2 by 2 Contingency Table Analyses for Respondents Who Prefer Paying Cash Now Over Monthly Installments

6.13 Summary Results of 2 by 2 Contingency Table Analyses for Respondents Who Prefer Saving First Over Monthly Installment.....

6.14 Summary Results of 2 by 2 Contingency Table Analyses for Respondents Who Disagree with the Statement "I pretty much spend for today and let tomorrow bring what it will" 
1 


\subsection{INTRODUCTION}

This report presents an analysis of data on financing energy conservation investments collected in a survey of 1,058 households in the Pacific Northwest conducted in November 1985. Pacific Northwest Laboratory (PNL) performed the analyses for the Bonneville Power Administration (BPA) to obtain a better understanding of consumer attitudes and behaviors in financing conservation investments and to facilitate the planning, design and implementation of programs related to conservation financing in the residential sector.

\subsection{BACKGROUND AND OBJECTIVES}

During 1983-84, PNL conducted the Phase I study of consumer energy conservation attitudes for the BPA. The study was part of an overall project designed to assess the marketing environment for BPA's programs and activities. It was the first comprehensive regional study of its kind and established a baseline for comparison in future studies.

In the baseline study, a telephone survey of 2000 residents of the Northwest was conducted. (a) The sample was drawn to be a representative crosssection of consumers in the Northwest and was composed of 500 respondents from each of the four geographic divisions: Western Washington; Western Oregon; Eastern Oregon and Southern Idaho; Eastern Washington, Northern Idaho, and Western Montana. The respondents were adult heads of households. Only one respondent per household was interviewed. Eighty percent of the interviews were conducted during evening and weekend hours between october 30 and November 13, 1983. Seventy-five percent of the interviews lasted approximately 20 minutes. Interviews with the remaining respondents lasted approximately 30 minutes longer because of additional questions relating specifically to heat pump and solar water heaters.

The results of the baseline study (RMH Research, Inc. 1984a) were published and compared with results from other studies (Fang 1985). A companion

(a) The survey was conducted by RMH Research Inc. of River Edge, New Jersey. 
survey on the marketing environment for solar and heat pump water heaters was al so conducted (RMH Research, Inc. 1984b).

In July 1985, PNL undertook Phase II of the project to analyze the marketing environment for BPA conservation activities with the following three objectives:

1. to track changes in consumer attitudes, interests and opinions between 1983 and 1985

2. to identify more refined segments of the residential conservation market in terms of attitudes, interests, and opinions

3. to test hypotheses concerning consumer conservation actions and investment behaviors.

To achieve these objectives, a second survey of Northwest consumers was conducted in late 1985. This report provides the data, information, and analyses to achieve the part of objective 3 concerning conservation financing. Specifically, it describes the sources of financing conservation investment made during 1983 to 1985 and potential future investments, and related consumer behaviors in using credit cards, as well as paying for purchases of major consumer products. It also tests the following three hypotheses:

Hypothesis No. 1. There are no differences in terms of demographics and psychographics between consumer groups who finance with loans, current income, savings, and other sources.

Hypothesis No. 2. Other things being equal, those who view installation of energy conservation measures as home improvement will be willing to spend more than other groups of consumers on conservation.

Hypothesis No. 3. There is a threshold level of spending on conservation above which consumers use loans and/or long-term financing rather than cash or current income. If a threshold exists, it will vary by demographics. (The threshold should be calculated as a percent of income to control for varying income levels). 


\subsection{SURVEY DESCRIPTIONS}

In the 1985 survey, 1,058 telephone interviews were completed. The sample was drawn from the four states of Idaho, Oregon, Washington, and Western Montana, with about equal number of respondents from each of the same four geographical divisions as in the 1983 sample. Interviews were conducted from October 15 through November 8, 1985. Calls were made from 4 p.m. to 9 p.m. on weekdays and from 10:30 a.m. to 7 p.m. on Saturdays and Sundays. Each interview took between 35 and 45 minutes to complete. Approximately $13 \%$ of the households contacted by phone refused to be interviewed. About $10 \%$ of the households that did initially participate terminated the interview at some point during the survey. (a) While the survey included both homeowners and renters, the analysis of conservation financing concentrates on homeowners because renters do not typically make modifications to their residence. Of the total 1,058 responses, there are 766 homeowners and 292 renters.

The data presented in this report have been weighted to approximate population values in the BPA service area. The populations of counties within each of the four geographic divisions in the BPA service area were determined and summed. This yielded a total population count for each geographic division. The total counts for the four geographic divisions were then summed to arrive at a total population for the BPA service area. The populations of each division were then expressed as a percentage of the total population of the region. The weights were derived by comparing the sample observations for the

(a) For detailed description of sampling design, survey procedure, and survey instrument, see Columbia Research Center, 1985 Marketing Environment for BPA Conservation Activities: Phase II, Draft report submitted to Pacific Northwest Laboratory, December 6, 1985, Port land, Oregon. 
geographic divisions with their respective divisional populations. All population values were approximated by using the 1980 Census data. (a)

\subsection{ANALYSIS METHODOLOGY}

Much of the data collected in the Phase II survey is categorical (nominal), therefore the appropriate statistical test for the null hypothesis that there is no relationship between the two variables used in classifying the observations would be chi square, a nonparametric statistic. Since there were no specific expectations as to how the data should be distributed, contingency table analysis with the chi square procedure was used in the analys is on the general aspects of conservation financing and the hypothesis that there are no differences in terms of demographics and psychographics between consumer groups who finance with loans, current income, savings, and other sources (Hypothesis No. 1).

Chi square is considered to be a valid test if no more than 20 percent of the cells in a contingency table have frequencies less than 5, and none of the cells are empty. In many instances these qualifications could not be met by a particular analysis, therefore a footnote on the tables indicates that statistical testing could not be done. Otherwise the tables will indicate whether the chi square results are statistically significant, and if so, the appropriate statistical information will be given.

(a) Total number of households in the Pacific Northwest for 1980 is $3,022,490$. The details of the weights by geographic division are as follows:

\begin{tabular}{|c|c|c|c|c|c|}
\hline $\begin{array}{c}\text { Geographic } \\
\text { Division } \\
\end{array}$ & $\begin{array}{c}\text { Relative } \\
\text { Weight }\end{array}$ & $\begin{array}{l}\% \text { of Total } \\
\text { Households }\end{array}$ & $\begin{array}{l}\text { Households } \\
\text { in Division }\end{array}$ & $\begin{array}{l}\text { Households } \\
\text { in Sample } \\
\end{array}$ & $\begin{array}{c}\text { Weight for } \\
\text { Division }\end{array}$ \\
\hline $\begin{array}{l}\text { W. Washington } \\
\text { W. Oregon } \\
\text { E. Washington, } \\
\text { N. Idaho, \& } \\
\text { W. Montana }\end{array}$ & $\begin{array}{l}1.58 \\
1.12 \\
0.73\end{array}$ & $\begin{array}{l}39.50 \\
20.80 \\
18.25\end{array}$ & $\begin{array}{r}1,193,884 \\
846,297 \\
551,604\end{array}$ & $\begin{array}{l}258 \\
270 \\
274\end{array}$ & $\begin{array}{l}4,627.5 \\
3,134.4 \\
2,013.2\end{array}$ \\
\hline E. Oregon \& & 0.57 & 14.25 & 430,705 & 256 & $1,682.4$ \\
\hline Total & 4.00 & 100.00 & $3,022,490$ & 1,058 & -- \\
\hline
\end{tabular}


The proportions presented in this report are computed by excluding those respondents who indicated "don't know" or refused to answer a specific question from the total number of respondents. They are different from the proportions reported in the tracking report (Fang et al. 1986). Moreover, since the BPA is primarily concerned with homes with electric heat, they are also separately out when judged to be appropriate.

To test the hypothesis that, other things being equal, those who view installations of energy conservation measures (ECMS) as home improvement will be willing to spend more than other groups of consumers on conservation (Hypothesis No. 2), regression analysis using dummy variables was applied. Since the individual consumer either holds the view that installation of ECMs is home improvement or not, a dummy variable could be used to represent such a viewpoint. The dummy variable assumes a value of 1 for those who view conservation investment as home improvement and a value of 0 (zero) for those who don't hold this view. The regression analysis permits controlling for other variables such as income or number of measures installed. The sign and statistical significance of the coefficient of the dummy variable for viewing ECM installations as home improvement would lead to the acceptance or rejection of the null hypothesis that there was no difference in the amount of investment made by those with different views on ECM installation as home improvement. This analysis was supplemented by a detailed disaggregation of the average investments by the number and type of ECMs installed.

For Hypothesis No. 3, potential threshold levels were identified through a trial and error approach of conducting successive 2 by 2 contingency table analyses at different assumed levels of the ratio of conservation to household income. The specific threshold level was identified at the lowest level of the investment to income ratio where the chi-square test first becomes significant for the particular distribution. Once the threshold level was identified, a logit model was used to approximate the probability distribution of a household financing its conservation investment with loans as a function of the investment to income ratio. 


\subsection{REPORT CONTENTS}

Chapter 2 provides an overview of the findings derived from the analyses conducted in this study and discusses some of the implications. Chapter 3 covers the general information on consumer attitudes toward conservation financing for past and future investments, reasons consumers use credit cards, and consumer preferences concerning the financing of purchases of major consumer products. Chapter 4 analyzes the impacts of demographics and psychographics on conservation financing and tests the hypothesis that there are no differences in terms of demographics and psychographics between consumer groups who finance with loans, current income, savings, and other sources. Chapter 5 assesses whether viewing conservation investment as home improvements makes a difference in the amount consumers invested or are likely to spend on conservation. The hypothesis that, other things being equal, those who view installation of energy conservation measures as home improvement will be willing to spend more than other groups of consumers on conservation was tested. Chapter 6 explores the threshold levels of conservation investment over which homeowners are more likely to finance with loans. Appendix A provides support for Chapter 4 by presenting data tables for which the statistical tests were either not significant or could not be conducted. 


\subsection{FINDINGS}

Chapters 3.0 through 6.0 present detailed analyses and discussions of data and information with respect to financing energy conservation investment in the 1985 survey. This chapter provides a summary of the findings and conclusions. Some implications are also discussed. In sequence, the topics covered are: general aspects of conservation financing; demographic and psychographic influences on financing sources; the results on testing the hypothesis on viewing energy conservation measures (ECM) installation as home improvement; the threshold level of investment in ECMs for financing with loans; and implications.

\subsection{GENERAL ASPECTS OF CONSERVATION FINANCING}

For conservation investments made during the 1983-85 period, the principal important sources of funding were, in order of importance, current income $(63 \%),(a)$ savings (19\%), loans from banks, utility, and family (10\%), payments by utility $(3 \%)$, and other sources such as delay or cutback on other purchases, paid by others, federal tax credits, combined sources (about 5\%). However, for potential future investments, consumers were much more likely to indicate that they would finance with bank and family loans (40\%) and utility loans (10\%) or to expect that installation of ECMs be paid by the utility (26\%). They were less likely to say that such spending would be funded through current income (12\%) or savings $(9 \%)$.

These findings are generally true for all homeowners as well as for owners of electrically heated homes.

Since financing conservation spending with loans may involve the use of credit cards, the reasons for using credit cards were also analyzed. Almost two-thirds $(65 \%)$ of the homeowners indicated that they would use a credit card for its convenience or that they did not like carrying cash. About a quarter (25\%) of the respondents said that they used credit cards because they often did not have enough cash or that it would allow them to buy things they would

(a) The proportion shown in parentheses following each funding source is the percentage of respondents who indicated the specific funding source accounting for the largest part of spending. 
not be able to afford otherwise. Only about $5 \%$ mentioned installment payments specifically. The rest $(5 \%)$ mentioned other assorted reasons for using credit card such as habit, for the purpose of identification, to establish credit and so forth.

While the reasons for using a credit card were not affected by education and income, they were affected by age and gender. 01 der respondents were more likely than younger respondents to use a credit card for its convenience or because they dislike carrying cash. In contrast, younger respondents were more likely to say they used a credit card because they often did not have enough cash or that using a credit card allows them to purchase things they otherwise couldn't afford. While male respondents were more likely than female respondents to use a credit card for the convenience, female respondents were more likely to use them because they often did not have enough cash or because the card allows them to buy things they otherwise couldn't afford.

Installation of ECMs resembles the purchase of major consumer products. Hence, it is useful to see how consumers rank the different ways of funding the purchase of major consumer products. Given a choice of three different ways of paying for the purchase of major consumer products, the first choice of the consumers was to pay cash now. The second choice was to save first for future purchase. The third and last choice was paying by monthly installments.

- Respondents with some college education were more likely to prefer paying cash now over monthly installments.

- Higher income respondents were more likely to prefer financing with monthly installments over saving first.

- Male, higher income respondents or those with some college education were more likely to prefer paying cash now over saving first for a future purchase.

- Respondents who agreed with the statement that "I pretty much spend for today and let tomorrow bring what it will" were more likely to prefer monthly installments over paying cash now. 


\subsection{DEMOGRAPHIC AND PSYCHOGRAPHIC INFLUENCES ON CONSERVATION FINANCING}

The sources of funds for financing conservation investments during 1983-85 or for potential future investment did not appear to be influenced by many of the demographic and psychographic variables considered. In this sense, the hypothesis that there are no differences in terms of demographics and psychographics between consumer groups who finance with loans, current income, savings, and other sources (Hypothesis No. 1) was confirmed by the data collected in the 1985 survey. However, the following are exceptions to the above. generalization:

- Compared to respondents who were over 55 years old, those who were under 55 years of age were more likely to finance potential future investments with loans and "other sources" and were less likely to finance with current income and savings.

- Households with at most a high school education were more likely than those with at least some college education to have financed past conservation investment with current income, and were less likely to have done so with loans.

- Larger households (with 4 or 5 members) were more likely to finance past investments with loans and less likely to finance with savings than were households with only 1 or 2 members.

- Respondents whose past investment was greater than $\$ 2000$ were more likely to finance with loans and less likely to finance with current income or other sources.

- Owners of homes with electric heat were more likely than owners of nonelectric heat homes to be inclined to fund potential future conservation investments with "other sources" (which included payment by the utility) and less likely to finance with current income.

- Respondents who preferred to finance the purchase of major consumer products with installment payments were more likely to finance both past and potential future investments with loans and less likely to finance with savings. 
- Respondents who preferred paying cash now over saving first were more likely to finance potential future conservation investment with current income, and less likely to use "other sources."

- Those who agreed that utilities should stop offering programs to encourage energy conservation were more likely (than those who disagreed) to have financed their past conservation investments with current income, and less likely to have financed with loans, savings, and other sources.

- Those who agreed with the statement that "I pretty much spend for today" were more likely than those who disagreed to finance past conservation investments with current income and less likely to pay for such investments out of savings.

- Those who used coupons regularly while shopping were more likely than those who did not to finance future investments with loans.

\subsection{INSTALLATION OF ENERGY CONSERVATION MEASURES AS HOME IMPROVEMENT}

The hypothesis that viewing installing of ECMs as home improvement tends to raise the amount of spending on conservation was tested by regression analyses conducted using the data on conservation investments made during 1983-85 and potential future investment. The hypothesis cannot be confirmed for several reasons. 1) The 1985 survey questionnaire did not include a question that would directly represent the consumer perception that installing ECMs is a home improvement. The proxy variables used in the analysis proved to be inadequate. 2) Disaggregation of average conservation investments by the number and the type of ECMs did not yield consistent results to allow generalization. 3) The conservation investment data are probably affected by factors such as inaccurate recall and mixing of home remodeling cost with spending on installing ECMs. Therefore, data on conservation spending would probably require substantial processing to separate out the outliers or extreme values. 


\subsection{THRESHOLD LEVELS OF CONSERVATION INVESTMENT FOR FINANCING WITH LOANS}

Using the data from household investments in energy conservation made during the 1983-85 period and the 2 by 2 contingency table analysis, it was found that a threshold level of conservation investment to household income ratio existed above which consumers are more likely to finance their investment with loans. Without controlling for demographic or other variables, this threshold level was tentatively identified at the $2 \%$ level.(a) Controlling for demographic or attitudinal variables, the threshold level was also identified at the $2 \%$ level for six of the nine cases considered. In one case involving respondents who preferred saving first over monthly installments in funding the purchase of major consumer products, the threshold level was identified at the $3 \%$ level. No threshold level was identified in the other two cases: one involving respondents whose investment during 1983-85 was over $\$ 2000$ and the other involving respondents who disagreed with the statement that "I pretty much spend for today and let tomorrow bring what it will." Thus it is tentatively concluded that Hypothesis No. 3 is partially confirmed: There was a threshold level of conservation spending above which consumers are more likely to finance with loans and the threshold was at the $2 \%$ level of annual household income. On the other hand, available data did not support the idea that the threshold level varies with demographics.

Figure 2.1 presents the plot of the logit model estimated to approximate the probability distribution of individual households which would finance conservation investment with loans.

Note, however, that this conclusion was based on a sample which included only 29 households which financed installations of ECMs with loans, out of an

(a) Note that the $2 \%$ is computed by dividing the amount of conservation investment over the two-year period of 1983-1985 by the annual household income. The actual "burden" on the household would be only about $1 \%$ of the two-year income. This qualification applies to the discussion on the threshold level of investment throughout this report. 


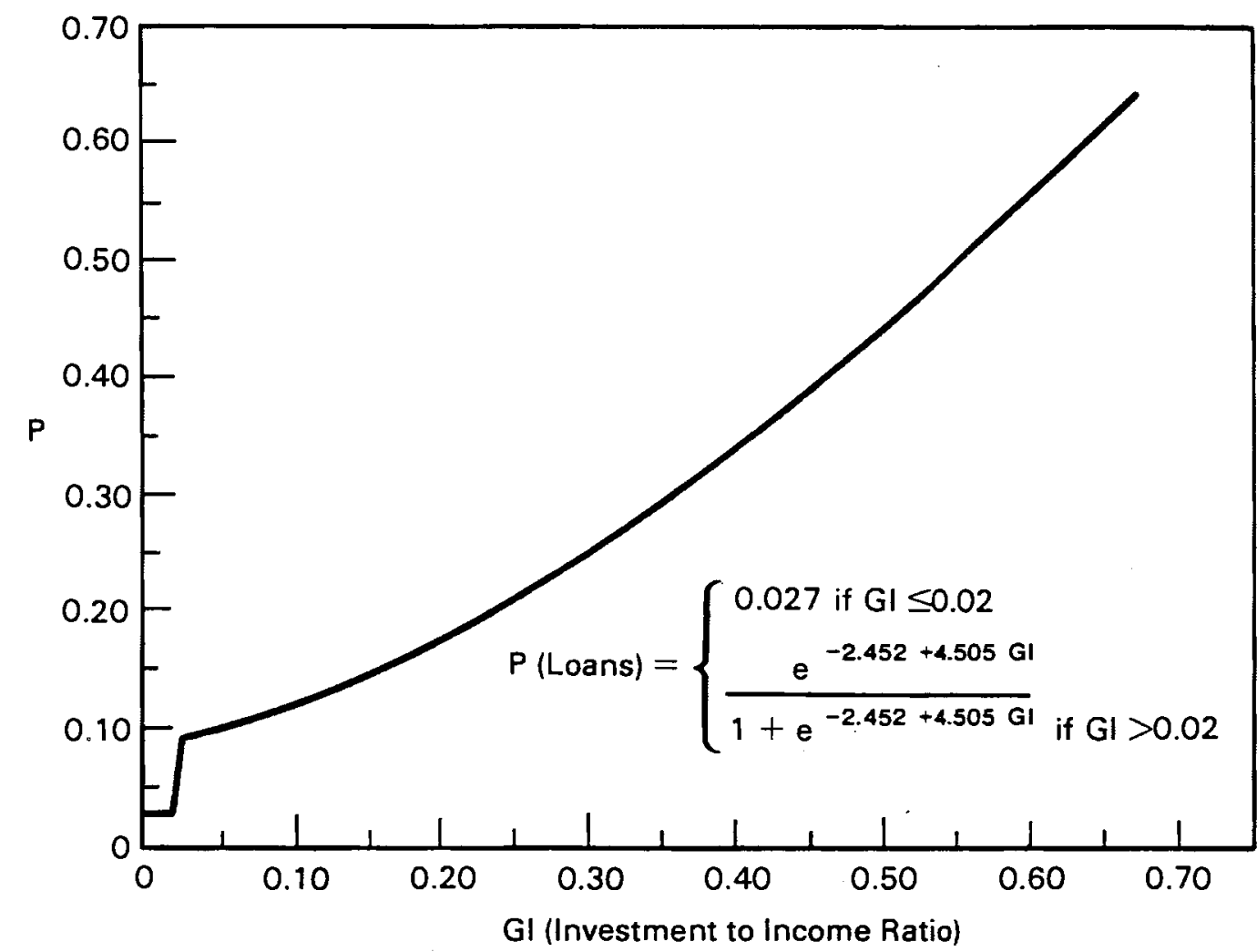

FIGURE 2.1. Plot of the Estimated Logit Model of the Probability of Financing with Loans with the Threshold Level at $2 \%$ of Household Income

effective sample of 316 homeowners. The small number of households financing with loans severely restricted the applicability of the 2 by 2 contingency table analysis to subsamples when the individual demographic variables were controlled.

\subsection{IMPLICATIONS}

Several implications of the findings summarized above can be briefly noted.

First, while past conservation investments were financed mainly through current income and savings, about $75 \%$ of consumers indicated that they expected to finance their potential future investment with loans (50\%) and utility payments $(26 \%)$. Although several explanations are possible, this finding suggests that, if it is desirable to keep the number of ECM installations at the same level as in the past two years, it is necessary to maintain programs, such as 
the residential weatherization program, which help pay for a substantial part of total costs of ECM installations. In addition, programs which would permit ready access to bank and utility loans may need to be developed or promoted.

Second, the ranking by consumers of the three ways to pay for purchases of major consumer products was, in the order of choice, 1) to pay cash now, 2) to save first for a future purchase, and 3) to pay by monthly installments. This finding suggests a relative aversion to incur debt. This preference ranking was contradicted by the finding on the funding sources for potential future conservation investment mentioned above. This may suggest that the motivation for investing in energy conservation measures is weaker than that for purchases of major consumer products. Nevertheless, the finding on future funding sources deserves further investigation.

Third, respondents with incomes less than $\$ 16,000$ prefer saving first over monthly installments. Since this income group's ability to save may be limited, their funding preference may mean long delays in installing ECMs. To promote installations of ECMs by homeowners in this income group, financial assistance such as that offered in the low income weatherization program may be necessary.

Fourth, the following groups were more likely to finance these investments with loans: consumers who were under 55 years of age; those with at least some college education or a large household, those who invested more than $\$ 2000$, or those with electric heat. Hence bank and utility loan programs to promote energy conservation may be targeted with these groups in mind. Similarly, to reach those who prefer to finance the purchase of major consumer products with installment payments rather than saving first, loan availability and "easy" installment payments may be featured in promotional programs. Furthermore, to increase participation of bank or utility loan programs for financing the installation of ECMs, promotion may be targeted at market segments such as those who disagreed with the statement that "utilities should stop offering a variety of programs to encourage energy conservation" and those who regularly used coupons while shopping.

Fifth, the hypothesis that those who view installing ECMs as home improvement were willing to spend more on conservation cannot be supported by the 
current data. In future surveys, it will be necessary to include questions that will capture consumer perception of ECM installation as home improvement in a more direct and positive way than did the questions in the 1985 questionnaire.

Finally, given that the threshold level of conservation investment is at $2 \%$ of household income, the threshold level of investment is $\$ 400$ for households with incomes at $\$ 20,000$ and $\$ 800$ for those with income of $\$ 40,000$. Such absolute threshold levels were exceeded by the average conservation investment of $\$ 1570$ for homeowners who have spent money on ECM installations. The ECMs being installed include weatherproofing, ceiling, wall, and floor insulation, storm doors, storm windows, setback or automatic thermostats, heat pump furnaces, heat pump water heaters, solar panels for water heating, wood stoves, and fireplace inserts. Installing a combination of several items at the same time is likely to lead to a total spending exceeding the threshold levels. Hence many consumers might be looking for ways to finance their future investment with loans. This suggests that conservation financing programs such as bank and utility loans may be important in promoting conservation investments in the future. This is even more important given the first item discussed above. 


\subsection{GENERAL ASPECTS OF CONSERVATION FINANCING}

This chapter presents an overview of conservation financing and related consumer attitudes on the use of credit cards and preferences concerning financing the purchase of major consumer products. The sources of financing for conservation investments made during the 1983-85 period and for future conservation investments are discussed first. In this discussion, homes with electricity as the primary or the secondary heating fuel are separately noted. Since financing conservation spending with loans may involve the use of credit cards and since such spending resembles purchases of major consumer products, the reasons consumers use credit cards and their preferences concerning the financing of purchases of major consumer products are then discussed. The final section discusses the implications of some of the findings.

\subsection{PAST AND FUTURE FINANCING SOURCES}

Question 150 of the survey instrument asked the respondent: "of everything spent on energy conservation for your home, where did the highest proportion of money come from?" Table 3.1 indicates that the most important source of financing for conservation investment made during the 1983-85 period was current income. About 6 out of 10 respondents (63\%) indicated that current income was the major source of funding. Saving was the second most important source, accounting for almost $20 \%$. Loans from banks and family were mentioned by $8 \%$ of the respondents. Loans from a utility were mentioned by $2 \%$ of the respondents. Therefore, loans of all types account for about $10 \%$ of respondents as the major funding sources of conservation investment. Utility payments for the cost of installing energy conservation measures was mentioned by about $3 \%$ of the respondents. The other items mentioned were payments by others such as a state agency or the previous owner, Federal income credits, combined sources, insurance settlements, and receipts from property sales.

Table 3.1 also suggests that the distribution of funding sources for ECM investments in homes with electricity as the primary or secondary heating fuels is essentially identical with that for all owner-occupied homes. It is interesting to note, however, that $5 \%$ of the owners of electrically heated homes 
TABLE 3.1. Financing Sources for Energy Conservation Investment Made During 1983-85

\begin{tabular}{|c|c|c|c|c|}
\hline Item & $\begin{array}{l}\text { All } \\
\text { Number of } \\
\text { Homeowners } \\
\text { (in 1000s) } \\
\end{array}$ & $\%$ & $\begin{array}{l}\text { Electric He } \\
\text { Number of } \\
\text { Homeowners } \\
\text { (in 1000s) } \\
\end{array}$ & (a) \\
\hline Current Income & 1101 & 63 & 625 & 63 \\
\hline Savings & 333 & 19 & 177 & 18 \\
\hline Bank/Family Loans & 143 & 8 & 74 & 7 \\
\hline Payments by Utility & 59 & 3 & 47 & 5 \\
\hline Utility Loans & 38 & 2 & 19 & 2 \\
\hline Delay/Cutback Other Purchases & 29 & 2 & 17 & 2 \\
\hline Combined Sources & 27 & 2 & 23 & 2 \\
\hline Paid by Others & 9 & 1 & 7 & 1 \\
\hline Federal Tax Credit & 10 & 0 & 3 & 0 \\
\hline Other & $\frac{4}{1753^{(b)}}$ & $\frac{0}{100}$ & $\frac{2}{995(b)}$ & $\frac{0}{100}$ \\
\hline
\end{tabular}

(a) Electricity is the primary or secondary heating fuel.

(b) Excludes responses of "don't know" or refusal to answer the specific question.

indicated that payments were made by utilities, compared to only $3 \%$ for all owner-occupied homes. This is consistent with the fact that electric utilities operated residential weatherization programs which paid a large part of the costs of ECMs recommended by the home energy audit.

The survey also asked the consumer the following question: "If you were interested in getting funding for energy conservation measures for your home, where would you obtain it?" (Question 151) Table 3.2 summarizes the responses to this question. It suggests a quite different pattern from that concerning past financing sources. Loans from banks and family was the most important source, accounting for about $40 \%$ of the respondents who gave a specific answer to the question. The second most important source was the utility; about 1 in 4 respondents (26\%) mentioned this financing source. Note that this mention means that the utility will pay for it outright, not that the utility would provide a loan. Utility loan is a separate category which was mentioned 
TABLE 3.2. Financing Sources for Future Conservation Investment

\begin{tabular}{|c|c|c|c|c|}
\hline Item & $\begin{array}{l}\text { All } \\
\text { Number of } \\
\text { Homeowners } \\
\text { (in 1000s) } \\
\end{array}$ & $\%$ & $\begin{array}{l}\text { Electric He } \\
\text { Number of } \\
\text { Homeowners } \\
\text { (in 1000s) }\end{array}$ & (a) \\
\hline Bank/Family Loans & 605 & 40 & 350 & 39 \\
\hline Paid by Utility & 397 & 26 & 271 & 30 \\
\hline Current Income & 190 & 12 & 86 & 10 \\
\hline Savings & 138 & 9 & 66 & 7 \\
\hline Utility Loan & 157 & 10 & 94 & 10 \\
\hline Tax Credit & 23 & 2 & 20 & 2 \\
\hline Paid by Others & 15 & 1 & 10 & 1 \\
\hline Combined Sources & 4 & 0 & 4 & 0 \\
\hline Other & $\frac{2}{1531^{(b)}}$ & $\frac{0}{100}$ & $\frac{2}{903^{(b)}}$ & $\frac{0}{100}$ \\
\hline
\end{tabular}

(a) Electricity is the primary or secondary heating fuel.

(b) Excludes responses of "don't know" or refusal to answer the specific question.

by about $10 \%$ of the respondents as the major source of funding for the spending on ECMs. Current income was mentioned by $12 \%$ of the respondents, and savings by about $9 \%$ of the respondents. All other sources combined was mentioned by less than $5 \%$ of the respondents.

The data on homes with electric heat show a generally similar pattern of distribution in the sources of funds for financing investment in ECMs as the homeowners in general. Consistent with the fact that electric utilities had operated residential weatherization programs, the proportions of homeowners with electric heat who expected that the utility would pay for installations of ECMs was slightly higher than the overall average, $30 \%$ versus $26 \%$. It might be the residential weatherization programs implemented in the last few years by electric utilities in the region have led to the expectation of utility payment or financing of future conservation investment.

However, it is not clear why consumers expressed a higher propensity to finance future conservation investment with loans than was the case with 
respect to their past investments. Detailed discussions of demographic and psychographic influences on conservation investment financing will be presented in the next chapter.

\subsection{USE OF CREDIT CARDS}

Consumers' spending habits may be reflected in the reasons they use credit cards to make purchases. Question 153 in the survey instrument asked the respondents: "What is the main reason why you'd use a credit card for any purposes?" About two-thirds (65\%) of homeowners indicated that they would use credit cards for the convenience or that they didn't like to carry cash. A quarter $(25 \%)$ of the homeowners said that they would use a credit card because they often did not have enough cash or because the card would allow them to buy things they otherwise couldn't afford. Only 5\% of the homeowners said that credit cards allowed them to make installment payments. The rest (5\%) gave other assorted reasons such as habit, emergencies, travel, identification, tax receipts, to establish credit, for use in buying gasoline only, business, and cheap interest (Table 3.3).

The reasons for using credit cards are significantly affected by age. 01 der respondents were more likely than younger respondents to use a credit card for its convenience or because they dislike carrying cash: $75 \%$ for those over 55 years old, compared with $55 \%$ for those under 34 years old. Conversely, younger respondents were more likely than older respondents to say that they

\section{TABLE 3.3. Reasons for Using Credit Cards}

\begin{tabular}{|c|c|c|}
\hline Item & $\begin{array}{l}\text { Number of } \\
\text { Homeowners } \\
\text { (in 1000s) }\end{array}$ & $\%$ \\
\hline Convenience/Don't like to carry cash & 926 & 65 \\
\hline Never seem to have cash/buying things otherwise can't & 367 & 25 \\
\hline Installment payment & 70 & 5 \\
\hline Other & 70 & 5 \\
\hline Total & 1433 & 100 \\
\hline
\end{tabular}


use credit cards because they often did not have enough cash or that using credit cards allows them to purchase things they otherwise couldn't afford: $36 \%$ versus $15 \%$ (Table 3.4 ).

Male respondents were more likely than female respondents to indicate that they use credit cards for the convenience. Seventy four percent of male respondents, compared with $59 \%$ of female respondents, so indicated. In contrast, $30 \%$ of female respondents, compared with $19 \%$ of male respondents, said that they would use credit cards because they often did not have enough cash or using credit cards would allow them to buy things they otherwise couldn't afford (Table 3.5).

Education and income did not appear to affect the reasons consumers use credit cards in making purchases (Tables 3.6 and 3.7 ).

\subsection{PREFERENCES CONCERNING FINANCING PURCHASES OF MAJOR CONSUMER PRODUCTS}

To ascertain consumers' preferences concerning the financing of purchases of major consumer products, a series of questions (154 through 157) were included in the survey instrument:

TABLE 3.4. Reasons for Using Credit Cards, by Age

\begin{tabular}{|c|c|c|c|}
\hline \multirow[b]{2}{*}{ Item } & \multicolumn{3}{|c|}{$\begin{array}{c}\text { Number of Homeowners (in 1000s) } \\
\qquad(n=1398)\end{array}$} \\
\hline & $\begin{array}{l}\text { Under } \\
34 \text { Years } \\
(n=328) \\
\end{array}$ & $\begin{array}{c}35-54 \\
\text { Years 01d } \\
(n=640) \\
\end{array}$ & $\begin{array}{c}\text { Over } 55 \\
\text { Years } 01 \mathrm{~d} \\
(\mathrm{n}=430) \\
\end{array}$ \\
\hline Convenience/Don't like to carry cash & $55 \%$ & $62 \%$ & $75 \%$ \\
\hline $\begin{array}{l}\text { Never seem to have cash/buy things otherwise } \\
\text { couldn't }\end{array}$ & 36 & 28 & 15 \\
\hline Installment payment & 4 & 5 & 5 \\
\hline Other & 5 & 4 & 5 \\
\hline
\end{tabular}


TABLE 3.5. Reasons for Using Credit Cards by Gender

\begin{tabular}{lcc}
\multicolumn{1}{c|}{ Item } & $\begin{array}{c}\text { Number of Home- } \\
\text { owners (in 1000s) } \\
(n=1433)\end{array}$ \\
\hline $\begin{array}{l}\text { Convenience/Don't like to carry cash } \\
\text { Never seem to have cash/Buy things otherwise couldn't } \\
\text { Installment payment }\end{array}$ & $\begin{array}{c}\text { Male } \\
(n=533)\end{array}$ & $\begin{array}{c}\text { Female } \\
(n=900)\end{array}$ \\
Other & $44 \%$ & $39 \%$ \\
\hline$x^{2}=11.292, P=0.010$. & 4 & 6
\end{tabular}

TABLE 3.6. Reasons for Using Credit Cards by Education

\begin{tabular}{|c|c|c|}
\hline \multirow[b]{2}{*}{ Item } & \multicolumn{2}{|c|}{$\begin{array}{c}\text { Number of Homeowners } \\
(\text { in 1000s) } \\
(n=1424)\end{array}$} \\
\hline & $\begin{array}{c}\text { High } \\
\text { School or } \\
\text { Less } \\
(n=550) \\
\end{array}$ & $\begin{array}{c}\text { Some } \\
\text { College or } \\
\text { More } \\
(n=874) \\
\end{array}$ \\
\hline Convenience/Don't like to carry cash & $63 \%$ & $66 \%$ \\
\hline Never seem to have cash/Buy things otherwise couldn't & 29 & 24 \\
\hline Installment payments & 3 & 6 \\
\hline Other & 5 & 5 \\
\hline
\end{tabular}

(a) No significance.

Question 154: Let's say you've decided to buy a new T.V. set and you have the choices of: paying for it all with cash now; making . monthly payments over the next year (12 months); or starting to save now in order to buy the T.V. in one year (12 months).

Question 155: Which of these do you prefer? Cash now or monthly payments? 
TABLE 3.7. Reasons for Using Credit Cards by Household Income

\begin{tabular}{|c|c|c|c|}
\hline \multirow[b]{2}{*}{ Item } & \multicolumn{3}{|c|}{$\begin{array}{c}\text { Number of Homeowners } \\
(\text { in 1000s }) \\
(n=1316)\end{array}$} \\
\hline & $\begin{array}{l}\text { Under } \\
\$ 16,000 \\
(n=203) \\
\end{array}$ & $\begin{array}{l}\$ 16,000- \\
\$ 30,000 \\
(n=486)\end{array}$ & $\begin{array}{l}\text { Over } \\
\$ 30,000 \\
(n=628) \\
\end{array}$ \\
\hline Convenience/Don't like to carry cash $61 \%$ & $63 \%$ & $67 \%$ & \\
\hline $\begin{array}{l}\text { Never seem to have cash/Buy things otherwise } \\
\text { couldn't }\end{array}$ & 30 & 24 & 25 \\
\hline Installment payments & 3 & 7 & 4 \\
\hline Other & 6 & 6 & 4 \\
\hline
\end{tabular}

Question 156: Which of these do you prefer? Monthly payments or saving for a future purchase?

Question 157: Which of these do you prefer? Cash now or saving for

future purchase?

Almost 9 out of 10 respondents (88\%) preferred paying cash now over monthly payments; only about 1 out of $10(12 \%)$ preferred monthly installments over paying cash now. Of 10 respondents, about 7 (72\%) preferred saving first over monthly installment payments; the other $3(28 \%)$ preferred monthly instal1ments over saving first. Similarly, 7 out of $10(72 \%)$ respondents indicated the preference of paying cash over saving first (Table 3.8). These results suggest that there was a relative aversion to finance with loans or installment payments. Given the three choices, paying cash was the first preference; saving for future purchase was the second preference, and paying by monthly installments was the last choice. In other words, consumers preferred to buy and pay now so that they would not incur additional debt. Their second choice appeared to be to defer immediate satisfaction by saving first and buying later. The buying-now-and-paying-later-approach (i.e., debt) was the last choice. 
TABLE 3.8. Consumer Preferences Concerning the Financing of Purchases of Major Consumer Products

\begin{tabular}{|c|c|c|}
\hline Item & $\begin{array}{l}\text { Number of } \\
\text { Homeowners } \\
\text { (in 1000s) }\end{array}$ & $\%$ \\
\hline \multicolumn{3}{|l|}{ Question 155} \\
\hline Prefer cash now & 1874 & 88 \\
\hline \multirow[t]{2}{*}{ Prefer monthly payments } & 258 & 12 \\
\hline & 2132 & 100 \\
\hline \multicolumn{3}{|l|}{ Question 156} \\
\hline Prefer monthly payments & 570 & 28 \\
\hline \multirow[t]{2}{*}{ Saving first for future purchase } & 1481 & 72 \\
\hline & 2051 & 100 \\
\hline \multicolumn{3}{|l|}{ Question 157} \\
\hline Prefer cash now & 1503 & 72 \\
\hline \multirow[t]{2}{*}{ Saving for future purchase } & 581 & 28 \\
\hline & 2084 & 100 \\
\hline
\end{tabular}

This finding is consistent with the results presented in Section 3.1 concerning the funding sources of past investment. The major sources of funding, in terms of importance are current income, savings, and loans.

\subsubsection{Demographic Influences}

This section presents the results of analyzing the influences of age, gender, income and education of the respondent on the preferences of the financing of purchases of major consumer products. It appears that the preference for paying cash now over installment payments was not influenced by age, gender, or income. It was, however, affected by the education of the respondent. Those respondents with at least some college education are more likely than those with only at most high school education to prefer paying cash now over monthly installments, $91 \%$ versus $84 \%$ (Table 3.9 ).

Table 3.10 suggests that age, gender or education did not influence the preference for installment payments over saving first for a future purchase. However, income did have minor impacts: High-income households were more likely than those with lower income to prefer financing with monthly 
TABLE 3.9. Demographic Influences on Preferences for Financing Purchases of Major Consumer Product--Paying Cash Versus Monthly Payments (Number of Homeowners in 1000s)

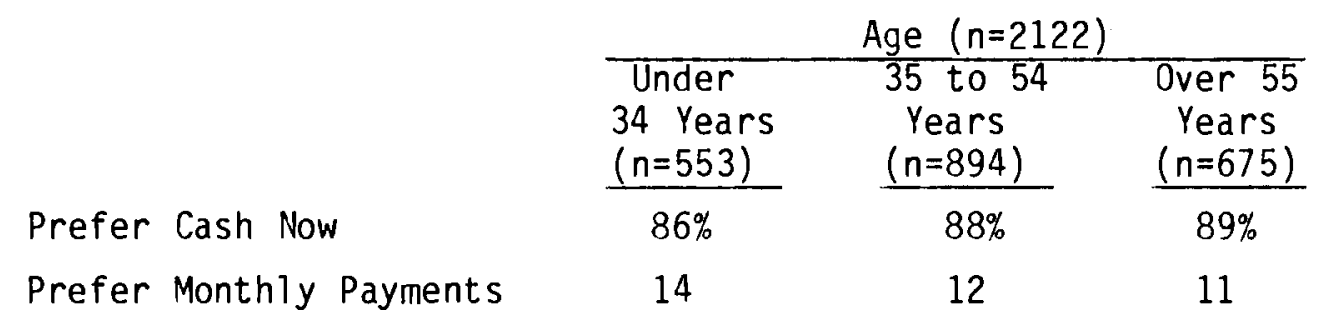

No significance.

Prefer Cash Now

Prefer Monthly Payments

\begin{tabular}{|c|c|}
\hline \multicolumn{2}{|c|}{ Gender $\quad(n=2131)$} \\
\hline $\begin{array}{l}\text { Male } \\
(n=782)\end{array}$ & $\begin{array}{l}\text { Female } \\
(n=1349)\end{array}$ \\
\hline $88 \%$ & $88 \%$ \\
\hline 12 & 12 \\
\hline
\end{tabular}

Prefer Cash Now

No significance.

Prefer Monthly Payments

\begin{tabular}{|c|c|c|}
\hline \multicolumn{3}{|c|}{ Income $(n=1972)$} \\
\hline $\begin{array}{c}\text { Under } \\
\$ 16,000 \\
(n=449)\end{array}$ & $\begin{array}{c}\$ 16,000- \\
\$ 3,000 \\
(n=733)\end{array}$ & $\begin{array}{c}\text { Over } \\
\$ 30,000 \\
(n=790)\end{array}$ \\
\hline $88 \%$ & $87 \%$ & $89 \%$ \\
\hline 12 & 13 & 11 \\
\hline
\end{tabular}

No significance.

Prefer Cash Now

Prefer Monthly Payments

$\chi^{2}=8.801, P=0.003$

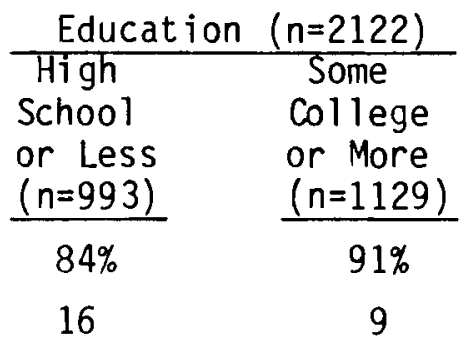


TABLE 3.10. Demographic Influences on Preferences for Financing Purchases of Major Consumer Products--Monthly Payments Versus Saving for a Future Purchase (Number of Homeowners in 1000s)

Prefer Monthly Payments

\begin{tabular}{|c|c|c|}
\hline \multicolumn{3}{|c|}{ Age $(n=2012)$} \\
\hline $\begin{array}{l}\text { Under } \\
34 \text { Years } \\
(n=513) \\
\end{array}$ & $\begin{array}{l}35 \text { to } 54 \\
\text { Years } \\
(n=880)\end{array}$ & $\begin{array}{l}\text { Over 55 } \\
\text { Years } \\
(n=619) \\
\end{array}$ \\
\hline $30 \%$ & $29 \%$ & $24 \%$ \\
\hline 70 & 71 & 76 \\
\hline
\end{tabular}

No significance.

Prefer Monthly Payments

\begin{tabular}{|c|c|}
\hline \multicolumn{2}{|c|}{ Gender $(n=2051)$} \\
\hline $\begin{array}{l}\text { Male } \\
(n=748)\end{array}$ & $\begin{array}{l}\text { Female } \\
(n=1304)\end{array}$ \\
\hline $30 \%$ & $27 \%$ \\
\hline 70 & 73 \\
\hline
\end{tabular}

No significance.

Prefer Monthly Payments

Prefer Saving for a Future Purchase

$x^{2}=6.719, P=0.035$.
Prefer Monthly Payments

Prefer Saving for a Future Purchase

\begin{tabular}{|c|c|c|}
\hline \multicolumn{3}{|c|}{ Income $(n=1895)$} \\
\hline $\begin{array}{l}\text { Under } \\
\$ 16,000 \\
(n=426)\end{array}$ & $\begin{array}{r}\$ 16,000- \\
\$ 3,000 \\
(n=720)\end{array}$ & $\begin{array}{c}\text { Over } \\
\$ 30,000 \\
(n=748)\end{array}$ \\
\hline $33 \%$ & $25 \%$ & $33 \%$ \\
\hline 77 & 75 & 67 \\
\hline
\end{tabular}

\begin{tabular}{|c|c|}
\hline Educat & 04 \\
\hline $\begin{array}{l}\text { High } \\
\text { School } \\
\text { or Less } \\
(n=971) \\
\end{array}$ & $\begin{array}{l}\text { Some } \\
\text { Coll lege } \\
\text { or More } \\
(n=1071)\end{array}$ \\
\hline 29 & $27 \%$ \\
\hline & \\
\hline
\end{tabular}

No significance. 
installments over saving first for a future purchase. Thirty-three percent of households with annual income over $\$ 30,000$, compared to 1ess than $25 \%$ of those families with income lower than $\$ 30,000$, preferred monthly payments over saving first.

The preference for paying cash now over saving first for a future purchase was significantly affected by gender, income and education of the respondents. There were also indications that the age of the respondent may have some impact, although the impact was only significant at the $10 \%$ level (Table 3.11 ). Male respondents were more likely than female respondents to prefer paying cash now over saving first for a future purchase; $79 \%$ of male respondents, compared to only $68 \%$ of female respondents, so indicated.

Households with higher income were more likely to prefer paying cash now over saving first than were lower income households. $81 \%$ of households with income over $\$ 30,000$ preferred paying cash now over saving first. This can be compared with $71 \%$ for households with income in the $\$ 16,000$ to $\$ 30,000$ range and $59 \%$ for those with annual income under $\$ 16,000$.

Respondents with some college education were more likely than those with at most a high school education to prefer to pay cash now over saving first for future purchases: $77 \%$ versus $67 \%$. As for the influence of age, $71 \%$ to $76 \%$ of those respondents over 35 years old preferred to pay cash now over saving first. This can be compared with $66 \%$ of those who are under 34 years old.

Table 3.12 summarizes the demographic influences on consumer preferences for funding the purchases of major consumer products. Among the four demographic factors considered, age did not appear to have any impacts at all. In contrast, education, gender and income do have some impacts:

- Those respondents with some college education were more likely than those with at most a high school education to prefer paying cash now over monthly installments.

- Households with income over $\$ 30,000$ were more likely than households with lower income to prefer financing with monthly installment over saving first for a future purchase. 
TABLE 3.11. Demographic Influences on Preferences for Financing Purchases of Major Consumer Products--Paying Cash Versus Saving for a Future Purchase (Number of Homeowners in 1000s)

Prefer Cash Now

Prefer Saving for a Future Purchase

\begin{tabular}{|c|c|c|}
\hline \multicolumn{3}{|c|}{ Age $(n=2045)$} \\
\hline Under & 35 to 54 & Over 55 \\
\hline $\begin{array}{l}34 \text { Years } \\
(n=516)\end{array}$ & $\begin{array}{l}\text { Years } \\
(n=866)\end{array}$ & $\begin{array}{c}\text { Years } \\
(n=662)\end{array}$ \\
\hline $66 \%$ & $76 \%$ & $71 \%$ \\
\hline 34 & 24 & 29 \\
\hline
\end{tabular}

$x^{2}=5.290, P=0.071$

Prefer Cash Now

Prefer Saving for a Future Purchase

$x^{2}=9.958, P=0.002$
Prefer Cash Now

Prefer Saving for a Future Purchase

$X^{2}=22.789, P=0.000$
Prefer Cash Now

Prefer Saving for a Future Purchase

\begin{tabular}{|c|c|c|}
\hline \multicolumn{3}{|c|}{ Income $(n=1932)$} \\
\hline $\begin{array}{c}\text { Under } \\
\$ 16,000 \\
(n=439)\end{array}$ & $\begin{array}{c}\$ 16,000- \\
\$ 3,000 \\
(n=721)\end{array}$ & $\begin{array}{c}\text { Over } \\
\$ 30,000 \\
(n=772)\end{array}$ \\
\hline $59 \%$ & $71 \%$ & $81 \%$ \\
\hline 41 & 29 & 19 \\
\hline
\end{tabular}

$$
X^{2}=9.443, P=0.002 \text {. }
$$

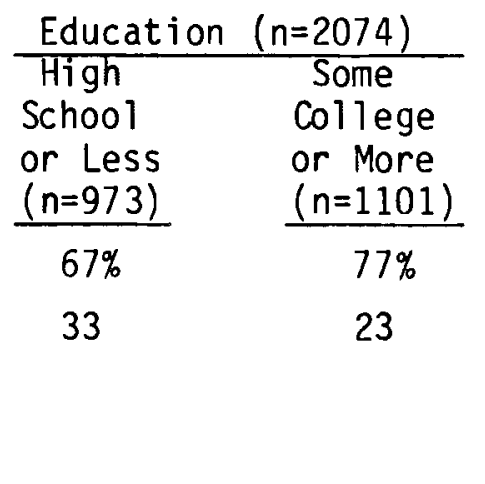


TABLE 3.12. Summary of Demographic Influences on Preferences of Financing the Purchases of Major Consumer Products

\begin{tabular}{|c|c|c|c|c|}
\hline $\begin{array}{c}\text { Demographic } \\
\text { Factor } \\
\end{array}$ & $\begin{array}{r}\text { Prefer Paying } \\
\text { Cash Now Over } \\
\text { Monthly Installment } \\
\end{array}$ & $\begin{array}{c}\text { Prefer Saving } \\
\text { First Over } \\
\text { Monthly Installment } \\
\end{array}$ & $\begin{array}{l}\text { Prefer } \\
\text { Cash N } \\
\text { Saving } \\
\end{array}$ & $\begin{array}{l}\text { Paying } \\
\text { Now Over } \\
\text { girst } \\
\end{array}$ \\
\hline \multicolumn{5}{|l|}{ Gender } \\
\hline Male & -- & -- & more & likely \\
\hline Female & -- & - & less & likely \\
\hline \multicolumn{5}{|l|}{ Age } \\
\hline Under 34 years & - & - & & -- \\
\hline $35-54$ years & -- & -- & & -- \\
\hline over 55 years & - & -- & & -- \\
\hline \multicolumn{5}{|l|}{ Education } \\
\hline High school or less & less likely & -- & less & likely \\
\hline Some college or more & more likely & -- & more & likely \\
\hline \multicolumn{5}{|l|}{ Income } \\
\hline under $\$ 16,000$ & -- & more likely & less & likely \\
\hline$\$ 16,000-\$ 30,000$ & -- & more likely & more & likely \\
\hline over $\$ 30,000$ & -- & less likely & most & likely \\
\hline
\end{tabular}

- Male or high income respondents or those with at least some college education were more likely than their respective counterparts to prefer paying cash over saving first.

\subsubsection{Influence of Personal Perception}

Question 174 asked the respondent to indicate whether or not he or she agreed with the following statement: "I pretty much spend for today and let tomorrow bring what it will." Those who agreed with this statement may be grouped into the "living for today" category. This personal perception appeared to influence the choice of preferences for financing purchases of major consumer products, except for the choice between paying cash now and saving first for a future purchase (Table 3.13). Those respondents who perceived themselves as belonging to the "living for today" category were more likely than those who did not perceive themselves as belonging to this category, to prefer monthly installments over paying cash now (20\% versus $10 \%$ ). 
TABLE 3.13. Impact of Personal Perception(a) on Preferences for Financing Purchases of Major Consumer Product (Number of Homeowners in 1000s)

Prefer Cash Now

Prefer Monthly Payments

$X^{2}=7.939, P=0.005$

Prefer Monthly Payments

Prefer Saving for a Future Purchase

$X^{2}=4.366, P=0.037$
Prefer Cash Now

Prefer Saving for a Future Purchase

\begin{tabular}{cc}
\multicolumn{2}{c}{$(n=2075)$} \\
$\begin{array}{c}\text { Disagree with } \\
\begin{array}{c}\text { Statement } \\
(n=1756)\end{array}\end{array}$ & $\begin{array}{c}\text { Agree with } \\
\text { Statement } \\
(n=319)\end{array}$ \\
\hline $\begin{array}{c}90 \% \\
10\end{array}$ & $\begin{array}{c}80 \% \\
20\end{array}$
\end{tabular}

$(n=1999)$

Disagree with Agree with Statement Statement

$(n=1705) \quad(n=294)$

$26 \%$

$36 \%$

74

64

\begin{tabular}{lccc} 
& \multicolumn{2}{c}{$(n=2027)$} \\
\cline { 2 - 2 } Prefer Cash Now & $\begin{array}{c}\text { Disagree with } \\
\text { Statement } \\
(n=1718)\end{array}$ & $\begin{array}{c}\text { Agree with } \\
\text { Statement } \\
(n=309)\end{array}$ \\
Prefer Saving for a Future Purchase & $73 \%$ & $\frac{69 \%}{67}$ & 31
\end{tabular}

No significance.

(a) Represented by agreement or disagreement with the following statement: "I pretty much spend for today and let tomorrow bring what it will" (Question 174). 
Similarly, they were also more likely to prefer monthly installments over saving for a future purchase (36\% versus $26 \%$ ).

\subsection{DISCUSSION}

In this chapter, we found that, with respect to energy conservation investments made during 1983-85, the most important funding sources were current income and savings. These two sources together were mentioned by over $80 \%$ of the respondents as contributing the highest proportion of funds. Loans was third, mentioned by about $10 \%$ of the respondents. In contrast, the most important sources perceived for potential future investment were loans from banks, family and a utility. Together, they were mentioned by about half of the respondents. The second most important source of potential future conservation investment was utility payment.

There are several possible explanations for the above findings. First, consumers may have exhausted their savings or reached the limit of their current income. Hence, they have to place heavier reliance on loans. Second, homeowners may have had a greater awareness of the residential weatherization programs operated by electric utilities and expect that utilities would subsidize them in installing ECMs. Third, homeowners may have so far spent on items requiring relatively small amounts of expenses which can be met by savings and current income. In the future, items requiring substantial sums are being considered and loans and financing are necessary. Finally, the consumers might want to preserve cash and current income for other spending. As a result, they indicated that they would rely more heavily on loans and payment by a utility. Whatever the explanation, the implication is that, if it is desirable to keep ECM installations at the level realized in the past two years, it is necessary to maintain programs such as the residential weatherization program, which help pay for a substantial part of total costs of ECM installations. In addition, programs that would permit ready access to bank and utility loans may need to be developed or promoted.

The consumers' first choice of three different ways of paying for the purchases of major consumer products was to pay cash now. The second choice was to save first for a future purchase. The third and last choice was paying by 
monthly installments. This finding suggests a relative aversion to incur debt. It is consistent with the finding on the funding sources of conservation investment made during 1983-85. It contradicts the finding on funding sources of potential future conservation investment. This may suggest that the motivation for investing in energy conservation measures is weaker than that for purchases of major consumer products. Thus, the finding on future funding sources appears even more remarkable and deserves further investigation. If it could be confirmed by other data, future conservation program design could become more effective by considering the finding on funding sources for future conservation investments.

Respondents with income less than $\$ 16,000$ preferred saving first over monthly installments. Since this income group's ability to save may be limited, their funding preference may mean long delays in installing ECMs. To promote installations of ECMs by homeowners in this income group, financial assistance such as that offered in the low income weatherization programs may be necessary. 


\subsection{DEMOGRAPHIC AND PSYCHOGRAPHIC INFLUENCES ON CONSERVATION FINANCING}

This chapter discusses the demographic and psychographic variables that may affect the manner in which past and potential future energy conservation investments in the home are financed. The hypothesis that there are no differences in terms of demographics and psychographics between consumer groups who finance with loans, current income, savings and other sources (Hypothesis No. 1) is tested with contingency table analysis. The categories of conservation financing used in this analysis are explained first. Demographic, psychographic and attitudinal factors are then treated in sequence. Finally, findings and implications are discussed.

\subsection{CATEGORIES OF CONSERVATION FINANCING}

Reported sources of past and potential future conservation investment financing were detailed in Section 3.1 above. Since the hypothesis to be tested states that there are no differences in terms of demographics and psychographics between consumer groups who finance with loans, current income, savings, and other sources, it is necessary to regroup the financing sources described in the previous chapter into the four broader categories required by the hypothesis: loans, current income, savings, and other sources.

For this purpose, the category of loans included loans from banks, credit unions, the local utility, and the respondent's family or friends. The category of current income included also cutting back or delaying other purchases. Saving was in a separate category from current income because it did not involve sacrifice of current purchases or change of lifestyles. The category of "other sources" included federal tax credits, payments by utility, payments by others, combined sources, and other miscellaneous funding sources.

In terms of the financing sources for past investments, the classification of financing categories was based on Question 150 in the survey instrument. The classification for future financing sources was based on Question 151.(a)

(a) See Section 3.1 for the citation of Questions 150 and 151. 
Table 4.1 presents the financing sources for both past investments and potential new investments based upon these four categories.

For all homeowners as well as owners of homes with electric heat, current income financed the largest share (65\%) of past conservation investments, but accounted for only about $12 \%$ of potential future investments. In contrast, about half of the respondents indicated that they would finance future installation of energy conservation measures with loans, compared to only about $10 \%$ for past investments. Saving was second in financing past investment with 19\%, but accounted for only about $9 \%$ in potential future investment. In potential future investments, over one quarter $(29 \%$ and $34 \%$, respectively, for all homes and electric heat homes) would be financed through the "other sources" category. The other sources category included the "payment by utility" which accounted for over $26 \%$. (a)

\subsection{DEMOGRAPHIC INFLUENCES ON PAST AND FUTURE CONSERVATION FINANCING}

In the following analyses, the null hypothesis is that a demographic variable such as education has no impact on past financing practices. Demographic variables tested include gender, age, education, income,

TABLE 4.1. Categories of Conservation Financing Sources

\begin{tabular}{|c|c|c|c|c|}
\hline \multirow[b]{3}{*}{$\begin{array}{l}\text { Category } \\
\text { of Financing } \\
\text { Sources }\end{array}$} & \multicolumn{4}{|c|}{ Number of Homeowners (in 1000s) } \\
\hline & \multicolumn{2}{|c|}{ A11 } & \multicolumn{2}{|c|}{ Electric Heat (a) } \\
\hline & $\begin{array}{c}\text { Investments Made } \\
\text { During 1983-1985 } \\
(\mathrm{n}=1755) \\
\end{array}$ & $\begin{array}{l}\text { Potential } \\
\text { Future } \\
\text { Investments } \\
(n=1531) \\
\end{array}$ & $\begin{array}{c}\text { Investments Made } \\
\text { During 1983-1985 } \\
(n=995)\end{array}$ & $\begin{array}{l}\text { Potential } \\
\text { Future } \\
\text { Investments } \\
(n=903) \\
\end{array}$ \\
\hline Loans & $10 \%$ & $50 \%$ & $9 \%$ & $49 \%$ \\
\hline Current Income & 65 & 12 & 65 & 10 \\
\hline Savings & 19 & 9 & 18 & 7 \\
\hline Other Sources & 6 & 29 & 8 & 34 \\
\hline
\end{tabular}

(a) Electricity is the primary or secondary heating fuel.

(a) Table 3.2 for this information. 
occupation, household size, race, whether there is a householder working for the local electric utility, type of the local electric utility, type of residence, the identity of the investment decision maker, and the category of investment made in the past two years. Many of the tests were not statistically significant; others could not be tested because of the limited sample sizes of sub-grouping based on the variable concerned. The following first explains those variables that yielded significant results for either past financing practices or potential future practices: age, education, household size, the investment categories based upon the amount of investment, and type of heating fuels. The variables with no significant impacts, and for which tests could not be conducted, are then briefly mentioned, with the statistical tables of these factors shown in Appendix $A$.

\subsubsection{Age}

The test on the influence of respondent age on financing sources of conservation investment yielded mixed results. On the one hand, the data on financing sources of investment made during 1983-85 suggests that age of the respondents was not a determinant of conservation financing source (Table 4.2). On the other hand, the data on future financing indicates that those respondents who were under 54 years old were more likely to finance with loans or other sources than current income and savings, and were less likely to finance with current income or savings, than were those who were over 55 years old (Table 4.3). For example, 51\% of those who were under 34 years of age and $54 \%$ of those who were between 35 and 54 years old would finance their future conservation investments with loans, compared to only $44 \%$ of those who are over 55 years of age. In contrast, while only $7 \%$ of respondents who were in the youngest age group would finance potential future investment with current income, about $19 \%$ of those who were over 55 years old would do so. 
TABLE 4.2. Financing Sources of Conservation Investment During 1983-85 by Age

\begin{tabular}{|c|c|c|c|}
\hline \multirow[b]{2}{*}{$\begin{array}{l}\text { Respondents who } \\
\text { Financed with }\end{array}$} & \multicolumn{3}{|c|}{$\begin{array}{c}\text { Number of Homeowners (in 1000s) } \\
\text { Age }(n=1724)\end{array}$} \\
\hline & $\begin{array}{l}\text { Under } 34 \\
(n=411)\end{array}$ & $\begin{array}{r}35-54 \\
(n=759) \\
\end{array}$ & $\begin{array}{l}\text { Over } 55 \\
(n=554) \\
\end{array}$ \\
\hline Loans & $13 \%$ & $11 \%$ & $7 \%$ \\
\hline Current Income & 66 & 63 & 65 \\
\hline Savings & 14 & 18 & 23 \\
\hline Other Sources & 8 & 7 & 4 \\
\hline
\end{tabular}

TABLE 4.3. Financing Sources of Potential Future Conservation Investment by Age

\begin{tabular}{|c|c|c|c|}
\hline \multirow[b]{2}{*}{$\begin{array}{l}\text { Respondents Who } \\
\text { Would Finance With }\end{array}$} & \multicolumn{3}{|c|}{$\begin{array}{c}\text { Number of Homeowners (in 1000s) } \\
\text { Age }(n=1503)\end{array}$} \\
\hline & $\begin{array}{l}\text { Under } 34 \\
(\mathrm{n}=352) \\
\end{array}$ & $\begin{array}{r}35-54 \\
(n=734) \\
\end{array}$ & $\begin{array}{l}\text { Over } 55 \\
(n=417) \\
\end{array}$ \\
\hline Loans & $51 \%$ & $54 \%$ & $44 \%$ \\
\hline Current Income & 7 & 10 & 19 \\
\hline Savings & 7 & 8 & 13 \\
\hline Other Sources & 36 & 28 & 24 \\
\hline
\end{tabular}

\subsubsection{Education}

The educational level of the household appeared to have affected how conservation investments made between November 1983 through October 1985 were financed but did not influence the expected sources of financing for potential future conservation investments (Table 4.4 and 4.5). Households with at most a high school education were more likely than are those with some college or more to want to have financed past conservation investments with current income and were less likely to have done so with loans. 
TABLE 4.4. Financing Sources of Conservation Investment During 1983-85 by Education Level of the Household

Number of Homeowners (in 1000s)

\begin{tabular}{|c|c|c|c|c|}
\hline \multirow[b]{2}{*}{$\begin{array}{l}\text { Respondents Who } \\
\text { Financed with }\end{array}$} & \multicolumn{4}{|c|}{$\begin{array}{l}\text { Number of Homeowners (in 1000s) } \\
\text { at ion Level of the Household }(n=1748)\end{array}$} \\
\hline & $\begin{array}{c}\text { Completed } \\
\text { High School } \\
\text { or Less } \\
(n=615) \\
\end{array}$ & $\begin{array}{l}\text { Some } \\
\text { Col lege } \\
(n=454) \\
\end{array}$ & $\begin{array}{l}\text { Completed } \\
\text { College or } \\
\text { Trade/Votech } \\
(n=436) \\
\end{array}$ & $\begin{array}{l}\text { At Least } \\
\text { Some Grad } \\
\text { School } \\
(n=243) \\
\end{array}$ \\
\hline Loans & $7 \%$ & $15 \%$ & $8 \%$ & $14 \%$ \\
\hline Current Income & 70 & 55 & 66 & 66 \\
\hline Savings & 17 & 24 & 21 & 12 \\
\hline Other Sources & 6 & 6 & 5 & 9 \\
\hline
\end{tabular}

TABLE 4.5. Financing Sources of Potential Future Conservation Investment by Education Level of the Household

Number of Homeowners (in 10000s)

\begin{tabular}{|c|c|c|c|c|}
\hline \multirow[b]{2}{*}{$\begin{array}{l}\text { Respondents Who } \\
\text { Would Finance with }\end{array}$} & \multicolumn{4}{|c|}{$\begin{array}{l}\text { Number of Homeowners (in } 10000 \mathrm{~s}) \\
\text { ation Level of the Household }(n=1524)\end{array}$} \\
\hline & $\begin{array}{c}\text { Completed } \\
\text { High School } \\
\text { or Less } \\
(n=502) \\
\end{array}$ & $\begin{array}{c}\text { Some } \\
\text { Col lege } \\
(n=387) \\
\end{array}$ & $\begin{array}{l}\text { Completed } \\
\text { College or } \\
\text { Trade/Votech } \\
(n=409) \\
\end{array}$ & $\begin{array}{l}\text { At Least } \\
\text { Some Grad } \\
\text { School } \\
(n=226) \\
\end{array}$ \\
\hline Loans & $52 \%$ & $52 \%$ & $49 \%$ & $43 \%$ \\
\hline Current Income & 14 & 10 & 12 & 15 \\
\hline Savings & 6 & 7 & 15 & 8 \\
\hline Other Sources & 28 & 31 & 24 & 33 \\
\hline
\end{tabular}

No significance.

\subsubsection{Household Size}

The number of people in the household appeared to affect the choice of financing methods for energy conservation investments made during 1983-85. Larger households were more likely to finance with loans and less likely to finance with savings than were smaller households. For instances, $25 \%$ of those households with 5 members and 15\% of those with 4 members would finance with loans. These can be compared with $5 \%$ and $7 \%$, respectively, for the 1-person or 2-person households. In contrast, about $14 \%$ of the 4 - or 5-person households 
financed their past investments with savings, compared with $32 \%$ for the 1-person households and 19\% for the 2-person households. Note that households with 6 persons or more did not appear to follow the above generalization (Table 4.6).

Table 4.7 suggests the relationship between household size and future financing sources of potential conservation investments was statistically not quite significant at the $5 \%$ level.

TABLE 4.6. Financing Sources of Conservation Investment During 1983-85 by Household Size

\begin{tabular}{|c|c|c|c|c|c|c|}
\hline \multirow[b]{2}{*}{$\begin{array}{l}\text { Respondents Who } \\
\text { Financed With }\end{array}$} & \multicolumn{6}{|c|}{$\begin{array}{l}\text { Number of Homeowners (in 1000s) } \\
\text { Number of People in Household } \quad(n=1755)\end{array}$} \\
\hline & $\begin{array}{c}1 \\
(n=227) \\
\end{array}$ & $\begin{array}{l}2 \\
(n=607) \\
\end{array}$ & $\begin{array}{l}3 \\
(n=314) \\
\end{array}$ & $\begin{array}{c}4 \\
(n=352) \\
\end{array}$ & $\begin{array}{l}5 \\
(n=147) \\
\end{array}$ & $\begin{array}{l}6 \\
(n=107)\end{array}$ \\
\hline Loans & $5 \%$ & $7 \%$ & $8 \%$ & $15 \%$ & $25 \%$ & $12 \%$ \\
\hline Current Income & 59 & 69 & 65 & 65 & 50 & 67 \\
\hline Savings & 32 & 19 & 19 & 13 & 12 & 19 \\
\hline Other Sources & 4 & 4 & 8 & 7 & 14 & 2 \\
\hline
\end{tabular}

TABLE 4.7. Financing Sources of Potential Future Conservation Investment by Household Size

Number of Homeowners (in 1000s)

Number of People in Household $(n=1531)$

\begin{tabular}{|c|c|c|c|c|c|c|}
\hline $\begin{array}{l}\text { Respondents Who } \\
\text { Financed With }\end{array}$ & $\begin{array}{c}1 \\
(n=204) \\
\end{array}$ & $\begin{array}{c}2 \\
(n=495)\end{array}$ & $\begin{array}{c}3 \\
(n=280) \\
\end{array}$ & $\begin{array}{c}4 \\
(n=319) \\
\end{array}$ & $\begin{array}{c}5 \\
(n=139) \\
\end{array}$ & $\begin{array}{c}6 \\
(n=94) \\
\end{array}$ \\
\hline Loans & $55 \%$ & $41 \%$ & $56 \%$ & $52 \%$ & $56 \%$ & $49 \%$ \\
\hline Cash/Current Income & 21 & 12 & 8 & 12 & 9 & 13 \\
\hline Savings & 9 & 11 & 11 & 4 & 9 & 10 \\
\hline Other Sources & 15 & 36 & 24 & 32 & 27 & 27 \\
\hline
\end{tabular}

$x^{2}=24.886, P=0.051$. 


\subsubsection{Amount of Past Conservation Investment}

For analysis purposes, the amount of conservation investments made during 1983-85 can be grouped into five categories: $\$ 0, \$ 1$ to $\$ 500, \$ 501$ to $\$ 1000$, $\$ 1001$ to $\$ 2000$, and over $\$ 2000$. Table 4.8 indicates that sources of financing were affected by the amount of the investment: the larger the investment made, the more likely was it to be financed with loans, and the less likely was it to be financed with current income or other sources. For example, $21 \%$ of those households with an investment of $\$ 2000$ or more financed their investment with loans, compared with $13 \%$ for those with an investment in the $\$ 1001$ to $\$ 2000$ category, $7 \%$ for those with an investment in the $\$ 501$ to $\$ 1000$ category, and $4 \%$ for those with an investment of $\$ 1-\$ 500$. On the other hand $57 \%$ of the highinvestment households financed their investments by current income, compared to $68 \%$ of those in the low-investment category.

\subsubsection{Electric Heat}

When homes with electricity as the primary or secondary hating fuels are considered as an electric heat group, they can be compared with homes in the nonelectric heat group. Table 4.9 indicates that the financing sources of past conservation investment are not affected by the type of heating fuel considered. In contrast, Table 4.10 suggests that there were significant differences in financing potential future investments. Owners of homes with electric heat were more likely than owners of nonelectric homes to be inclined to fund

TABLE 4.8. Financing Sources of Conservation Investment During 1983-85 by Amount Invested in Conservation Over the Past Two Years

$$
\text { Number of Homeowners (in 1000s) }
$$

Respondents Who

Financed With

Loans

Current Income

Savings

Other Sources

\begin{tabular}{cc}
$\begin{array}{c}\text { Amo } \\
(n=185)\end{array}$ & $\begin{array}{l}\$ 1-500 \\
(n=430)\end{array}$ \\
\hline $4 \%$ & $\frac{4 \%}{4 \%}$
\end{tabular}

68

14

14
68

17

11

Amounts Invested $(n=1119)$

$x^{2}=31.381, P=0.002$. 
TABLE 4.9. Financing Sources of Conservation Investment During 1983-85 by Electric Heat and Nonelectric Heat

\begin{tabular}{lcc} 
& \multicolumn{2}{c}{$\begin{array}{c}\text { Number of Homeowners (in 1000s) } \\
\text { Heating Fuel }\end{array}$} \\
$\begin{array}{l}\text { Respondents who } \\
\text { Financed with }\end{array}$ & $\frac{\begin{array}{c}\text { Electric Heat } \\
(n=995)\end{array}}{n}$ & $\begin{array}{c}\text { Nonelectric Heat } \\
(n=760)\end{array}$ \\
\hline Loans & 65 & $12 \%$ \\
Current Income & 18 & 64 \\
Savings & 8 & 20 \\
Other Sources & & 4 \\
No significance. & &
\end{tabular}

TABLE 4.10. Financing Sources of Potential Future Construction Investment by Electric Heat and Nonelectric Heat

\begin{tabular}{|c|c|c|}
\hline \multirow[b]{2}{*}{$\begin{array}{l}\text { Respondents Who } \\
\text { Would Finance With }\end{array}$} & \multicolumn{2}{|c|}{$\begin{array}{c}\text { Number of Homeowners (in 1000s) } \\
\text { Heating Fuel }(n=1531)\end{array}$} \\
\hline & $\begin{array}{l}\text { ETectric Heat } \\
(n=903) \\
\end{array}$ & $\begin{array}{c}\text { Nonelectric Heat } \\
(n=628)\end{array}$ \\
\hline Loans & $49 \%$ & $51 \%$ \\
\hline Current Income & 10 & 17 \\
\hline Savings & 7 & 11 \\
\hline Other Sources & 34 & 21 \\
\hline
\end{tabular}

potential future conservation investments with "other sources" (which include payment by the utility), $34 \%$ versus $21 \%$. Homeowners with electric heat were less likely to finance with current income, $10 \%$ compared with $17 \%$ for homeowners with nonelectric heat.

\subsubsection{Factors with No Significant Impacts}

Several of the demographic variables considered showed no significant impacts on the sources of financing past or potential future conservation investments. These include the gender of the respondent, the income of the household, occupations of the respondent and second householder, whether the electric utility serving the respondent was investor-owned or publicly-owned, 
or whether decisions on investing in ECMs are made by the respondent, second households, or shared. Appendix Tables A.1 through A.12 present the data for this group of demographic variables.

\subsubsection{Factors for Which the Test Cannot Be Conducted}

Because of the small sample size of the relevant subgroupings, the Chisquare test cannot be conducted for three of the demographic variables considered: race of the respondent, type of residence, and whether or not there was a householder who worked for an electric utility. The limiting sample sizes were 21 and 15 for race of the respondents for past investment and potential future investment, respectively; 2 and 4 by type of residence; 16 and 17 for working for an electric utility. Appendix Tables A.13 through A.18 present the underlying data for these factors.

\subsection{PSYCHOGRAPHIC INFLUENCES ON PAST AND FUTURE CONSERVATION FINANCING}

Psychographical and attitudinal factors considered in this report included reasons for using credit cards, preferences in financing the purchase of major consumer products, respondent's views on energy use and conservation expressed in terms of agreement or disagreement with 15 statements, and other views and perceptions. The following discussion treats these factors in sequence. In explaining the impacts of respondents' view on energy use and conservation, those statements with significant results are discussed first. Those which showed no significant results or those for which the test could not be conducted are then briefly noted, with supporting tables presented in Appendix $A$.

\subsubsection{Reasons for Using Credit Cards}

There appeared to be some indications that, compared to other groups, a larger proportion of those who indicated that they would use a credit card for installment payments had financed the conservation investments made during 1983-85 with current income (32\% versus $13 \%$ or less, Table 4.11 and Table 4.12). In terms of potential future financing, a larger proportion of those who indicated that they would use credit cards for installment payments 
TABLE 4.11. Financing Sources of Conservation Investment During 1983-85 by Use of Credit Cards

\begin{tabular}{|c|c|c|c|c|}
\hline \multirow[b]{2}{*}{$\begin{array}{l}\text { Respondents Who } \\
\text { Financed With }\end{array}$} & \multicolumn{4}{|c|}{$\begin{array}{l}\text { Number of Homeowners (in 1000s) } \\
\text { Reason for Using Credit Cards }(n=1193)\end{array}$} \\
\hline & $\begin{array}{l}\text { Installment } \\
\text { Payments } \\
(n=56) \\
\end{array}$ & $\begin{array}{l}\text { Convenience/ } \\
\text { Dislike } \\
\text { Carrying Cash } \\
(n=770) \\
\end{array}$ & $\begin{array}{l}\text { Never Have Cash/ } \\
\text { Buy Things Other- } \\
\text { wise Couldn't } \\
(n=305)\end{array}$ & $\begin{array}{l}\text { Other } \\
(n=62)\end{array}$ \\
\hline Loans & $13 \%$ & $9 \%$ & $14 \%$ & $8 \%$ \\
\hline Current Income & 75 & 62 & 67 & 66 \\
\hline Savings & 6 & 22 & 15 & 20 \\
\hline Other Sources & 7 & 7 & 4 & 6 \\
\hline
\end{tabular}

Statistical test could not be done.

TABLE 4.12. Financing Sources of Potential Future Conservation Investment by Use of Credit Cards

\begin{tabular}{|c|c|c|c|c|}
\hline \multirow[b]{2}{*}{$\begin{array}{l}\text { Respondents Who } \\
\text { Would Finance With }\end{array}$} & \multicolumn{4}{|c|}{$\begin{array}{l}\text { Number of Homeowners (in 1000s) } \\
\text { Reason for Using Credit Cards }(n=1074)\end{array}$} \\
\hline & $\begin{array}{c}\text { Installment } \\
\text { Payments } \\
(n=41) \\
\end{array}$ & $\begin{array}{c}\text { Conveniencel } \\
\text { Dislike } \\
\text { Carrying Cash } \\
(n=713) \\
\end{array}$ & $\begin{array}{l}\text { Never Have Cash/ } \\
\text { Buy Things Other- } \\
\text { wise Couldn't } \\
(n=279)\end{array}$ & $\begin{array}{l}\text { Other } \\
(n=41)\end{array}$ \\
\hline Loans & $38 \%$ & $47 \%$ & $65 \%$ & $42 \%$ \\
\hline Current Income & 32 & 13 & 7 & 5 \\
\hline Savings & 5 & 13 & 2 & 5 \\
\hline Other Sources & 25 & 27 & 26 & 48 \\
\hline
\end{tabular}

Statistical test could not be done.

will finance potential future installation of ECMs with current income. However, the statistical test could not be conducted because of the limiting size of the subsamples.

\subsubsection{Financing Preferences}

It appeared that those who preferred paying cash over monthly installments were less likely than those who preferred otherwise to have financed their past conservation investment with current income, and more likely to have used 
savings. For example, $63 \%$ of those who preferred paying cash now financed with current income and $20 \%$ financed with savings, compared to $74 \%$ and $9 \%$, respectively, of those who preferred installment payments (Table 4.13). However, there were no differences in the proportions financing with loans. There was no significant difference in the proportions of those who preferred paying cash now over paying by installments to finance their potential future investment (Table 4.14).

As can be expected, compared to those who preferred saving first, those who preferred installment payments were more likely to finance with loans, and less likely to finance with savings. For example, $15 \%$ of those who preferred

TABLE 4.13. Financing Sources of Conservation Investment During 1983-85 by Preference in Financing: Paying Cash Versus Installment Payment

\begin{tabular}{|c|c|c|}
\hline \multirow[b]{2}{*}{$\begin{array}{l}\text { Respondents Who } \\
\text { Financed With } \\
\end{array}$} & \multicolumn{2}{|c|}{$\begin{array}{c}\text { Number of Homeowners (in 1000s) } \\
\text { Preference }(n=1745)\end{array}$} \\
\hline & $\begin{array}{l}\text { Paying Cash } \\
(n=1533) \\
\end{array}$ & $\begin{array}{l}\text { Monthly Installment } \\
(n=212)\end{array}$ \\
\hline Loans & $10 \%$ & $9 \%$ \\
\hline Current Income & 63 & 74 \\
\hline Savings & 20 & 9 \\
\hline Other Sources & 6 & 8 \\
\hline
\end{tabular}

TABLE 4.14. Financing Sources of Potential Future Conservation Investment by Preference in Financing: Paying Cash Versus Installment Payments

\begin{tabular}{|c|c|c|}
\hline \multirow[b]{2}{*}{$\begin{array}{l}\text { Respondents Who } \\
\text { Would Finance With }\end{array}$} & \multicolumn{2}{|c|}{$\begin{array}{l}\text { Number of Homeowners (in 1000s) } \\
\text { Preference }(n=1517)\end{array}$} \\
\hline & $\begin{array}{l}\text { Paying Cash } \\
(n=1332)\end{array}$ & $\begin{array}{l}\text { Month1y Insta11ment } \\
(n=185)\end{array}$ \\
\hline Loans & $48 \%$ & $66 \%$ \\
\hline Current Income & 13 & 7 \\
\hline Savings & 9 & 4 \\
\hline Other Sources & 30 & 22 \\
\hline
\end{tabular}


monthly payments over saving first financed past investments with loans, compared to $9 \%$ of those who preferred otherwise. The proportion of those who financed past investment with savings are $15 \%$ for those who preferred monthly payments and $21 \%$ for those preferring saving first (Table 4.15 ). In terms of financing future investment, $59 \%$ of those who preferred monthly payments over saving first, compared to $48 \%$ of those who preferred saving first over monthly payments, would finance with loans. The corresponding proportions for financing with savings are $4 \%$ for those who preferred monthly payments and $11 \%$ for those who preferred saving first (Table 4.16).

Preference for paying cash now versus saving first for a future purchase had no impact on the financing sources of past conservation investments (Table 4.17). However, those who prefer paying cash were more likely than those who prefer saving first to use current income, $15 \%$ versus $5 \%$ (Table 4.18 ).

\subsubsection{Views on Energy Use and Conservation}

Among the 15 statements on energy use and conservation used to elicit agreement or disagreement by the respondents, only one showed significant results in the chi-square test. The statement is as follows: "Utilities should stop offering a variety of programs to encourage energy conservation." Close to 9 out of 10 homeowners $(87 \%)$ disagreed with this statement. Those who disagreed were less likely than those who agreed with this statement to finance

TABLE 4.15. Financing Sources of Conservation Investment During 1983-85 by Preference in Financing: Monthly Installment Versus Saving First

\begin{tabular}{|c|c|c|}
\hline \multirow[b]{2}{*}{$\begin{array}{l}\text { Respondents Who } \\
\text { Financed with } \\
\end{array}$} & \multicolumn{2}{|c|}{$\begin{array}{l}\text { Number of Homeowners } \\
\text { (in 1000s) } \\
\text { Preference }(n=1678)\end{array}$} \\
\hline & $\begin{array}{c}\text { Monthly } \\
\text { Installment } \\
(n=434) \\
\end{array}$ & $\begin{array}{l}\text { Saving } \\
\text { First } \\
(n=1244) \\
\end{array}$ \\
\hline Loans & $15 \%$ & $9 \%$ \\
\hline Current Income & 64 & 64 \\
\hline Savings & 15 & 21 \\
\hline Other Sources & 7 & 6 \\
\hline
\end{tabular}


TABLE 4.16. Financing Sources of Potential Future Conservation Investment by Preference in Financing: Monthly Installment Versus Saving First

Respondents Who Would Finance With

Loans

Current Income

Savings

Other Sources
Number of Homeowners (in 1000s)

Preference $(n=1475)$

$\begin{array}{cc}\begin{array}{c}\text { Monthly } \\ \text { Installment } \\ (n=431)\end{array} & \begin{array}{c}\text { Saving } \\ \text { First } \\ (n=1044)\end{array} \\ 59 \% & \frac{48 \%}{13 \%}\end{array}$

$\chi^{2}=8.199, P=0.042$

TABLE 4.17. Financing Sources of Conservation Investment During 1983-85 by Preference in Financing: Paying Cash Versus Saving First

\begin{tabular}{|c|c|c|}
\hline \multirow[b]{2}{*}{$\begin{array}{l}\text { Respondents Who } \\
\text { Financed With } \\
\end{array}$} & \multicolumn{2}{|c|}{$\begin{array}{l}\text { Number of Homeowners } \\
\text { (in } 1000 \text { s) } \\
\text { Preference }(n=1700)\end{array}$} \\
\hline & $\begin{array}{l}\text { Paying Cash } \\
(n=1218) \\
\end{array}$ & $\begin{array}{c}\text { Saving First } \\
(n=482)\end{array}$ \\
\hline Loans & $11 \%$ & $9 \%$ \\
\hline Current Income & 64 & 67 \\
\hline Savings & 20 & 17 \\
\hline Other Sources & 6 & 8 \\
\hline
\end{tabular}

their past conservation investment with current income (62\% versus $79 \%$ ), and more likely to have financed with loans (11\% versus $5 \%$ ), savings (19\% versus $14 \%$ ), or other sources (7\% versus $2 \%$ ) (Table 4.19$)$. It is possible that those who agreed with the statement are more likely to be those who are not eligible for participation in the residential weatherization programs. Hence, they had to rely more heavily on their own financial resources such as current income. As for future financing sources, there was no impact (Table 4.20). 
TABLE 4.18. Financing Sources of Potential Future Conservation Investment by Preference in Financing: Paying Cash Versus Saving First

\begin{tabular}{|c|c|c|}
\hline \multirow[b]{2}{*}{$\begin{array}{l}\text { Respondents Who } \\
\text { Would Finance With }\end{array}$} & \multicolumn{2}{|c|}{$\begin{array}{l}\text { Number of Homeowners } \\
\quad(\text { in } 1000 s) \\
\text { Preference }(n=1487)\end{array}$} \\
\hline & $\begin{array}{l}\text { Paying Cash } \\
(n=1085)\end{array}$ & $\begin{array}{c}\text { Saving First } \\
(n=402)\end{array}$ \\
\hline Loans & $49 \%$ & $52 \%$ \\
\hline Current Income & 15 & 5 \\
\hline Savings & 10 & 6 \\
\hline Other Sources & 26 & 36 \\
\hline
\end{tabular}

TABLE 4.19. Financing Sources of Conservation Investment During 1983-85 by Agreement or Disagreement with the Statement: "Utilities should stop offering a variety of programs to encourage energy conservation."

$\begin{array}{lcc} & \begin{array}{c}\text { Number of Homeowners } \\ (\text { in 1000s }) \\ (n=1690)\end{array} \\ \begin{array}{l}\text { Respondents Who } \\ \text { Financed With }\end{array} & \frac{\begin{array}{c}\text { Disagree } \\ (n=1470)\end{array}}{11 \%} & \begin{array}{c}\text { Agree } \\ (n=220)\end{array} \\ \text { Loans } & 62 & 79 \\ \text { Current Income } & 19 & 14 \\ \text { Savings } & 7 & 2 \\ \text { Other Sources } & & \\ & & \end{array}$

\subsubsection{Personal Perception and Use of Coupons}

Among other lifestyle statements used in the questionnaire, only two yielded significant results, one regarding the respondent's personal perception that he or she is in the "spending for today" category and the other whether the respondent regularly used coupons for shopping. Those respondents who agreed with the statement about "spending for today" were more likely than those who disagreed to finance past conservation investments with current 
TABLE 4.20. Financing Sources of Potential Future Conservation Investment by Agreement or Disagreement with the Statement: "Utilities should stop offering a variety of programs to encourage energy conservation."

\begin{tabular}{lcc}
$\begin{array}{c}\text { Respondents Who } \\
\text { Would Finance With }\end{array}$ & $\begin{array}{c}\text { Number of Homeowners } \\
\text { (in 1000s) } \\
(n=1477)\end{array}$ \\
\cline { 1 - 2 } Loans & $\begin{array}{c}\text { Disagree } \\
(n=1291)\end{array}$ & $\begin{array}{c}\text { Agree } \\
(n=185)\end{array}$ \\
Current Income & $49 \%$ & $57 \%$ \\
Savings & 9 & 13 \\
Other Sources & 30 & 9 \\
No significance. & & 21
\end{tabular}

income, $78 \%$ versus $62 \%$. They were also less likely to pay for investment with savings, $8 \%$ versus $21 \%$ (Table 4.21 ). There was no significant impact in terms of potential future financing (Table 4.22 ).

Table 4.23 indicates that the respondent's habit of using coupons when shopping had no impact on the financing sources of past conservation investments. However, Table 4.24 suggests there may be some minor impact for future

TABLE 4.21. Financing Sources of Conservation Investment During 1983-85 by Agreement or Disagreement with the Statement: "I pretty much spend for today and let tomorrow bring what it will."

\begin{tabular}{|c|c|c|}
\hline \multirow[b]{2}{*}{$\begin{array}{l}\text { Respondents Who } \\
\text { Financed With }\end{array}$} & \multicolumn{2}{|c|}{$\begin{array}{c}\text { Number of Homeowners } \\
(\text { in 1000s) } \\
(n=1713)\end{array}$} \\
\hline & $\begin{array}{l}\text { Disagree } \\
(n=1468)\end{array}$ & $\begin{array}{c}\text { Agree } \\
(n=245)\end{array}$ \\
\hline Loans & $11 \%$ & $8 \%$ \\
\hline Current Income & 62 & 78 \\
\hline Savings & 21 & 8 \\
\hline Other Sources & 6 & 6 \\
\hline
\end{tabular}


TABLE 4.22. Financing Sources of Potential Future Conservation Investment by Agreement or Disagreement with the Statement: "I pretty much spend for today and let tomorrow bring what it will."

\begin{tabular}{|c|c|c|}
\hline \multirow[b]{2}{*}{$\begin{array}{l}\text { Respondents Who } \\
\text { Would Finance With }\end{array}$} & \multicolumn{2}{|c|}{$\begin{array}{c}\text { Number of Homeowners } \\
(\text { in } 1000 s) \\
(n=1498)\end{array}$} \\
\hline & $\begin{array}{l}\text { Disagree } \\
(n=1304) \\
\end{array}$ & $\begin{array}{c}\text { Agree } \\
(n=194) \\
\end{array}$ \\
\hline Loans & $50 \%$ & $50 \%$ \\
\hline Current Income & 14 & 4 \\
\hline Savings & 9 & 7 \\
\hline Other Sources & 27 & 38 \\
\hline
\end{tabular}

TABLE 4.23. Financing Sources of Conservation Investment During 1984-85 by Agreement or Disagreement with the Statement: "I usually use coupons when I shop."

\begin{tabular}{lcc} 
& $\begin{array}{c}\text { Number of Homeowners } \\
(\text { in 1000s) } \\
(n=1667)\end{array}$ \\
$\begin{array}{l}\text { Respondents Who } \\
\text { Financed With }\end{array}$ & $\frac{\begin{array}{c}\text { Disagree } \\
(n=506)\end{array}}{13 \%}$ & $\begin{array}{c}\text { Agree } \\
(n=1161)\end{array}$ \\
\cline { 1 - 2 } Loans & 67 & 63 \\
Current Income & 15 & 21 \\
Savings & 6 & 6 \\
Other Sources & & \\
No significance. & &
\end{tabular}

investment financing. Those respondents who regularly used coupons were more inclined to finance future investments with loans than those who do not use coupons regularly, $51 \%$ versus $46 \%$. They were less likely to finance with current income than those who disagreed with the statement: $10 \%$ versus $19 \%$. 
TABLE 4.24. Financing Sources of Potential Future Conservation Investment by Agreement or Disagreement with the Statement: "I usually use coupons when I shop."

\begin{tabular}{|c|c|c|}
\hline \multirow[b]{2}{*}{$\begin{array}{l}\text { Respondents Who } \\
\text { Would Finance With }\end{array}$} & \multicolumn{2}{|c|}{$\begin{array}{l}\text { Number of Homeowners } \\
(\text { in } 1000 \mathrm{~s}) \\
(n=1468)\end{array}$} \\
\hline & $\begin{array}{l}\text { Disagree } \\
(n=438) \\
\end{array}$ & $\begin{array}{c}\text { Agree } \\
(n=1030)\end{array}$ \\
\hline Loans & 46 & 51 \\
\hline Current Income & 19 & 10 \\
\hline Savings & 10 & 8 \\
\hline Other Sources & 26 & 30 \\
\hline
\end{tabular}

4.3.5 Factors with No Significant Impacts (a)

Agreement or disagreement with the following statements related to energy use and conservation or to other views did not influence the financing of past or potential future conservation investments:

Question 173: The amount of energy I use is really my own affair and no one else's.

Question 175: I only use electricity when its really needed; there is no way I could cut down.

Question 176: I have already done everything I can to conserve energy. Question 177: I don't care if my clothes are unstylish as long as I like them.

Question 178: I consider myself a do-it-yourselfer.

Question 179: I consult consumer reports or similar publications before making major purchases.

(a) Tables supporting this section and the next section are shown in Appendix A Tables A.19 through A.52. 
Question 181: I will invest in improving the efficiency of my home only if there are rebates to me from the utility.

Question 184: It's silly to conserve electricity, because the utility just turns around and charges more for what you do use.

Question 186: My conservation efforts won't have much effect one way or the other on the availability of electricity.

Question 187: Conserving energy is the best way to protect the environment.

Question 188: It's our responsibility to conserve electricity for future generations.

Question 189: Conserving energy is the best way to maintain my lifestyle. Question 191: I would only make conservation improvements which would enhance the value of my home.

\subsubsection{Factors for Which the Test Cannot Be Conducted}

Due to limited sample size of subgroupings, the chi-square test for following statements could not be conducted:

Question 183: Electricity prices in the Northwest are not high enough to necessitate conservation.

Question 185: With the current power surplus in the Northwest, there is no need to conserve electricity.

Question 190: Most people who conserve electricity do so to save money. Question 192: I would invest in energy conservation measures because it increases the comfort of my home. 


\subsection{DISCUSSION}

Based on the above analysis, the following findings can be noted:

- Among demographic factors, age of respondents, education level of the household, household size, the amount of past investment, and electric heat exerted some impact on the financing sources of energy conservation investments.

- Compared to respondents who were over 55 years old, those who were under 55 years of age were more likely to finance potential future investments with loans and "other sources" and were less likely to finance with current income and savings.

- Households with at most a high school education were more likely than those with at least some college education to have financed past conservation investment with current income, and were less likely to have done so with loans.

- Larger households (with 4 or 5 members) were more likely to finance past investments with loans and less likely to finance with savings than were households with only 1 or 2 members.

- Respondents whose past investment was greater than $\$ 2000$ were more likely than those with less investment to finance with loans and are less likely to finance with current income or other sources.

- Owners of homes with electric heat were more likely than owners of nonelectric homes to be inclined to fund potential future conservation investment with "other sources" which included payment by the local utility and less likely to finance with current income. 
- Most of the attitudinal and psychographic variables did not affect the financing of past and potential future investments. However, preferences concerning the financing of major consumer products had significant influences. Views on whether utilities should offer programs to encourage energy conservation, views on the use of coupons when shopping, and the respondent's personal perception also influenced the financing sources.

- Respondents who preferred to finance the purchase of major consumer products with installment payments over saving first were more likely to finance both past and potential future investments with loans and less likely to finance with savings.

- Respondents who preferred paying cash now over installment payments were more likely to finance potential future conservation investment with current income, and were less likely to use "other sources."

- Those who agreed that utilities should stop offering programs to encourage energy conservation were more likely than those who disagreed to have financed their past conservation investments with current income, and were less likely to have financed with loans, savings, and other sources.

- Those who agreed with the statement that "I pretty much spend for today" were more likely than those who disagreed to finance past conservation investments with current income and were less likely to pay for such investments out of savings.

- Those who use coupons regularly while shopping were more likely than those who did not to finance future investments with loans. 
- Except for the variables noted above, the financing sources of conservation investments were not influenced by many of the demographic and psychographic variables. Therefore, it can be concluded that Hypothesis No. 1 is true to some extent, except for age, education, household size, the amount of investment, type of heating fuel, preferences concerning the financing of purchases of major consumer products, views on the role of utilities in promoting energy conservation, on use of coupons while shopping, and on living and spending for today.

Some of the implications of the above findings for designing and implementing conservation program can be briefly discussed. First, consumers who were under 55 years of age, with at least some college education, with a larger household, those who had invested more than $\$ 2,000$, and those with electric heat were more likely to finance their investment with loans. Hence, bank or utility loan programs to promote energy conservation by consumers may be targeted with these groups in mind. Similarly, to reach those who prefer to finance the purchase of major consumer products with installment payments rather than saving first, loan availability and "easy" installment payments may be featured in promotional programs. Furthermore, to increase participation of bank or utility loan programs for financing the installation of ECMs, promotion may be targeted at such market segments as those who disagreed with the statement that "utilities should stop offering programs to encourage energy conservation," and those who regularly used coupons while shopping. 


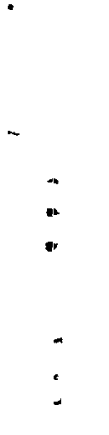




\subsection{INSTALLATION OF ENERGY CONSERVATION MEASURES AS HOME IMPROVEMENT}

Hypothes is No. 2 states that, other things being equal, those who view installation of conservation measures as home improvement will be willing to spend more than other groups of consumers on conservation. If the hypothesis were true, the consumers who viewed installations of ECMs as home improvements would have spent a larger amount of money during the 1983-85 period than did others who did not hold such a view. Similarly, in terms of likely future spending, those who hold such view would also be more likely to spend a larger amount. Since the individual consumer either holds the view or he doesn't, a dummy variable can be used to represent this perception. In addition, multiple regression allows for controlling for other relevant factors such as income or the number of ECMs installed. Therefore, regression analysis with dummy variables is appropriate for use to test the hypothesis.

This chapter presents the regression analyses performed to test the above hypothesis. The general approach used in the analysis is explained first. The specific approach, the variables, the data and the results are then discussed for investments made during 1984-85 and for potential future investments. A digression on the data on average conservation investments is also presented. Finally, the findings are summarized and implications explored.

\subsection{GENERAL APPROACH}

The general form of the regression equation in the analysis as follows:

$$
Y_{i}=a+\sum_{j} b_{j} \cdot x_{j i}+c \cdot z_{i}+\sum_{k} d_{k} \cdot w_{k i} \cdot
$$

where

$Y_{\mathfrak{i}}$ is the amount of conservation investment by respondent $i$;

$X_{j i}$ are potential determinants of conservation investment such as the number or type of ECMs involved, income of the respondent; 
$Z_{j}$ is the dummy variable to represent the view that installation of ECMs is home improvement. It is assigned the value of zero if the respondent does not hold such view and a value of 1 if he or she holds such view.

$W_{k i}$ are dummy variables representing other attitudes of the respondent.

$a, b_{j}, c$ and $d_{k}$ are coefficients to be estimated.

In this formulation, the hypothesis is tested by evaluating the significance of the coefficient $c$. Given the hypothesis as stated, $c$ is expected to be positive, indicating that, on the average, respondents who view installations of ECMs as home improvement will invest more by the amount of $\$ c$ above that of those who do not regard installation of ECMs as home improvements, after controlling for variables $x_{j}$ and $W_{k}$. If none of the possible definitions of $Z$ yielded any statistically significant value of $c$, then the null hypothesis, which states that viewing ECMs as home improvement does not matter, cannot be rejected. If $c$ is positive and statistically significant, then the null hypothesis is rejected and it can be concluded that those who view installation of conservation measures as home improvement will be willing to spend more than other groups of consumers on conservation.

\subsection{ANALYSIS BASED ON INVESTMENT MADE DURING 1983-85}

In the case of installation of ECMs made during the 1983-85, the specific equation to be estimated by regression is as follows:

\section{(MODEL 1)}

$$
\begin{aligned}
\text { INVEST }=a & +b_{1} \cdot \text { NECM }+b_{2} \cdot \text { INCOME }+b_{3} \cdot M E C M+c \cdot Z A \\
& +d_{1} \cdot \text { USE }+d_{2} \cdot \text { CONSERV }
\end{aligned}
$$

where INVEST = the amount of investment made during 1983-85;

$$
\text { NECM = the number of ECMS installed; }
$$




$$
\begin{aligned}
\text { INCOME = } & \text { household income; } \\
\text { MECM = } & \text { the number of ECMs already on the residence in 1983; } \\
Z A= & \text { the dummy variable representing the consumer's view concerning } \\
& \text { installation of ECMs defined in terms of Question } 191 \text { of the } \\
& \text { survey instrument. It will assume a value of } 1 \text { if the con- } \\
& \text { summer regarded installation of ECMs as home improvement and a } \\
& \text { value of } 0 \text { (zero) if otherwise. } \\
\text { USE = } & \text { a dummy variable representing consumer concern about energy } \\
& \text { use in the home; it assumes a value of } 1 \text { if the consumer was } \\
& \text { very concerned or somewhat concerned. } \\
\text { CONSERV = } & \text { a dummy variable representing consumer concern about energy } \\
& \text { conservation; it assumes a value of } 1 \text { if the consumer is } \\
& \text { very concerned or somewhat concerned. }
\end{aligned}
$$

Other things being equal, the larger the number of ECMs installed by the respondents during 1983-85, the larger the amount spent by the respondents. Similarly, the higher the income of the respondent, the larger the amount spent. Hence, coefficients $b_{1}$ and $b_{2}$ are expected to be positive. The number of ECMs already installed in 1983, (MECM), can be indicative of the need to install ECMs in the residence: the larger the MECM, the lower the need to install additional items. If it can be assumed that the lower the need to install additional ECMs, the smaller number of ECMs would be installed during 1983-85, and the smaller the investment made during the period, then coefficient $b_{3}$ can be expected to be negative. As discussed above, assuming Hypothesis No. 2 is true, coefficient $c$ can be expected to be positive. It might be assumed that those who were concerned about energy use in the home and energy conservation were more likely to spend on installing ECMs. Hence, coefficients $d_{1}$ and $d_{2}$ were assumed to be positive.

Variations of the above model can be derived by using different variables from the survey data to represent the ZA variable, by excluding some of the 
variables, or by combination of the above. In actual regression runs, an alternative way of defining the view on installation of ECMs as home improvement, ZC, was also used. Note that ZA and ZC do not appear on the same equation simultaneously.

\subsubsection{Data}

All the data used for the analysis were derived from the 1985 survey of Northwest consumer attitudes. The following provides a brief discussion of the nature of each of the variables involved.

INVEST was defined by combining the responses to Questions 143 and 146 . Question 143: "In the past two years, approximately how much money did you spend on reducing the amount of energy used in your home?" If the response to Question 143 indicates "none" but the consumer had previously responded yes to questions concerning installations of 12 different ECMs, then he or she is asked whether he or she personally spent any money on the installations. If yes, then Question 146 is asked: "What would you estimate that you personally spent on reducing the amount of energy used in your home?"

NECM is defined by enumerating the number of ECMs installed during the last two years in response to Questions $23,34,43,52,61,72,83,94,103$, 112, 121, and 130. Take Question 23 as an example: "How long ago was the weatherproofing installed? Was it (1) within the last two years, (2) longer than 2 years but since you've lived there, (3) there when you moved in?" The other questions deals respectively with storm windows, heat pump furnace, automatic or setback thermostat, basement or floor insulation, wall insulations, roof or ceiling insulation, solar panel for water heating, storm doors, heat pump water heater, wood stove/furnace, and fireplace insert.

INCOME is defined in terms responses to Questions 272, 273, and 274. Take Question 272 for example: "Is your total household income (1) under $\$ 5000$, (2) $\$ 5-\$ 7999,(3) \$ 8-\$ 9999,(4) \$ 10-\$ 11999,(5) \$ 12-\$ 13,999,(6) \$ 14-$ $\$ 15,999$." For analysis purposes, the mid-points of the income classes were used. 
MECM is defined by enumerating the responses indicating choices (2) or (3) to the same questions as used in defining the variable NECM. Note that NECM used choice (1).

ZA was assigned a value of 1 for those who strongly agreed or agreed with Question 191 and a value of 0 for those who strongly agreed, disagreed, or were neutral to Question 191: "I would only make conservation improvements which would enhance the value of my home."

ZC was an alternative variable for measuring the view that installations of ECMs are home improvements. ZC assumes a value of 1 if the respondent's expected benefit of installing a specific ECM was increased value of the home. ZC was constructed by observing whether "increased value of home" was indicated by the respondent when he or she was asked about the expected benefit of ECM installations in Questions $25,36,45,54,63,74,85,96,105,114,123$ and 132. As a example, Question 36: "What results did you expect after installation of storm windows? (1) save money, (2) reduce heating costs, (3) reduced energy consumption, (4) even room temperature throughout the home, (5) less household drafts, (6) conservation rebate, (7) more comfort, (8) increased value of home, (9) none, (55) other, specify..." Item (8) is the choice in question. Note that the choices were not read to the respondents in the interview process.

CONSERV and USE variables were dummy variables measuring the respondent's concern about energy conservation and energy use in the home. Each assumes a value of 1 if the respondent was very concerned or somewhat concerned about the issue. The data were based on Questions 4 and 11. Question 4: "Now I'm going to read you a short list of topics that some people are concerned about. Please tell me how you personally feel about each of these topics--would you say you are very concerned, somewhat concerned, not very concerned, or not at all concerned about energy conservation?" Question 11: "How about energy use in the home?"

\subsubsection{Regression Results}

Tables $5.1 \mathrm{a}$ and $5.1 \mathrm{~b}$ present the unweighted and weighted results of the various versions of regression equations estimated for Model 1, excluding the 
TABLE 5.1a. Unweighted Regression Results for Conservation Investments Made During 1983-85

Model 1. Dependent Varlable: INVEST

\begin{tabular}{|c|c|c|c|c|c|c|c|c|}
\hline \multirow[b]{2}{*}{ Equation } & \multicolumn{8}{|c|}{ Homeowners Only $(n=476)$} \\
\hline & (1) & (2) & (3) & (4) & (5) & $(6)$ & (7) & $(8)$ \\
\hline Intercept & $\begin{array}{l}-88.66 \\
(-0.365)\end{array}$ & $\begin{array}{l}-123.99 \\
(-0.548)\end{array}$ & $\begin{array}{l}30.25 \\
(0.091)\end{array}$ & $\begin{array}{r}-294.47 \\
(-0.699)\end{array}$ & $\begin{array}{l}-192.95 \\
(-0.432)\end{array}$ & $\begin{array}{l}14.01 \\
(0.043)\end{array}$ & $\begin{array}{l}-369.60 \\
(-0.907)\end{array}$ & $\begin{array}{l}-248.38 \\
(-0.572)\end{array}$ \\
\hline NECM & $\begin{array}{r}537.95^{* *} \\
(7.435)\end{array}$ & $\begin{array}{r}526.48^{* *} \\
(7.266)\end{array}$ & $\begin{array}{c}541.1^{* *} \\
(7.447)\end{array}$ & $\begin{array}{r}535.50^{* *} \\
(7.384)\end{array}$ & $\begin{array}{r}539.08^{* *} \\
(7.411)\end{array}$ & $\begin{array}{r}529.81^{* *} \\
(7.286)\end{array}$ & $\begin{array}{r}522.96^{* *} \\
(7.197)\end{array}$ & $\begin{array}{r}526.57^{* *} \\
(7.231)\end{array}$ \\
\hline INCOME & $\begin{array}{l}0.0266^{* *} \\
(3.915)\end{array}$ & $\begin{array}{l}0.0269^{* *} \\
(3.989)\end{array}$ & $\begin{array}{l}0.0263^{* *} \\
(3.857)\end{array}$ & $\begin{array}{l}0.0266^{* *} \\
(3.916)\end{array}$ & $\begin{array}{l}0.0263^{* *} \\
(3.844)\end{array}$ & $\begin{array}{l}0.0265^{* *} \\
(3.920)\end{array}$ & $\begin{array}{l}0.0269^{* *} \\
(3.986)\end{array}$ & $\begin{array}{l}0.0264^{* *} \\
(3.898)\end{array}$ \\
\hline$Z A$ & $\begin{array}{l}-98.71 \\
(-0.405)\end{array}$ & & $\begin{array}{l}-93.66 \\
(-0.384)\end{array}$ & $\begin{array}{l}-90.82 \\
(-0.372)\end{array}$ & $\begin{array}{l}-81.62 \\
(-0.333)\end{array}$ & & & \\
\hline $\mathrm{ZC}$ & & $\begin{array}{l}1886^{*} \\
(1.654)\end{array}$ & & & & $\begin{array}{r}1911.71^{*} \\
(1.674)\end{array}$ & $\begin{array}{l}1938.6^{*} \\
(1.696)\end{array}$ & $\begin{array}{r}1987.3^{*} \\
(1.735)\end{array}$ \\
\hline USE & & & $\begin{array}{l}-141.4 \\
(-0.525)\end{array}$ & & $\begin{array}{l}-192.67 \\
(-0.693)\end{array}$ & $\begin{array}{l}-161.68 \\
(-0.602)\end{array}$ & & $\begin{array}{l}-223.14 \\
(-0.805)\end{array}$ \\
\hline CONSERV & & & & $\begin{array}{l}224.52 \\
(0.598)\end{array}$ & $\begin{array}{c}290.52 \\
(0.750)\end{array}$ & & $\begin{array}{l}271.60 \\
(0.725)\end{array}$ & $\begin{array}{l}348.15 \\
(0.901)\end{array}$ \\
\hline $\mathrm{R}^{2}$ & 0.1340 & 0.1387 & 0.1387 & 0.1346 & 0.1355 & 0.1393 & 0.1396 & 0.1408 \\
\hline$R^{2}(\operatorname{Adj})$ & 0.1285 & 0.1332 & 0.1271 & 0.1273 & 0.1263 & 0.1320 & 0.1323 & 0.1317 \\
\hline$F$ & 24.343 & 25.333 & 18.298 & 18.322 & 14.737 & 19.064 & 19.112 & 15.408 \\
\hline Prob. $>F$ & 0.0001 & 0.0001 & 0.0001 & 0.0001 & 0.0001 & 0.0001 & 0.0001 & 0.0001 \\
\hline
\end{tabular}

Numbers In parentheses are t-values.

* Significant at the $5 \%$ ievel.

* Significant at the 18 level. 
TABLE 5.1b. Weighted Regression Results for Conservation Investments Made During 1983-85

Model 1. Dependent Varlable: INVEST

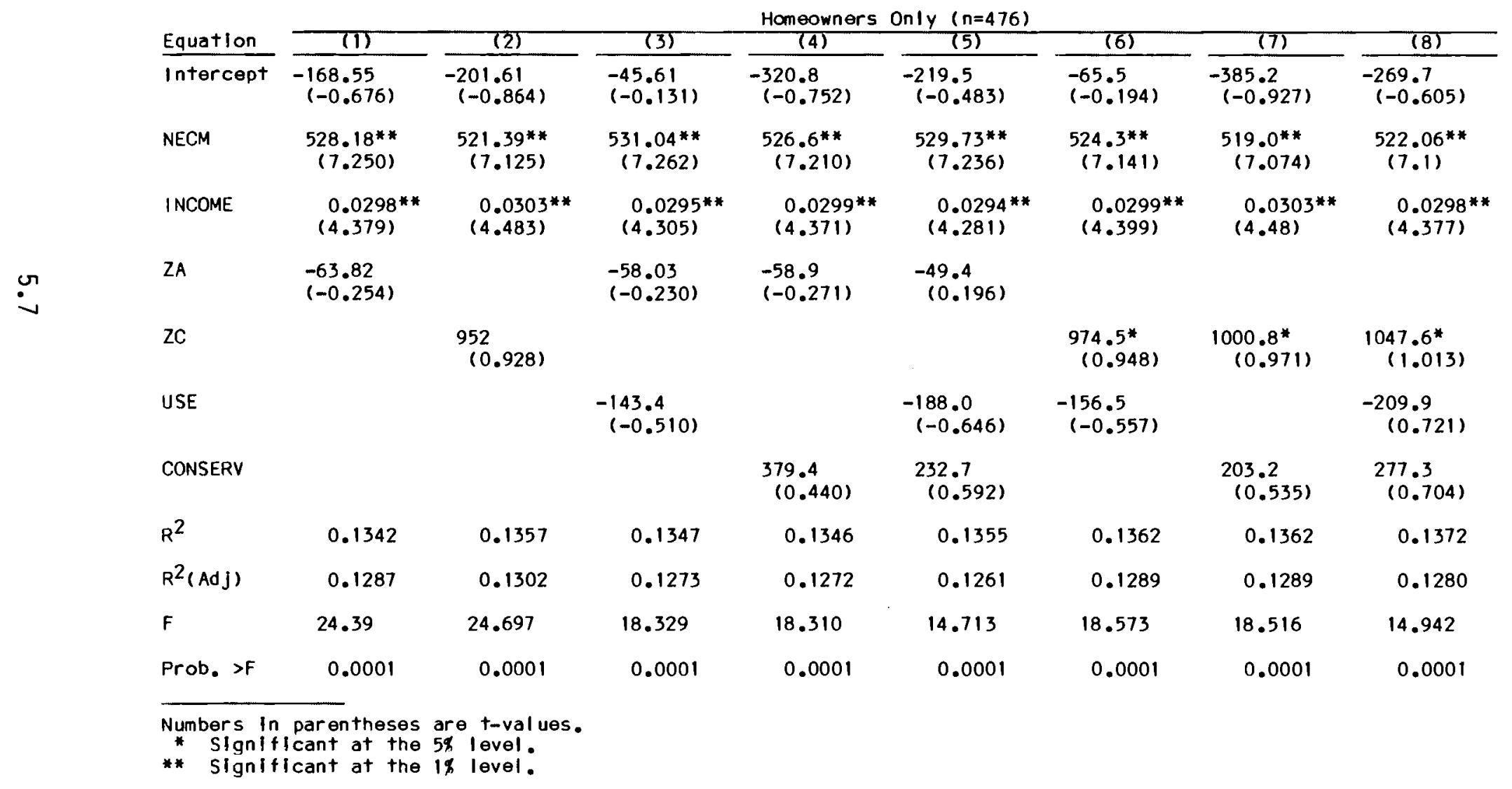


variable representing the number of energy conservation measures already in the house of the respondents at the end of 1983, (MECM). Tables 5.2a and 5.2b present similar unweighted and weighted regression equations estimated with the inclusion of MECM variable. The following discussion interprets the results contained in these two tables.

Although the regression equations are highly significant in terms of the F-test, the coefficients of determination, $R^{2} s$, are generally low. Only about $13 \%$ to $15 \%$ of the variations observed in past conservation investments by households in the Northwest are explained by the variables included in Model 1. Low $R^{2} s$ are generally expected in cross-sectional data of this type. Nevertheless, this result suggests that there are other variables that can be incorporated into the regression. The obvious ones are the types of ECMs installed by the individual households.

NECM, the number of ECMs installed during the 1983-85 period, has the expected sign and is highly significant. Estimates of its coefficient fall in the range of $\$ 620$ to $\$ 540$ in Tables $5.1 \mathrm{a}$ and $5.1 \mathrm{~b}$ and in the range of $\$ 620$ to $\$ 650$ in Tables $5.2 \mathrm{a}$ and $5.2 \mathrm{~b}$. This means that, on the average, adding one more ECM on the house during the $1983-85$ period would require additional spending in the range of $\$ 520$ to $\$ 650$. As noted above, there were a total of 12 ECMs included in the 1985 survey, ranging from installing automatic or setback thermostat and weatherproofing to installation of solar panels for water heating and heat pump furnace. The estimates of the coefficient for NECM is an average only.

The household income variable, INCOME, also has the expected sign and is highly significant. The parameter estimate falls in the range of 0.023 to 0.030 . This result suggests the marginal rate of investing in energy conservation is about $2.3 \%$ to $3.0 \%$. As household income increases by $\$ 1000$, the additional amount of money spent on installing energy conservation measures on their residences, averages about $\$ 23$ to $\$ 30$.

With the dummy variable representing the perception of installing ECMs as home improvement, the results are mixed. When variable $Z A$ is used, the estimate is not significant and has the wrong sign. When variable $Z C$ is used, the estimate has the expected sign and is significant at the $5 \%$ level. The 
TARLE 5.2a. Unweighted Regression Results for Conservation Investments Made During 1983-85, Including MECM

Model 1. Dependent Varlable: INVEST

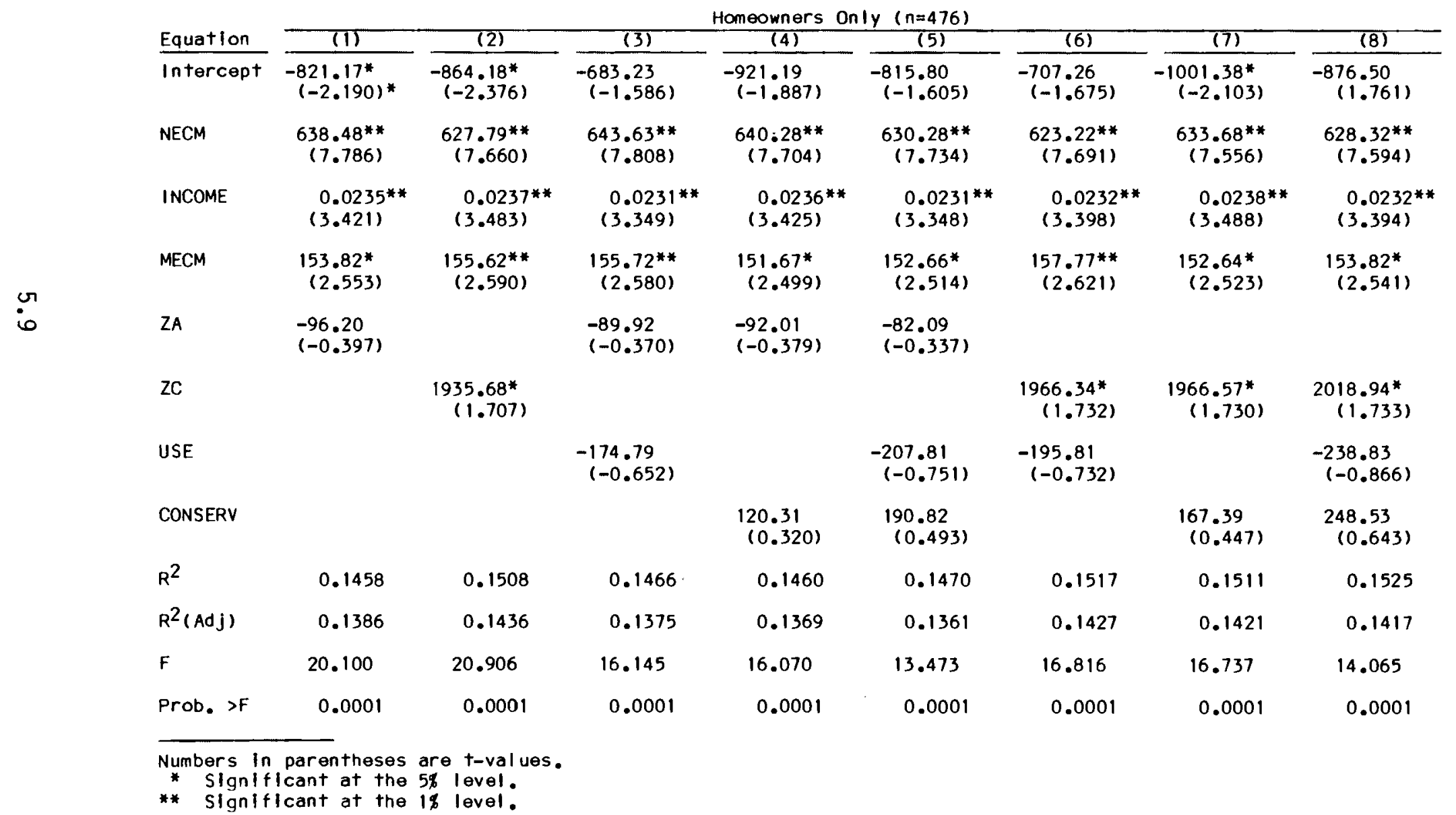


TABLE 5.2b. Weighted Regression Results for Conservation Investments Made During 1983-85, Including MECM

Model 1. Dependent Varlable: INVEST

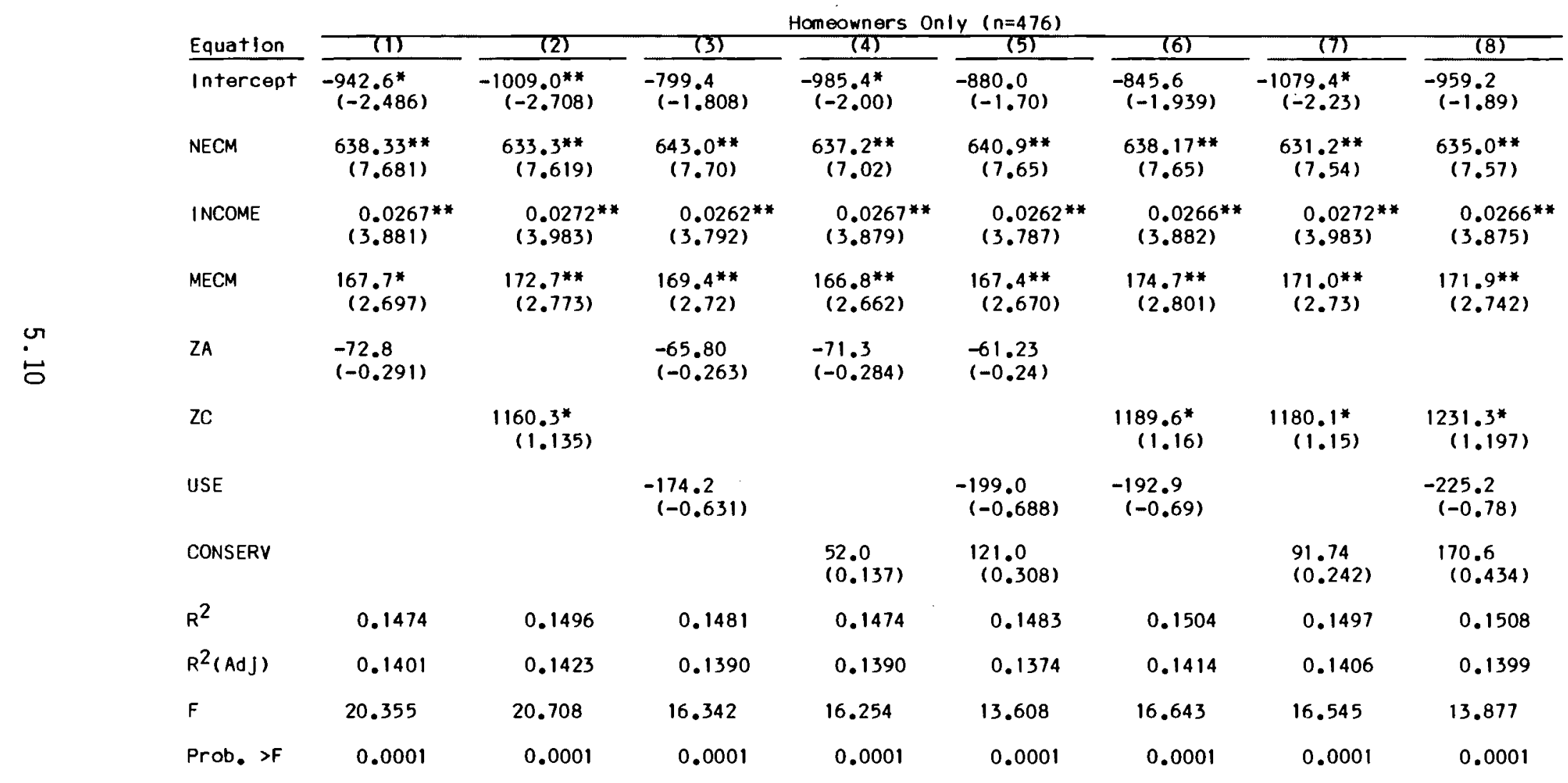

Numbers in parentheses are t-values.

* Significant at the $5 \%$ level.

* Slaniflcant at the is level. 
parameter estimate for ZC ranges from a low of $\$ 1886$ to a high of $\$ 2018$ in the unweighted results (Tables $5.1 \mathrm{a}$ and $5.2 \mathrm{a}$ ). This result suggests that, even after controlling for income and the numbers of ECMs installed, those who regarded installation of energy conservation measures as home improvement are likely to spend between about $\$ 1900$ and about $\$ 2000$ more than those who don't hold such view. Thus, Hypothesis No. 2 appears to be confirmed by this result. However, in the weighted regressions, variable $Z C$ becomes insignificant (Tables 5.1b and 5.2b).

At first glance, the unexpected results derived for variable $Z A$ is troubling, because it appears to contradict Hypothesis No. 2. Note ZA is intended to measure the view that installation of ECMs is home improvement. A closer look at the data underlying $Z A$ led to the conclusion that $Z A$, as constructed, was not a good variable for testing the hypothesis. ZA is derived from Question 191 of the survey instrument. Question 191 asked the respondents to express their agreement or disagreement with the statement, "I would only make conservation improvements which would enhance the value of my home." ZA was assigned a value of 1 if respondent agreed or strongly agreed with the statement, and a value of 0 otherwise. Hypothes is No. 2 requires a more positive definition of the attitude concerning installation of ECMs as home improvement; the respondent needs to be in agreement with a statement such as: "Personally, I would regard installing energy conservation measures as a home improvement." As explained above, the construction of variable $\mathrm{ZC}$ comes closer to this more appropriate statement than Question 191.

However, ZC suffered from the small number of observations; there were only a total of 6 observations among the total of 766 homeowners in the sample. It follows that a separate question asking whether the respondent regards installation of ECMs as home improvement needs to be incorporated into the survey instrument for future surveys if the same hypothesis is to be tested again.

The other two dummy variables, USE and CONSERV, were used to characterize the respondent's attitudes towards energy use in the home (USE) and energy conservation (CONSERV). The results for neither is significant, although they have different signs. This finding suggests that the amount of conservation 
investment made during 1983-85 are not affected by the consumers' concern about energy conservation or energy use in the home. Thus, in the context of Model 1, there is no need to segment those who are concerned about energy use in the home and energy conservation from those who are not concerned with the two issues.

As noted above, the number of ECMs already in the house, MECM, was introduced to measure the need for installations of ECMs made after 1983. It was expected to have a negative sign. The results tabulated in Tables 5.2a and $5.2 b$ indicate that the influence of MECM is positive and significant at either $5 \%$ or $1 \%$ level. Estimates of the coefficient fall in a very narrow range between $\$ 151$ and $\$ 175$, suggesting that, for one additional ECM already in the residence in the year 1983 , between $\$ 150$ and $\$ 175$ in additional conservation investment would have been made during 1983-85. Note, however, the introduction of the MECM variable, the number of ECMs already in the house in 1983, raises the explanatory power of the regression equations by only 1-2 percentage points, from about 0.14 to about 0.15 .

Note that weighting the regression according to the relative weights of the four geographical divisions of the Northwest did not make much difference in the values of the coefficient estimates. The only point worth mentioning is the fact that the coefficients of $Z C$ in Tables $5.1 b$ and $5.2 b$ become insignificant as a result. This result further limits the support of the current data to the hypothesis being tested.

\subsection{ANALYSIS BASED ON POTENTIAL FUTURE INVESTMENT}

In the case of potential future installations of ECMs, the following model was specified:

(MODEL 2)

$$
\begin{aligned}
\text { FINVEST }=a & +b_{1} \cdot \text { INCOME }+b_{2} \cdot \text { TECM } 1+b 3 \cdot \text { TECM2 }+b_{4} \cdot \text { TECM3 } \\
& +c \cdot 2 A+d_{1} \cdot \text { USE }+d_{2} \cdot \text { CONSERV, }
\end{aligned}
$$


where FINVEST = the maximum amount the respondent is willing to spend on the first ECM that he or she would install in the future;

TECM1 = a dummy variable to represent wood stove;

TECM2 = a dummy variable to represent "insulation and weatherization";

TECM3 = a dummy variable to represent "all other types of ECMs" except for wood stove, insulation and weatherization, and "installing solar".

Note that "installing solar" is the fourth category which will be further explained below in Section 5.3.1. INCOME, ZA, ZC, USE and CONSERV were as defined for Model 1.

In this specification, $b_{1}$ is expected to be positive because higher income generally leads to higher spending on all goods with positive utility, including installation of ECMs. The signs of $b_{2}, b_{3}$, and $b_{4}$ are dependent on whether "installing solar" was the most expensive ECM among the four categories of ECMs noted. If it was, then $b_{2}, b_{3}$, and $b_{4}$ would be negative. Otherwise, coefficients $b_{2}, b_{3}$, and $b_{4}$ could also be positive or zero. Coefficient $c$ is expected to be positive, assuming that Hypothesis No. 2 is true. As in Model 1 , coefficients $d_{1}$ and $d_{2}$ are expected to be positive.

Variations of the above specification can be derived by substituting the alternative $Z C$ variable for $Z A$, by dropping variables such as USE and CONSERV, or by combination of the above.

\subsubsection{Data}

To better understand the data underlying the definition of FINVEST, Ques tions 234, 235, and 236 need to be reviewed:

Question 234: "There are many ways to reduce your energy use at home. Some of these ways involve spending money on such things as solar water heating, insulation, and heat pumps. Other ways require changes in the way you 1 ive, such as lowering the thermostat, using less hot water, wearing a sweater 
indoors in the winter, and so forth. Given a choice between the two--spending money on improvements or changing the way you live--which would you say you would rather do to save energy at home?"

Question 235: "What would be the FIRST measure you would adopt?"

FINVEST was then defined from the responses to Question 236: "What is the most you would be willing to spend on this action?"

The dummy variables for the type of ECMS, TECM1, TECM2, and TECM3 were defined in terms of the responses to Question 235. It was clear from the above that the responses to Question 235 contained measures and actions that were in the "changing ways of living" category, rather than in the "spending money on improvements" category. Our interest in this analysis was mainly in the.

"spending for improvements" category. Review of the frequency distribution for Question 235 indicated that four types of ECMs were mentioned by the respondents for the first measure: "install solar", wood stove, "insulate or weatherize", and "all others". The three dummy variables completely define the four types of measures for regression analysis purposes. TECM1 is the dummy variable for wood stove; TECM2 for "insulate or weatherize"; TECM3 for "all other" except "install solar" which is the reference point for the TECMs. Thus the representation of the type of ECM can be shown as follows:

\begin{tabular}{|c|c|c|c|}
\hline & TECM1 & TECM2 & TECM3 \\
\hline Install solar & 0 & 0 & 0 \\
\hline Wood Stove & 1 & 0 & 0 \\
\hline Insulate/Weatherize & 0 & 1 & 0 \\
\hline "All Other" & 0 & 0 & 1 \\
\hline
\end{tabular}

Note that the "all other" category included limited mentions of "changing fuel sources", "get a clock or setback thermostat", and "install fireplace insert". 


\subsubsection{Regression Results}

Table 5.3 presents the unweighted regression results for Model 2, the maximum amount that individual respondents are willing to spend for the first measures (FINVEST) they are likely to install in the future. The following discussion interprets the results.

The individual regression equations are statistically significant according to the F-test, but only about 20 percent of variations of the FINVEST variable are explained by the variables included in the equations. Overall, the most influential variables in the regression appear to be the dummy variable representing the installation of wood stove (TECM1), that representing insulation and weatherization (TECM2), and the intercept term. In a sense, the intercept term representing the average cost of "installing solar" after accounting for income and the dummy variables for the view that installation of ECMs are home improvement, and so on. None of the coefficients for the other variables have significant estimates.

Estimates for the intercept term are significant in 6 of the 8 equations at either the $5 \%$ or $1 \%$ significance level. The other two are not quite significant at the 5\% level. Coefficients for TECM1 and TECM2 are negative and significant. They are negative because the amount of money that the respondents would spend installing a wood stove (TECM1) or adding insulation and weatherizing their house (TECM2) would likely be less than the amount they would have to spend on the category "install solar". The range of estimates for TECM1 is between about $-\$ 3000$ and $-\$ 3300$. Similarly, the range for TECM2 is between about $-\$ 2700$ to about $-\$ 2900$. The coefficient for the category "a 11 other measures" is not significant, probably because this was a mixed category, covering things such as installing clock or setback thermostat, and conversion to other fuels.

The household income variable (INCOME) has the expected sign, but is not significant. This may indicate that, given the one measure that the respondent has mentioned, the amount given (FINVEST) was an indication of the respondent's estimation of the cost of the measures. Higher income individuals may estimate the costs to be somewhat but not significantly higher. 
TABLE 5.3. Unweighted Regression Results for the Amount Potentially Spent on the First Energy Conservation Measure to be Installed in the Future

Model 2. Dependent Varlable: FINVENST

\begin{tabular}{|c|c|c|c|c|c|c|c|c|}
\hline & & & & Homeowners & Only $(n=112)$ & & & \\
\hline Equation & (1) & $(2)$ & (3) & (4) & (5) & (6) & $(7)$ & (8) \\
\hline Intercept & $\begin{array}{l}3199.4^{* *} \\
(3.270)\end{array}$ & $\begin{array}{l}3458.8^{* *} \\
(3.680)\end{array}$ & $\begin{array}{r}3708.9 * * \\
(2.978)\end{array}$ & $\begin{array}{l}2761.3 \\
\quad(1.523)\end{array}$ & $\begin{array}{l}3034.1 \\
\quad(1.64)\end{array}$ & $\begin{array}{l}3905.9^{* *} \\
(3.193)\end{array}$ & $\begin{array}{c}3307.3^{*} \\
(1.962)\end{array}$ & $\begin{array}{l}3578.8^{*} \\
(2.049)\end{array}$ \\
\hline INCOME & $\begin{array}{r}0.0326 \\
(1.577)\end{array}$ & $\begin{array}{r}0.0305 \\
(1.498)\end{array}$ & $\begin{array}{r}0.0308 \\
(1.474)\end{array}$ & $\begin{array}{r}0.0336 \\
(1.596)\end{array}$ & $\begin{array}{r}0.0321 \\
(1.518)\end{array}$ & $\begin{array}{r}0.0289 \\
(1.397)\end{array}$ & $\begin{array}{r}.0308 \\
(1.495)\end{array}$ & $\begin{array}{r}.0292 \\
(1.406)\end{array}$ \\
\hline TECM1 & $\begin{array}{r}-3210.8^{* *} \\
(-2.954)\end{array}$ & $\begin{array}{r}-3296.4^{* *} \\
(-3.020)\end{array}$ & $\begin{array}{r}-3185.4^{* *} \\
(-2.921)\end{array}$ & $\begin{array}{r}-3157.4^{* *} \\
(-2.852)\end{array}$ & $\begin{array}{r}-3083.9^{* *} \\
(-2.770)\end{array}$ & $\begin{array}{r}-3270.8^{* *} \\
(-2.895)\end{array}$ & $\begin{array}{r}-3277.3^{* *} \\
(-2.950)\end{array}$ & $\begin{array}{r}-3219.4^{* *} \\
(-2.88)\end{array}$ \\
\hline TECM2 & $\begin{array}{r}-2840.7 * * \\
(-3.679)\end{array}$ & $\begin{array}{r}-2899.1 * * \\
(-3.724)\end{array}$ & $\begin{array}{r}-2791.1^{* *} \\
(-3.588)\end{array}$ & $\begin{array}{r}-2798.7^{* *} \\
(-3.546)\end{array}$ & $\begin{array}{r}-2704.6^{* *} \\
(-3.381)\end{array}$ & $\begin{array}{r}-2851.2^{* *} \\
(-3.631)\end{array}$ & $\begin{array}{r}-2883.0^{* *} \\
(-3.622)\end{array}$ & $\begin{array}{r}-2804.7^{* *} \\
(-3.470)\end{array}$ \\
\hline TECM3 & $\begin{array}{l}2480.7 \\
\quad(1.321)\end{array}$ & $\begin{array}{l}2518.8 \\
\quad(1.346)\end{array}$ & $\begin{array}{l}2591.5 \\
(1.371)\end{array}$ & $\begin{array}{r}2476.5 \\
(1.313)\end{array}$ & $\begin{array}{l}2608.3 \\
\quad(1.375)\end{array}$ & $\begin{array}{l}2624.7 \\
\quad(1.391)\end{array}$ & $\begin{array}{l}2522.1 \\
(1.341)\end{array}$ & $\begin{array}{l}2646.1 \\
\quad(1.395)\end{array}$ \\
\hline ZA & $\begin{array}{l}507.8 \\
(0.659)\end{array}$ & & $\begin{array}{l}540.9 \\
(0.698)\end{array}$ & $\begin{array}{l}567.7 \\
(0.708)\end{array}$ & $\begin{array}{l}655.9 \\
(0.808)\end{array}$ & & & \\
\hline $\mathrm{ZC}$ & & $\begin{array}{r}-2604.0 \\
(-0.735)\end{array}$ & & & & $\begin{array}{r}-2469.9 \\
(-0.693)\end{array}$ & $\begin{array}{r}-2604.6 \\
(-0.732)\end{array}$ & $\begin{array}{r}-2455.1 \\
(-0.686)\end{array}$ \\
\hline USE & & & $\begin{array}{l}-599.5 \\
(-0.684)\end{array}$ & & $\begin{array}{r}-731.8 \\
(-0.775)\end{array}$ & $\begin{array}{r}-517.9 \\
(-0.514)\end{array}$ & & $\begin{array}{l}-581.3 \\
(-0.620)\end{array}$ \\
\hline CONSERV & & & & $\begin{array}{l}393.0 \\
(0.288)\end{array}$ & $\begin{array}{l}706.2 \\
(0.495)\end{array}$ & & $\begin{array}{l}143.2 \\
(0.109)\end{array}$ & $\begin{array}{l}360.9 \\
(0.264)\end{array}$ \\
\hline$R^{2}$ & 0.1998 & .2006 & 0.2031 & 0.2004 & 0.2050 & .2030 & .2006 & .2036 \\
\hline$R^{2}(\operatorname{Ad} \mathbf{j})$ & 0.1620 & .1628 & 0.1576 & 0.1547 & 0.1515 & .1575 & .1550 & 0.1500 \\
\hline$F$ & 5.292 & 5.318 & 4.460 & 4.385 & 3.830 & 4.459 & 4.393 & 3.798 \\
\hline Prob. $>F$ & 0.0003 & 0.0002 & 0.0005 & 0.0005 & 0.0010 & 0.0005 & 0.0005 & 0.0011 \\
\hline
\end{tabular}

Numbers in parentheses are t-values.

* Signiflcant at the $5 \%$ level. 
$Z A$ is not significant probably for the same reason as explained above. ZC has the wrong sign but is not significant.

\subsection{DATA ON AVERAGE CONSERVATION INVESTMENTS}

To supplement the above analyses, this section presents data on average conservation investments during 1983-85 at different levels of disaggregation, using two different proxies for the view on installation of ECMs as home improvement. The number and the type of ECMs are used for disaggregation. One control variable is the agreement or disagreement with the statement that "I would only make conservation improvements that would increase the value of my home." (This is variable ZA in the regression analyses.) A second control variable is whether a respondent expected "more comfort" as a result of installing any ECM.

Table 5.4 presents the average investments of those who agreed or disagreed with the statement that "I would only make conservation improvements which would enhance the value of my home," by the number of ECMs. On the average, the average investment of the two groups were about equal. However,

TABLE 5.4. Average Conservation Investments (weighted) Made During 1983-85 by Number of ECMs Installed and Agreement with the Statement "I would only make conservation improvements which would enhance the value of my home."

\begin{tabular}{|c|c|c|c|c|c|c|}
\hline \multirow{2}{*}{$\begin{array}{l}\text { Number } \\
\text { of ECMs } \\
\text { Installed }\end{array}$} & \multicolumn{2}{|c|}{ All Homeowners } & \multicolumn{2}{|c|}{$\begin{array}{l}\text { Homeowners } \\
\text { Who Agree }\end{array}$} & \multicolumn{2}{|c|}{$\begin{array}{l}\text { Homeowners } \\
\text { Who Disagree }\end{array}$} \\
\hline & $n$ & $\begin{array}{c}\text { Average } \\
\text { Inves tment }\end{array}$ & $\underline{n}$ & $\begin{array}{c}\text { Average } \\
\text { Investment }\end{array}$ & $n$ & $\begin{array}{c}\text { Average } \\
\text { Investment }\end{array}$ \\
\hline 1 & 93 & $\$ 1,345$ & 22 & $\$ 1,242$ & 71 & $\$ 1,376$ \\
\hline 2 & 54 & 1,424 & 10 & 1,144 & 44 & 1,484 \\
\hline 3 & 28 & 3,037 & 6 & 1,307 & 22 & 3,544 \\
\hline 4 & 12 & 5,002 & 2 & 16,288 & 10 & 1,838 \\
\hline 5 & 11 & 2,251 & 2 & 736 & 9 & 2,603 \\
\hline 6 & 2 & 2,750 & 0 & - & 2 & 2,750 \\
\hline 7 & 4 & 5,840 & 1 & 300 & 3 & 10,153 \\
\hline Total & 300 & $\$ 1,574$ & 61 & $\$ 1,595$ & 239 & $\$ 1,569$ \\
\hline
\end{tabular}


except for cases with the number of ECMs equal to 1,4 or 6 , those who agreed with the statement tended to have smaller average investments. For example, for those homeowners who have had installed two ECMs, the average investment of those who agreed with the statement was about $\$ 1,144$, compared with about $\$ 1,484$ for those who disagreed. For homes with three ECMs installed during 1983-85, the average investment was about $\$ 1,307$ for those who agreed with the statement, compared with $\$ 3,544$ for those who disagreed with the statement. In contrast, for the number of ECMS equal to four, those who agreed with the statement averaged over $\$ 16,000$, while those who disagreed had an average investment of $\$ 1,838$. This group illustrates the impacts of extreme values on average investment, especially when the sample size is small.

Since ECMs differ in costs, it is useful to further control for the type of ECMs installed. Table 5.5 presents the average investments for homeowners who have installed only one ECM during the period under consideration, controlling for the specific type of ECM installed. At this level of disaggregation, the number of observations for specific categories becomes quite small

TABLE 5.5. Average Conservation Investments (weighted) of Homeowners Who Have Installed only One ECM During 1983-85 by ECM and Agreement with the Statement "I would only make conservation improvement which would enhance the value of my home."

\begin{tabular}{|c|c|c|c|c|c|c|}
\hline \multirow[b]{2}{*}{ ECM } & \multirow{2}{*}{ Al1 } & \multirow{2}{*}{$\frac{\text { Homeowners }}{\text { Investment }}$} & \multicolumn{2}{|c|}{$\begin{array}{c}\text { Homeowners } \\
\text { Who Agree }\end{array}$} & \multicolumn{2}{|c|}{$\begin{array}{l}\text { Homeowners } \\
\text { Who Disagree }\end{array}$} \\
\hline & & & $n$ & Investment & $n$ & Investment \\
\hline Weatherproofing & 46 & $\$ 1388$ & 10 & $\$ 702$ & 36 & $\$ 1552$ \\
\hline Wood Stove & 11 & 701 & 4 & 473 & 7 & 824 \\
\hline Roof Insulation & 10 & 1336 & 1 & 50 & 9 & 1443 \\
\hline Storm Doors & 7 & 1949 & 1 & 5000 & 6 & 1327 \\
\hline Fireplace Insert & 6 & 1277 & 0 & -- & 6 & 1277 \\
\hline Storm Windows & 5 & 1380 & 2 & 915 & 3 & 1736 \\
\hline Automatic Thermostat & 4 & 591 & 1 & 600 & 3 & 589 \\
\hline Floor Insulation & 3 & 2515 & 2 & 3050 & 1 & 200 \\
\hline Wall Insulation & 1 & 2500 & 0 & -- & 1 & 2500 \\
\hline Total & 93 & $\$ 1345$ & 22 & $\$ 1241$ & 71 & $\$ 1376$ \\
\hline
\end{tabular}


and the average investment estimates can be greatly affected by extreme values. The number of respondents who agree with the statement in question are less than 4 except for weatherproofing and wood stoves. For these two ECMS, the average investments for those who agreed with the statement are lower than for those who disagreed with the statement.

Table 5.6 presents similar kind of data as presented in Table 5.5, but controlling for a combination of two ECMs. The table indicates that for homeowners who installed weatherproofing and storm doors, there is only minor difference between those who agreed and who disagreed with the statement. However, overall, those who agreed with the statement spent less than those who disagreed by about $\$ 300$.

Table 5.7, 5.8, 5.9 present similar data as Tables, 5.4 through 5.6, except that the control variable is whether "more comfort" is mentioned by the respondent following installation of specific ECMs. Overall, those who indicated "more comfort" appeared to have spent more than those who did not mention it. For the number of ECMs equal 3, the average investment of those who expected more comfort are larger than those who did not mention more comfort. For the number of ECMs equals to 4 and 7 , the average investments of

TABLE 5.6. Average Conservation Investments (weighted) of Homeowners Who Have Installed Two ECMs During 1983-85 by Combination of ECMs and Agreement with the Statement "I would only make conservation improvements which would enhance the value of my home."

\begin{tabular}{|c|c|c|c|c|c|c|}
\hline \multirow[b]{2}{*}{ Combination of ECMs } & \multicolumn{2}{|c|}{ All Homeowners } & \multicolumn{2}{|c|}{$\begin{array}{l}\text { Homeowners } \\
\text { Who Agree }\end{array}$} & \multicolumn{2}{|c|}{$\begin{array}{l}\text { Homeowners } \\
\text { Who Disagree }\end{array}$} \\
\hline & n & $\begin{array}{c}\text { Average } \\
\text { Investment }\end{array}$ & $n$ & $\begin{array}{c}\text { Average } \\
\text { Investment }\end{array}$ & $n$ & $\begin{array}{c}\text { Average } \\
\text { Investment }\end{array}$ \\
\hline Weatherproofing, Storm Doors & 11 & $\$ 1854$ & 1 & $\$ 2000$ & 10 & $\$ 1845$ \\
\hline Weatherproofing, Storm Windows & 7 & 748 & 3 & 737 & 4 & 753 \\
\hline Weatherproofing, Wood Stove & 5 & 817 & 1 & 900 & 4 & 1017 \\
\hline Weatherproofing, Roof Insulation & 4 & 743 & 0 & - & 4 & 743 \\
\hline Storm Whndows, Sotrm Doors & 4 & 2159 & 0 & - & 4 & 2159 \\
\hline Weatherproofing, Floor Insulation & 3 & 495 & 1 & 800 & 2 & 425 \\
\hline Storm Windows, Floor Insulation & 1 & 3000 & 0 & -- & 1 & 3000 \\
\hline Storm Windows, Woodstove & 1 & 4000 & 0 & -- & 1 & 4000 \\
\hline All other comblnations of 2 ECMs & 18 & 1576 & 4 & 1705 & 14 & 1533 \\
\hline Total & 54 & $\$ 1424$ & 10 & $\$ 1143$ & 44 & $\$ 1484$ \\
\hline
\end{tabular}


TABLE 5.7. Average Conservation Investments (weighted) Made During 1983-85 by Number of ECMs Installed and the Expectation of "More Comfort" Following Installation of the ECMs

\begin{tabular}{|c|c|c|c|c|c|c|}
\hline \multirow{2}{*}{$\begin{array}{c}\text { Number } \\
\text { of ECMs } \\
\text { Installed } \\
\end{array}$} & \multicolumn{2}{|c|}{ Al1 Homeowners } & \multicolumn{2}{|c|}{$\begin{array}{l}\text { Homeowners } \\
\text { Who Expected } \\
\text { "More Comfort" }\end{array}$} & \multicolumn{2}{|c|}{$\begin{array}{l}\text { Homeowners Who } \\
\text { Did Not Mention }\end{array}$} \\
\hline & $n$ & $\begin{array}{c}\text { Average } \\
\text { Investment }\end{array}$ & $n$ & $\begin{array}{c}\text { Average } \\
\text { Investment }\end{array}$ & $n$ & $\begin{array}{c}\text { Average } \\
\text { Inves tment }\end{array}$ \\
\hline 1 & 93 & $\$ 1345$ & 27 & $\$ 1439$ & 66 & $\$ 1306$ \\
\hline 2 & 54 & 1424 & 12 & 1458 & 42 & 1412 \\
\hline 3 & 28 & 3037 & 13 & 3839 & 15 & 2219 \\
\hline 4 & 12 & 5002 & 7 & 1347 & 5 & 9617 \\
\hline 5 & 11 & 2251 & 4 & 2068 & 7 & 2415 \\
\hline 6 & 2 & 2750 & 1 & 3000 & 1 & 2500 \\
\hline 7 & 4 & 5840 & 1 & 3000 & 3 & 6561 \\
\hline Total & 300 & $\$ 1574$ & 81 & $\$ 1774$ & 219 & $\$ 1497$ \\
\hline
\end{tabular}

TABLE 5.8. Average Conservation Investments (weighted) of Homeowners Who Have Installed Only One ECM During 1983-85 by ECM and the Expectation of More Comfort Following Installations

\begin{tabular}{|c|c|c|c|c|c|c|}
\hline \multirow[b]{2}{*}{$\mathrm{ECM}$} & \multicolumn{2}{|c|}{ A11 Homeowners } & \multicolumn{2}{|c|}{$\begin{array}{l}\text { Homeowners } \\
\text { Who Mentioned } \\
\text { "More Comfort" }\end{array}$} & \multicolumn{2}{|c|}{$\begin{array}{l}\text { Homeowners Who } \\
\text { Did Not Mention } \\
\text { "More Comfort" }\end{array}$} \\
\hline & $n$ & Investment & $n$ & Investment & $n$ & Investment \\
\hline Weatherproofing & 46 & $\$ 1388$ & 18 & $\$ 1786$ & 28 & $\$ 1163$ \\
\hline Wood Stove & 11 & 701 & 1 & 350 & 10 & 764 \\
\hline Roof Insulation & 10 & 1336 & 1 & 500 & 9 & 1405 \\
\hline Storm Doors & 7 & 1949 & 1 & 500 & 6 & 2170 \\
\hline Fireplace Insert & 6 & 1277 & 2 & 1053 & 4 & 1398 \\
\hline Storm Windows & 5 & 1380 & 1 & 2500 & 4 & 1053 \\
\hline Automatic Thermostat & 4 & 591 & 1 & 1500 & 3 & 361 \\
\hline Floor Insulation & 3 & 2515 & 2 & 132 & 1 & 6000 \\
\hline Wall Insulation & 1 & 2500 & 0 & -- & 1 & 2500 \\
\hline Total & 93 & $\$ 1345$ & 27 & $\$ 1439$ & 66 & $\$ 1305$ \\
\hline
\end{tabular}


TABLE 5.9. Average Conservation Investments (weighted) of Homeowners Who Have Installed Two ECMs During 1983-85 by Combination of ECMs and the Expectation of "More Comfort" Following Installation

\begin{tabular}{|c|c|c|c|c|c|c|}
\hline \multirow[b]{2}{*}{ Combination of ECMs } & & \multicolumn{2}{|c|}{$\begin{array}{l}\text { Homeowners } \\
\text { Who Mentioned } \\
\text { "More Comfort" }\end{array}$} & \multicolumn{2}{|c|}{$\begin{array}{l}\text { Homeowners Who } \\
\text { Did Not Mention } \\
\text { "More Comfort" }\end{array}$} \\
\hline & $\pi$ & Investment & $n$ & Investment & $n$ & Investment \\
\hline Weatherproofing, Storm Doors & 11 & $\$ 1854$ & 2 & $\$ 1100$ & 9 & $\$ 1947$ \\
\hline Weatherproofing, Storm Windows & 7 & 748 & 1 & 2000 & 6 & 508 \\
\hline Weatherproofing, Wood Stove & 5 & 817 & 1 & 1000 & 4 & 729 \\
\hline Weatherproofing, Roof Insulation & 4 & 743 & 0 & - & 4 & 743 \\
\hline Storm Window, Storm Doors & 4 & 2159 & 1 & 1500 & 3 & 2372 \\
\hline Weatherproofing, Floor Insulation & 3 & 495 & 1 & 600 & 2 & 424 \\
\hline Storm Windows, Floor Insulation & 1 & 3000 & 1 & 3000 & 0 & - \\
\hline Storm Windows, Wood Stove & 1 & 4000 & 0 & - & 1 & 4000 \\
\hline All other combinations of 2 ECMs & 18 & 1576 & 5 & 1334 & 13 & 1694 \\
\hline Total & 54 & $\$ 1424$ & 12 & $\$ 1457$ & 42 & $\$ 1412$ \\
\hline
\end{tabular}

those who expected more comfort are less than those who did not mention it. For the other cases (NECM $=1,2$ and 5) the average investments are about equal (Table 5.7).

For respondents who only weatherproofed their homes during the 1983-85, the average investment of those who mentioned more comfort are somewhat higher than who did not mention it. For other categories of ECMs, the number of households in each of the other category who expected more comfort from installation of ECMs were relatively small (less than 3 ). Hence the average investment can be greatly affected by extreme values. It appears that none of the individual combinations had a large enough sample size (Table 5.8). Similar comments apply to the data presented in Table 5.9.

The following observations can be made. First, the disaggregated data on average conservation investments do not yield consistent results to allow for generalization. Second, it appears that the nature of the data on the amount of past conservation investment leaves much to be desired. Since these data are reported by respondents over the telephone without referring back to their records, they may not be very precise. As spending on installation of energy conservation measures is not a recurring expense, consumers are unlikely to 
remember it precisely unless they make a special effort to do so. Hence, the specific values given consumers are likely to be only approximations to the true values. Moreover, in answering the question on the amount of money spent on energy conservation investment, some respondents may give the total amount spent including expenses for other types of home improvements, such as remodeling costs. Therefore, the average investment data should be regarded only as approximate order of magnitudes. To use the data for hypothesis testing and other inferences, substantial work in cleaning up the data would be required.

\subsection{DISCUSSION}

The hypothesis tested in this chapter is that, other things being equal, those who view installation of energy conservation measures as home improvement will be willing to spend more than other groups of consumers on conservation (Hypothesis No. 2). This hypothesis cannot be confirmed by regression analysis using the data on conservation investments made during 1983-85 and potential future investments. When individuals who specifically mentioned that the expected benefits of installing specific ECMs was "increased value of the home" were used to represent the group of consumers who would view installation of ECMS as home improvement and the regression was unweighted, some significant result was derived. In this instance, it was estimated that those with the home improvement view have spent approximately between $\$ 1900$ and $\$ 2000$ more than those who did not hold such view. However, this result was based on relatively small number of observations. When the home improvement view was represented by agreement with the statement that "I would only make conservation improvements which would enhance the value of my home", the hypothesis cannot be confirmed with data on past investment. Similarly, regression analyses using data on the maximum amount of money respondents would be willing to spend on the first ECM to be installed in the future could not confirm Hypothesis No. 2 at all.

From the perspective of energy conservation planning, the above analysis results do not give definitive support to segmenting the market by the view of installations of ECMs as home improvement. Although it is still possible that holding the home improvement view may raise the amount of spending on energy 
conservation, but the two ways of measuring the perception that installation of ECMs is home improvement used in the above analysis are not satisfactory. A better measure would be to use the responses to a more direct question such as this: "Would you personally regard installing energy conservation measures in your house as a home improvement?" If the same hypothesis is to be tested again in future surveys, it would be necessary to include such a question in the survey instrument.

Furthermore, disaggregation of average conservation investments by the number and the type of energy conservation measures do not yield consistent results to allow for generalizations. Data on the amount of investment data collected in telephone surveys would need to be closely scrutinized to reduce the impacts of extreme value or outliers. 


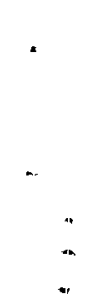




\subsection{EXPLORATIONS ON DETERMINING THE THRESHOLD LEVEL OF CONSERVATION INVESTMENT FOR FINANCING WITH LOANS}

One hypothesis under consideration in this report states that there is a threshold level of spending on conservation above which consumers use loans and/or long-term financing rather than cash or current income (Hypothesis $3 A$ ). The hypothesis further states that, if a threshold exists, it will vary by demographics (Hypothesis 3B). It also specifies that the threshold should be calculated as a percent of income to control for varying income levels. This chapter presents exploratory analyses conducted to test these two related hypotheses. The approach used in the analysis, including 2 by 2 contingency table analysis and the logit model, are explained first. Applications of the contingency table analysis to the total sample without controlling for individual demographic and other factors and to individual cases when controlling for specific demographic and other variables are detailed in sequence. Estimation of the logit model and interpretation of the results are then discussed. Finally, analysis results are summarized and their implications noted.

Note that the analysis in this chapter was based on the data on financing the investments made during the 1983-85 period. Note also that households with zero investment were excluded from the analysis because the question of financing is irrelevant when no investment was made.

\subsection{APPROACH}

If the first part of the hypothesis under consideration (Hypothesis $3 \mathrm{~A}$ ) were true, then one of the results that could be observed would be that, above the threshold level of conservation investment, the proportion of respondents who financed with loans would be significantly higher than the same proportion for those who funded their investments through current income, savings and other sources. To identify the threshold, it would be possible to assign different potential threshold levels and employ the 2 by 2 contingency table analysis to test the null hypothesis that financing sources are not related to the ratio of conservation investment to household income. When the potential threshold level is very low, either the chi-squares test could not be conducted 
because of the requirement that less than $20 \%$ of the cells of the contingency table have frequency of 5 or less is not met, or the test would be insignificant. As the potential threshold level is raised, two possible outcomes of the contingency table analysis would occur. First, the chi-square test will become significant at some point if the attentive hypothesis is true. Second, the test would remain not significant throughout if the null hypothesis is true. Therefore, it is reasonable to adopt the decision rule that the threshold level can be set at the lowest level of the investment to income ratio where the chisquares test first becomes significant for a particular distribution.

To apply the approach described above, the following steps are required:

1. Compute the values of the ratio of conservation investment to household income, termed GI in the following analysis.

2. Construct frequency distributions for GI for the entire sample (excluding renters), for those who financed their conservation investment through loans, and for those who financed with other sources such as current income and savings. For example, the different classes of GI can be tentatively set as follows:

\begin{tabular}{|c|c|}
\hline $\mathrm{Class}$ & $s$ of \\
\hline under & 0.001 \\
\hline 0.0011 & -0.005 \\
\hline 0.0051 & -0.01 \\
\hline 0.011 & -0.02 \\
\hline 0.021 & -0.03 \\
\hline 0.031 & -0.04 \\
\hline 0.041 & -0.05 \\
\hline 0.051 & -0.06 \\
\hline 0.061 & -0.10 \\
\hline 0.11 & -0.20 \\
\hline 0.21 & d o \\
\hline
\end{tabular}


The class specifications can be modified in accordance with the actual range of computed GI values.

3. Compare the distribution of the GI with loan financing with that financed through cash or current income. If the first few classes in the distribution with loan financing were filled with zeros while the corresponding classes of the other distribution with cash or current income financing were not, then this is suggestive of the existence of the threshold level of GI. For example, assume the following distributions were derived for the total effective sample:

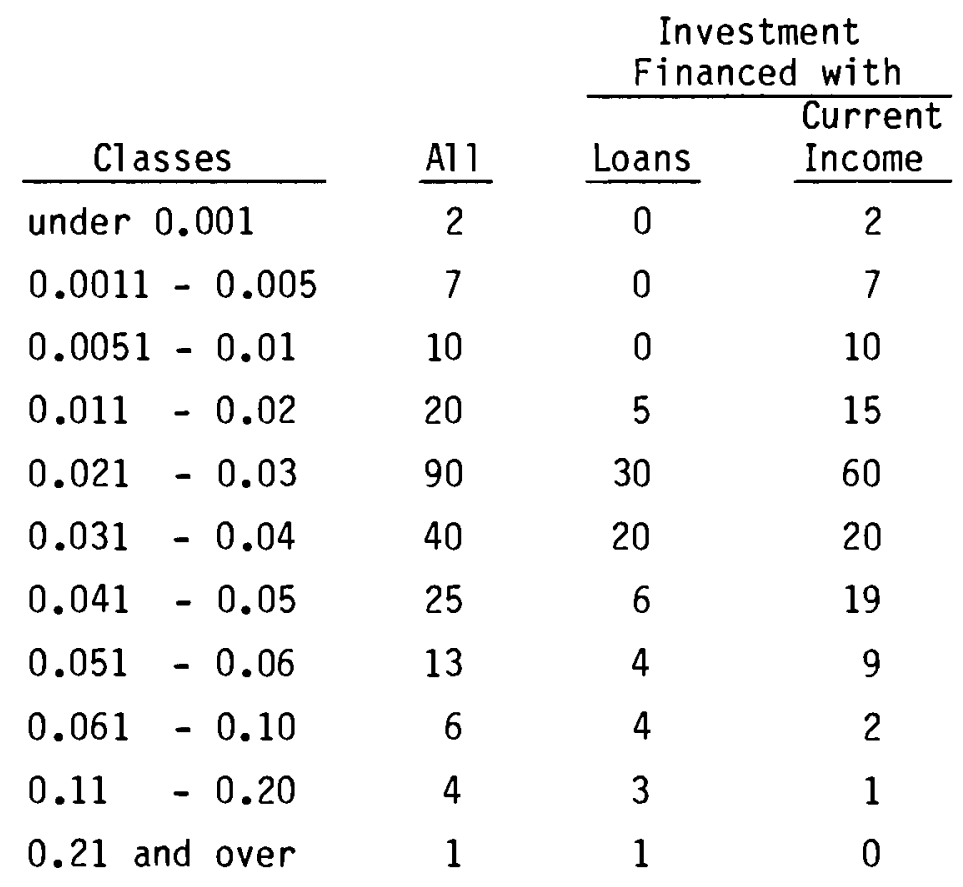

In the above example, the threshold level can be initially set at between 0.01 to 0.02 .

4. Conduct 2 by 2 contingency table analyses using chi-square tests by assigning different threshold levels for GI above 0.01 (1\%). If this assumed threshold level (1\%) were not true threshold level, then the test would not be significant. The lowest level of GI at which the test becomes significant, will be regarded as the threshold level for this particular case. 
5. Repeat Steps 2, 3 and 4 controlling for demographic variables such as income, education, age, sex, occupation and other demographic variables to determine if there is a relationship between the threshold levels and demographics.

In addition to the contingency table analysis described above, the logit model is also employed to estimate the probability function of a household financing with loans. By definition, a household either financed its conservation investment with loans or paid for the investment with current income, savings or other sources. Define $P$ (Finance) as the probability of financing with loans or paid for with other sources. For individual respondents, the actual observations show that $P($ Finance $=$ Loans $)=1$ and $P($ Finance $=$ Other Sources $)=0$. The hypothesis under consideration implies that the probability of a household financing with loans is positively related to the investment to income ratio (GI) and that beyond a certain threshold level that relationship would be at a much higher level than below the threshold level.

Using the logit model, the probability of a household financing its conservation investment with loans can be approximated by the following function:

$$
P(\text { Loans })=\frac{\operatorname{EXP}(a+b \star G I)}{1+\operatorname{EXP}(a+b \star G I)}
$$

where $\operatorname{EXP}($ ) is the exponential function; GI the investment to income ratio; and $a$ and $b$ the coefficients to be estimated through logistic regression. Given the threshold level identified above through the 2 by 2 contingency table analysis, the sample can be divided into two subparts, and separate estimates of parameters $a$ and $b$ can be estimated. If the two sets of parameters $\left(a_{1}, b_{1}\right.$ and $a_{2}, b_{2}$ ) turn out to be substantially different from each other, then it may be appropriate to represent the outcome by a combined probability distribution. An example, assuming the threshold level is at the $2 \%$ level, is shown below: 


$$
P(\text { Loans })= \begin{cases}\frac{\operatorname{EXP}\left(a_{1}+b_{1} * G I\right)}{1+\operatorname{EXP}\left(a_{1}+b_{1} * G I\right)} & \text { if } G I \leqslant 0.02 ; \text { or } \\ \frac{\operatorname{EXP}\left(a_{2}+b_{2} * G I\right)}{1+\operatorname{EXP}\left(a_{2}+b_{2} * G I\right)} & \text { if } G I>0.02 .\end{cases}
$$

\subsection{ANALYSIS OF TOTAL SAMPLE AS A WHOLE}

Table 6.1 presents the frequency distribution by the value of the investment to household income ratio, GI, based on conservation investments made

TABLE 6.1. Distribution of Homeowners by the Ratio of 1983-85 Conservation Investment to Household Income

\begin{tabular}{|c|c|c|}
\hline $\begin{array}{l}\text { Conservation Investment } \\
\text { as \% of Household Income } \\
\end{array}$ & $\begin{array}{l}\text { Number of } \\
\text { Homeowners }(a) \\
\text { (in 1000s) }\end{array}$ & $\begin{array}{c}\text { Proportional } \\
\text { Share } \\
\end{array}$ \\
\hline under $\quad 0.1 \%(b)$ & 27 & $3 \%$ \\
\hline $0.1-0.5$ & 93 & 10 \\
\hline $0.5-1.0$ & 114 & 13 \\
\hline $1.0-2.0$ & 141 & 16 \\
\hline $2.0-3.0$ & 75 & 8 \\
\hline $3.0-4.0$ & 83 & 9 \\
\hline $4.0-5.0$ & 31 & 3 \\
\hline $5.0-6.0$ & 30 & 3 \\
\hline $6.0-10.0$ & 145 & 16 \\
\hline $10.0-20.0$ & 101 & 11 \\
\hline over $\quad 20.0$ & 67 & 7 \\
\hline Total & 909 & $100 \%$ \\
\hline
\end{tabular}

(a) Data have been weighted to represent population values.

(b) $0.0 \%$ is excluded. The upper limit of each class is inclusive. 
during 1983-85. (a) Table 6.2 presents the frequency distributions of those who financed with loans and those who financed with all other sources, by the ratios of the investment to income ratio. Except for the first class of those less than $0.1 \%$, the proportions of those who financed with loans in the GI classes between $0.1 \%$ and $4.0 \%$ were less than the corresponding proportions of those who paid for the investment with sources other than loans. In the class of 4 to $5 \%$, the proportion of those who financed with loans exceeded that

TABLE 6.2. Distribution of Homeowners by the Ratio of 1983-85 Conservation Investment to Household Income by Type of Financing

Conservation Investment as \% of Household Income

$$
\begin{gathered}
\text { under } \quad 0.1 \%(a) \\
0.1-0.5 \\
0.5-1.0 \\
1.0-2.0 \\
2.0-3.0 \\
3.0-4.0 \\
4.0-5.0 \\
5.0-6.0 \\
6.0-10.0 \\
10.0-20.0 \\
\text { over } 20.0
\end{gathered}
$$

Number of Homeowners (in 1000s)

Type of Financing $(n=881)$

Loans
$(n=86)$
$(n=795)$

$\begin{array}{rr}6 \% & 3 \% \\ 0 & 12 \\ 9 & 13 \\ 4 & 17 \\ 4 & 9 \\ 5 & 10 \\ 5 & 3 \\ 2 & 4 \\ 22 & 14 \\ 22 & 10 \\ 21 & 5\end{array}$

(a) $0.0 \%$ is excluded. The upper limit of each class is inclusive.

(a) Note that GI, the investment to household income ratio, is computed by dividing the amount of investment over the two-year period of 1983-1985 with the annual household income. As a result, the real burden to the consumer is only about half of the resulting values indicated. For convenience, the analysis can be treated as covering a two-year period. This qualification applies throughout this chapter. 
of those who financed with other sources. In the class of 5 to $6 \%$ for the investment to income ratio, the proportion of those financing with loans was somewhat lower than that of those paying with other sources. Beyond $6 \%$, the shares of those who financed with loans became consistently above that of those who financed with other sources.

The above observation suggested an alternative decision rule for determining the threshold level of conservation investment above which consumers are more likely to finance with loans; i.e., the threshold level is the investment to income ratio at which the proportions of those who financed their investments with loans are consistently higher than the proportions of those who financed with other sources. In the case of the overall sample as presented in Table 6.2, this particular decision rule would give us the threshold level at either $4 \%$ or $6 \%$. However, since the limits of the classes are determined somewhat arbitrarily, different assignments of class limits may affect the threshold levels determined with this decision rule. In contrast, the threshold level determined with first significant chi-square test approach was relatively unique. Hence, the decision rule that the threshold level is at the lowest possible level of conservation investment to household income ratio where the chi-square test first became significant was adopted.

Table 6.3 presents the summary results of different 2 by 2 contingency table analyses conducted with the data shown in Table 6.2. The following illustrates how the results should be interpreted:

- If the threshold level was set at the $1 \%$ of household income, then the proportion of respondents who financed with loans above the threshold level was $81 \%$. This can be compared to the $72 \%$ for those who did not finance with loans. The chi-square test was not significant, meaning that the null hypothesis that there was no relationship between the ratio of investment to household income and the financing source of past conservation investment cannot be rejected. In other words, the $81 \%$ was not significantly larger than than the $72 \%$. This implies that the $1 \%$ level was not the true threshold level. 
TABLE 6.3. Summary Results of 2 by 2 Contingency Table Analyses Based on Data in Table 6.2

\begin{tabular}{|c|c|c|c|c|}
\hline \multirow{3}{*}{$\begin{array}{l}\text { Assumed } \\
\text { Threshold } \\
\text { Level } \\
\text { (GI) }\end{array}$} & \multicolumn{2}{|c|}{$\begin{array}{c}\text { Proportion Above } \\
\text { Threshold }\end{array}$} & & \multirow[b]{3}{*}{ Probability } \\
\hline & \multicolumn{2}{|c|}{$\begin{array}{c}\text { Number of Homeowners } \\
(\text { in 1000s }) \\
(n=881)\end{array}$} & & \\
\hline & $\begin{array}{l}\text { Loan } \\
(n=86)\end{array}$ & $\begin{array}{c}\text { Other Sources } \\
(n=795)\end{array}$ & $x^{2}$ & \\
\hline .01 & $81 \%$ & $72 \%$ & No $\mathrm{si}$ & ficance \\
\hline .02 & 81 & 55 & 7.410 & 0.006 \\
\hline .03 & 77 & 46 & 10.104 & 0.001 \\
\hline .04 & 72 & 37 & 13.938 & 0.000 \\
\hline .05 & 67 & 34 & 12.817 & 0.000 \\
\hline .06 & 65 & 30 & 14.783 & 0.000 \\
\hline .08 & 51 & 20 & 13.835 & 0.000 \\
\hline .10 & 43 & 16 & 13.086 & 0.000 \\
\hline .12 & 38 & 12 & (a) & \\
\hline .15 & 26 & 10 & (a) & \\
\hline .20 & 21 & 5 & (a) & \\
\hline
\end{tabular}

(a) Chi-square test could not be conducted.

- If the threshold level was set at the $2 \%$ level, the proportion of respondents who financed with loans above the threshold level was $81 \%$, compared to $55 \%$ for those who financed with other sources. With chi-squares computed at 7.41 and 1 degree of freedom, the test is significant at the $1 \%$ significance level. This implies that the $2 \%$ level meets the condition of a threshold. Similar interpretations can be made of the results for the potential threshold levels of $3 \%$, $4 \%, 5 \%, 6 \%, 8 \%$, and $10 \%$.

- If the potential threshold level was set at $12 \%$ and over, then the conditions for a valid chi-square test were no longer met and the test could not be done.

Since the $2 \%$ level of investment to income ratio was the lowest potential threshold level for which the chi-square test was significant, it can be viewed 
as the threshold level according to the decision rule adopted for this analysis. This case is underlined in Table 6.3. It is possible that the true threshold level falls somewhere between $1 \%$ and $2 \%$ and that it can be identified by applying the same procedure as was done above.

\subsection{DEMOGRAPHIC AND OTHER INFLUENCES ON THE THRESHOLD LEVEL}

To determine whether the threshold level of conservation investment is affected by demographic and other factors, the 2 by 2 contingency table analyses can be applied to the data by controlling for the relevant variables. Variables controlled include education, household income, age, occupation, gender, amount of investment class, preferences concerning the financing of purchases of major consumer products, and the respondent's self perception with respect to spending for today. However, the nature of the sample data and the limited size of the subsamples severely restricted the application of the chi-square test. For this reason it is necessary to digress on the size of the subsamples.

Table $6.4 a$ presents the unweighted frequencies of subsamples with respect to the control variables. Among the 766 homeowners in the sample, only 326 responded to the detailed income questions and indicated that they have made specific amount of investment in energy conservation measures. When the question of how the respondent financed their investment was introduced, the effective sample size was further reduced to 316 . Of these, only 29 or about $9 \%$ financed with loans. As a result, the introduction of one additional level of classification further lowers the number of households which financed with loans for individual subgroups. For example, among the 54 households with income less than $\$ 16,000$, there were only 2 households which financed their investments with loans. Similarly, there were only 2, out of 38 respondents agreeing with the statement that I pretty spend for today and let tomorrow bring what it will, who financed with loans. Out of 38 respondents who preferred monthly installments over saving first, only 3 financed with loans. Other examples of only a few observations of households which financed with loans were 5 each for blue-collar occupations, and for those who were over 
TABLE 6.4a. Unweighted Frequencies for Conservation Investment Made During 1983-85 by Financing Source and by Demographic and Other Factor

Groups

Total Sample

(\%)

By Education

High school or less

Some college or more

By Household Income

Less than $\$ 16,000$

$\$ 16,000-\$ 30,000$

Over $\$ 30,000$

\begin{tabular}{|c|c|c|}
\hline \multicolumn{2}{|c|}{$\begin{array}{l}\text { Homeowners } \\
\text { Financed With }\end{array}$} & \multirow[b]{2}{*}{ Sum } \\
\hline Loans & $\begin{array}{l}\text { Other } \\
\text { Sources }\end{array}$ & \\
\hline $\begin{array}{l}29 \\
9 \%\end{array}$ & $\begin{array}{l}287 \\
91 \%\end{array}$ & $\begin{array}{l}316 \\
100 \%\end{array}$ \\
\hline
\end{tabular}

9

20

131

156

140

176

$2 \quad 52$

109

$10 \quad 126 \quad 136$

54

126

By Age

Under 34 years

35 - 54 years

Over 55 years

By Occupation

White collar

Blue collar

By Gender

Male

Fema le

9

15

5

82

126

76

91

141

81

18

135

153

5

70

75

9

119

128

20

168

188

By Amount of Investment

$\$ 1-\$ 500$

$\$ 501-\$ 1,000$

$\$ 1,001-\$ 2,000$

Over $\$ 2,000$

14

6
4
5
14

136

50

46

55

142

54

51

69

Pay Cash Now Versus Monthly Installment Prefer pay cash now Prefer monthly installment

26

3

250

35

276

38

Monthly Installment Versus Save First Prefer monthly installment Prefer save first

11

74

202

85

18

220

Statement "I presently spend for today and let tomorrow bring what it will"

Agree

Disagree

2

12

36

175

38

187 
55 years old; 6 for households whose past investment was in the range of $\$ 1$ to $\$ 500$ range; 9 each for respondents with at most high-school education, for those who were under 34 years of age, and for male respondents; and 4 and 5 respectively, for households whose past conservation investment fell in the $\$ 501$ to $\$ 1000$ to $\$ 2000$ range. The small number of observations in the subsamples did not make continuous frequency distributions and precluded the use of the chi-square test. Hence, the following discussion covers only those cases with sufficiently large numbers of observations of households financing with loans, as determined by Table $6.4 \mathrm{a}$.

Table 6.4b presents the corresponding population weighted frequencies of subsamples. Table 6.5 summarizes the results of detailed contingency table analyses applied to the individual cases, using population weighted data. For example, take the case of respondents with at least some college education (first line in Table 6.5). Out of the 504,000 homeowners who were in this category, 65,000 (or about 13\%) financed with loans, the other $87 \%$ paid for their conservation investments with current income, savings, or other sources. The information in the table indicates that the threshold level of conservation investment to income ratio was identified at the $2 \%$ level and the chi-square test for the 2 by 2 contingency table analysis at this threshold level is significant at the 1\% significance (or 99\% confidence level). Table 6.6 is referenced to provide more details on this result.

Table 6.6 is identical in construction to Table 6.3 for the total sample (without controlling for demographic or other variables). Hence, Table 6.6 can be interpreted in the same manner as described above for Table 6.3. Table 6.6 indicates that at the $1 \%$ investment to income ratio level, $80 \%$ of those who financed with loans were above that level and $67 \%$ of those who paid with other sources are above that level, but the chi-square test was not significant. At the $2 \%$ potential threshold level, the corresponding proportions of households above that level were $80 \%$ and $46 \%$ respectively and the test was significant. The test continued to be significant at the $3 \%, 4 \%, 5 \%$, and $6 \%$ potential threshold level. At $8 \%$ potential threshold level and above, the conditions of the chi-square test were longer met, and the test could not be done. 
TABLE 6.4b. Weighted Frequencies for Conservation Investment Made During 1983-85 by Financing Source and by Demographic and Other Factor

\begin{tabular}{|c|c|c|c|}
\hline \multirow[b]{2}{*}{ Groups } & \multicolumn{2}{|c|}{$\begin{array}{l}\text { Homeowners } \\
\text { (in 1000s) } \\
\text { Financed With }\end{array}$} & \multirow[b]{2}{*}{ Sum } \\
\hline & Loans & Sources & \\
\hline $\begin{array}{c}\text { Total Population } \\
(\%)\end{array}$ & $\begin{array}{l}86 \\
10 \%\end{array}$ & $\begin{array}{l}795 \\
90 \%\end{array}$ & $\begin{array}{l}881 \\
100 \%\end{array}$ \\
\hline
\end{tabular}

By Education

High school or less

22

355

377

Some college or more

65

440

504

By Household Income

Less than $\$ 16,000$

$\$ 16,000-\$ 30,000$

Over $\$ 30,000$

$\begin{array}{rll}5 & 136 & 140 \\ 47 & 289 & 337 \\ 34 & 370 & 404\end{array}$

By Age

Under 34 years

35 - 54 years

25

46

225

250

Over 55 years

16

342

387

232

By Occupation

White collar

Blue collar

57

97

364

421

9

185

194

By Gender

Male

Female

29

333

362

57

462

519

By Amount of Investment

$\$ 1-\$ 500$

$\$ 501-\$ 1,000$

$\$ 1,001-\$ 2,000$

Over $\$ 2,000$

17

386

132

125

152

403

140

144

149

Pay Cash Now Versus Monthly Installment

Prefer pay cash now

Prefer monthly installment

79

7

701

780

97

Monthly Installment Versus Save First Prefer monthly installment

Prefer save first

Statement "I presently spend for today and let tomorrow bring what it will"

Agree

Disagree 
TABLE 6.5. Summary Results on Threshold Levels of Conservation Investment of Different Cases by Demographic and Other Variable

\begin{tabular}{|c|c|c|c|c|c|c|}
\hline Case & $\begin{array}{c}\text { Threshold } \\
\text { Level: } \\
\text { Investment as } \\
q \text { of Income } \\
\end{array}$ & $\begin{array}{c}\text { Size of } \\
\text { Subsample } \\
\text { (in 1000s) } \\
\end{array}$ & $\begin{array}{c}\text { Finan } \\
\text { Number } \\
(\text { in } \\
1000 \mathrm{~s})\end{array}$ & $\begin{array}{l}\text { hose who } \\
\text { ed With Loans } \\
\text { As क of Total } \\
\text { Observation } \\
\text { in the Group }\end{array}$ & $\begin{array}{c}\text { Significant } \\
\text { Level for the } \\
\text { Chi-Square Test } \\
\end{array}$ & Reference \\
\hline $\begin{array}{l}\text { At least some } \\
\text { college education }\end{array}$ & $2 \%$ & 504 & 65 & $13 \%$ & $1 x$ & Table 6.6 \\
\hline $\begin{array}{l}\text { Household Income } \\
\text { between } \$ 16,000 \\
\text { and } \$ 30,000\end{array}$ & $2 \%$ & 337 & 47 & $14 \%$ & 18 & $T a b l e 6.7$ \\
\hline $\begin{array}{l}\text { Respondents between } \\
35 \text { and } 54 \text { years of } \\
\text { age }\end{array}$ & $2 \%$ & 387 & 46 & $21 \%$ & $1 \%$ & Table 6.8 \\
\hline $\begin{array}{l}\text { White collar } \\
\text { occupation }\end{array}$ & $2 \%$ & 421 & 57 & $14 \%$ & $5 \%$ & Table 6.9 \\
\hline Female respondents & 28 & 519 & 57 & $11 \%$ & 18 & Table 6.10 \\
\hline $\begin{array}{l}\text { Respondents whose } \\
\text { investment during } \\
1983-85 \text { was over } \\
\$ 2,000\end{array}$ & (a) & 192 & 42 & $22 \%$ & -- & Table 6.11 \\
\hline $\begin{array}{l}\text { Respondents who } \\
\text { prefer paying cash } \\
\text { now over monthly } \\
\text { installment }\end{array}$ & $2 q$ & 780 & 79 & $10 \%$ & $5 \%$ & Table 6.12 \\
\hline $\begin{array}{l}\text { Respondents who } \\
\text { prefer saving first } \\
\text { over monthly } \\
\text { Installment }\end{array}$ & $3 x$ & 605 & 57 & $9 \%$ & $5 \%$ & Table 6.13 \\
\hline $\begin{array}{l}\text { Respondents who } \\
\text { disagree with the } \\
\text { spending for today } \\
\text { statement }\end{array}$ & (a) & 490 & 31 & $6 \%$ & -- & Table 6.14 \\
\hline
\end{tabular}

(a) Cannot be identified.

According to the decision rule discussed earlier, $2 \%$ was thus identified as the threshold level for the case of respondents who have at least some college education.

The interpretation of the other cases in Table 6.5 can be made in a similar manner as described above. The details of the individual cases can be 
TABLE 6.6. Summary Results of 2 by 2 Contingency Table Analyses for Respondents with at Least Some college Education

\begin{tabular}{|c|c|c|c|c|}
\hline \multirow{2}{*}{$\begin{array}{c}\text { As sumed } \\
\text { Threshold } \\
\text { Level } \\
\end{array}$} & \multicolumn{2}{|c|}{$\begin{array}{l}\text { Proportion } \\
\text { Above Threshold } \\
\text { Number of Homeowners } \\
\text { (in 1000s) }(n=504)\end{array}$} & & \multirow[b]{2}{*}{ Probability } \\
\hline & $\begin{array}{l}\text { Loan } \\
(n=65) \\
\end{array}$ & $\begin{array}{c}\text { Other Sources } \\
(n=440)\end{array}$ & $x^{2}$ & \\
\hline .01 & $80 \%$ & $67 \%$ & No $s$ & ificance \\
\hline .02 & $\underline{80}$ & $\underline{46}$ & 9.039 & .003 \\
\hline .03 & 77 & 39 & 11.181 & .000 \\
\hline .04 & 70 & 31 & 12.359 & .000 \\
\hline .05 & 67 & 28 & 13.360 & .000 \\
\hline .06 & 67 & 24 & 17.517 & .000 \\
\hline .08 & 47 & 16 & (a) & \\
\hline .10 & 37 & 13 & (a) & \\
\hline .12 & 30 & 9 & (a) & \\
\hline .15 & 23 & 7 & (a) & \\
\hline .20 & 18 & 5 & (a) & \\
\hline
\end{tabular}

(a) Chi-square test could not be done.

found in Tables 6.6 through 6.14. The results of the analyses on the influences of demographic and other variables on the threshold level are highlighted below:

- Out of the 9 cases considered, the threshold level was identified at the $2 \%$ level of investment to income ratio for six cases. These six cases involve respondents who had at least some college education, whose household income was between $\$ 16,000$ and $\$ 30,000$, who were between 35 and 54 years of age, who were female, whose occupation was white-collar, or who preferred to pay cash now rather than monthly installments when paying for the purchase of major consumer products. The confidence level of the chi-square tests associated with these cases were at the 99\% level for 4 of the 6 cases and at the $95 \%$ level for the other two. 
TABLE 6.7. Summary. Results of 2 by 2 Contingency Table Analyses for Respondents with Household Income Between $\$ 16,000$ and $\$ 30,000$

\begin{tabular}{|c|c|c|c|c|}
\hline \multirow{2}{*}{$\begin{array}{c}\text { Assumed } \\
\text { Threshold } \\
\text { Level } \\
\end{array}$} & $\begin{array}{r}\text { Abc } \\
\text { Numbe } \\
\text { (in }\end{array}$ & $\begin{array}{l}\text { ortion } \\
\text { Threshold } \\
\text { Homeowners } \\
\text { fs }(n=337)\end{array}$ & \multirow[b]{2}{*}{$x^{2}$} & \multirow[b]{2}{*}{ Probability } \\
\hline & $\begin{array}{l}\text { Loan } \\
(n=47) \\
\end{array}$ & $\begin{array}{c}\text { Other Sources } \\
(n=289)\end{array}$ & & \\
\hline .01 & $93 \%$ & $79 \%$ & (a) & \\
\hline .02 & $\underline{93}$ & 57 & 7.856 & .005 \\
\hline .03 & 86 & 47 & 8.241 & .004 \\
\hline .04 & 86 & 38 & 13.255 & .000 \\
\hline .05 & 81 & 34 & 13.073 & .000 \\
\hline .06 & 78 & 31 & 13.190 & .000 \\
\hline .08 & 52 & 20 & (a) & \\
\hline .10 & 41 & 15 & (a) & \\
\hline .12 & 41 & 8 & (a) & \\
\hline .15 & 30 & 8 & (a) & \\
\hline .20 & 23 & 4 & (a) & \\
\hline
\end{tabular}

(a) Chi-square test could not be done.

- In the case of respondents who preferred saving first over paying by monthly installments when purchasing major consumer products, the threshold level of investment to income ratio was identified at the $3 \%$ level. The chi-square test for this case was significant at the 95\% confidence level.

- The threshold level cannot be identified for the other two cases involving respondents whose investment was over $\$ 2000$ and those who disagreed with the statement that "I pretty much spend for today and let tomorrow bring what it will." In these two cases, the number of observations (unweighted) for households financing with loans were lowest among the 9 cases considered: 14 and 12 respectively. In the 
TABLE 6.8. Summary Results of 2 by 2 Contingency Table Analyses for Respondents Who Are in the Age Group 35-54 Years 01d

\begin{tabular}{|c|c|c|c|c|}
\hline \multirow{2}{*}{$\begin{array}{c}\text { Assumed } \\
\text { Threshold } \\
\text { Level } \\
\end{array}$} & \multicolumn{2}{|c|}{$\begin{array}{l}\text { Proportion } \\
\text { Above Threshold } \\
\text { Number of Homeowners } \\
\text { (in 1000s) }(n=387)\end{array}$} & \multirow[b]{2}{*}{$x^{2}$} & \multirow[b]{2}{*}{ Probability } \\
\hline & $\begin{array}{l}\text { Loan } \\
(n=46) \\
\end{array}$ & $\begin{array}{c}\text { Other Sources } \\
(n=342)\end{array}$ & & \\
\hline .01 & $90 \%$ & $68 \%$ & (a) & \\
\hline 02 & 83 & 49 & 6.594 & .010 \\
\hline .03 & 79 & 41 & 7.840 & .005 \\
\hline .04 & 79 & 31 & 13.663 & .000 \\
\hline .05 & 74 & 28 & 13.240 & .000 \\
\hline .06 & 70 & 25 & 13.189 & .000 \\
\hline .08 & 64 & 22 & (a) & \\
\hline .10 & 64 & 17 & (a) & \\
\hline .12 & 53 & 12 & (a) & \\
\hline .15 & 32 & 10 & (a) & \\
\hline .20 & 32 & 4 & (a) & \\
\hline
\end{tabular}

(a) Chi-square test could not be done.

case of respondents who invested over $\$ 2000$ during 1983-85, the effective size of the subsample (unweighted) was also small: 69 compared to 126 at the lowest for the other 8 cases (Table 6.4a).

To summarize, the threshold level identified for most of cases considered was at the $2 \%$ level of investment to income ratio, the same as that identified for the total sample without controlling for demographic and other variables. In one case involving respondents who prefer saving first over monthly installments in funding the purchase of major consumer products, the threshold level was identified at the $3 \%$ level. No threshold level was identified for the other two cases considered: one involving respondents whose investment during 1983-85 was over $\$ 2000$ and the other involving respondents who disagree with the statement that "I pretty much spend for today and let tomorrow bring what it will." Hence, it can be tentatively concluded that the threshold level of 
TABLE 6.9. Summary Results of 2 by 2 Contingency Table Analyses for Respondents with White-Collar Occupation

Proportion

Above Threshold

Number of Homeowners

Assumed

Threshold

\begin{tabular}{cc} 
(in 1000s) & $(n=421)$ \\
$\frac{\text { Loan }}{(n=57)}$ & $\begin{array}{c}\text { Other Sources } \\
(n=364)\end{array}$ \\
\hline $83 \%$ & $\frac{68 \%}{87}$
\end{tabular}

$\frac{x^{2}}{\text { No Significance }}$

.01

$\frac{77}{71}$

$\frac{49}{42}$

$\frac{5.335}{5.585}$

$\frac{.021}{.018}$

.03

63

36

5.277

.022

.05

59

32

5.614

.018

.06

58

35

8.369

.004

.08

37

19

(a)

.10

28

16

(a)

.12

20

11

(a)

.15

15

10

(a)

.20

15

4

(a)

(a) Chi-square test could not be done.

conservation spending above which the consumer tends to finance with loans does not vary with demographic variables; rather, it remains fairly constant at $2 \%$ for those cases considered.

\subsection{ESTIMATION OF LOGIT MODELS}

Table 6.15 presents the results of three different sets of logistic regression estimates: 1) Total sample; 2) using the threshold level of investment to income ratio $(G I)=.02$ as the dividing line, the subsample of those with GI less than or equal to .02; and 3 ) the subsample of those with GI greater than .02 . In Case 1 for the total sample, estimates of both the intercept term and slope parameters are statistically significant. In this formulation, the intercept term simply determines the estimated probability of financing with loans if the investment to income ratio is equal to zero. The slope 
TABLE 6.10. Summary Results of 2 by 2 Contingency Table Analyses for Female Respondents

\begin{tabular}{|c|c|c|c|c|}
\hline \multirow{2}{*}{$\begin{array}{c}\text { As sumed } \\
\text { Threshold } \\
\text { Level } \\
\end{array}$} & $\begin{array}{r}\mathrm{Ab} \\
\text { Numb } \\
(\mathrm{in} \\
\end{array}$ & $\begin{array}{l}\text { ortion } \\
\text { Threshold } \\
\text { f Homeowners } \\
\text { Os) }(n=519)\end{array}$ & \multirow[b]{2}{*}{$x^{2}$} & \multirow[b]{2}{*}{ Probability } \\
\hline & $\begin{array}{l}\text { Loan } \\
(n=57)\end{array}$ & $\begin{array}{c}\text { Other Sources } \\
(n=462)\end{array}$ & & \\
\hline .01 & $95 \%$ & $75 \%$ & (a) & \\
\hline .02 & 95 & 58 & 10.152 & .001 \\
\hline .03 & 92 & 50 & 12.331 & .000 \\
\hline .04 & 84 & 39 & 14.541 & .000 \\
\hline .05 & 76 & 36 & 12.294 & .000 \\
\hline .06 & 74 & 31 & 14.083 & .000 \\
\hline .08 & 66 & 19 & (a) & \\
\hline .10 & 56 & 15 & (a) & \\
\hline .12 & 56 & 12 & (a) & \\
\hline .15 & 39 & 9 & (a) & \\
\hline .20 & 31 & 6 & (a) & \\
\hline
\end{tabular}

(a) Chi-square test could not be done.

estimate captures the changes in the probability of financing with loans as the investment to income ratio changes. For Case 2 for the subsample with GI less than or equal to .02 (or investment equal to $2 \%$ of annual household income), the estimate for coefficient a is highly significant while the estimate for coefficient $b$ for the slope is not significant. This suggests that below the $2 \%$ threshold level, the probability of financing with loans is not affected by $G I$, the investment to income ratio. Hence, the predicted probability can be fixed at .027 , implied when the estimate for $b=-3.592$. In Case 3 for subsample with GI above .02, the estimates for both a and b are significant. The slope estimate is 4.505 which is smaller than the estimate of 6.422 for Case 1. 
TABLE 6.11. Summary Results of 2 by 2 Contingency Table Analyses for Respondents Whose 1983-85 Investment was Over $\$ 2,000$

\begin{tabular}{|c|c|c|c|c|c|}
\hline \multirow{2}{*}{$\begin{array}{c}\text { Assumed } \\
\text { Threshold } \\
\text { Level } \\
\end{array}$} & \multicolumn{2}{|c|}{$\begin{array}{l}\text { Proportion } \\
\text { Above Threshold } \\
\text { Number of Homeowners } \\
\text { (in 1000s) }(n=194)\end{array}$} & \multirow{2}{*}{\multicolumn{2}{|c|}{$x^{2}$}} & \multirow[b]{2}{*}{ Probability } \\
\hline & $\begin{array}{l}\text { Loan } \\
(n=42)\end{array}$ & $\begin{array}{c}\text { Other Sources } \\
(n=152)\end{array}$ & & & \\
\hline .01 & $100 \%$ & $100 \%$ & (a) & & \\
\hline .02 & 100 & 100 & (a) & & \\
\hline .03 & 100 & 100 & (a) & & \\
\hline .04 & 100 & 98 & (a) & & \\
\hline .05 & 100 & 98 & (a) & & \\
\hline .06 & 100 & 92 & (a) & & \\
\hline .08 & 100 & 82 & (a) & & \\
\hline .10 & 84 & 67 & (a) & & \\
\hline .12 & 73 & 50 & & No & Significance \\
\hline .15 & 50 & 45 & & No & Significance \\
\hline .20 & 42 & 26 & (a) & & \\
\hline
\end{tabular}

(a) Chi-square test could not be done.

Thus, combining cases 2 and 3 to represent the probability of a household financing its conservation investment with loans, the following function is derived:

$$
P \text { (Loans) }=\left\{\begin{array}{l}
0.27 \text { if } G I<0.2 \\
\frac{\operatorname{EXP}(-2.452+4.505 * G I)}{1+\operatorname{EXP}(-2.452+4.505 \star G I)} \text { if } G I>.02 .
\end{array}\right.
$$

Figure 6.1 depicts the plot of this probability distribution. Note that although the actual frequencies were not plotted, there are 67 points between $G I=0$ and $G I=0.02$. 
TABLE 6.12. Summary Results of 2 by 2 Contingency Table Analyses for Respondents Who Prefer Paying Cash Now Over Monthly Installments

\begin{tabular}{|c|c|c|c|c|}
\hline \multirow{2}{*}{$\begin{array}{c}\text { As sumed } \\
\text { Threshold } \\
\text { Level } \\
\end{array}$} & \multicolumn{2}{|c|}{$\begin{array}{l}\text { Proportion } \\
\text { Above Threshold } \\
\text { Number of Homeowners } \\
\text { (in 1000s) }(n=780)\end{array}$} & \multirow[b]{2}{*}{$x^{2}$} & \multirow[b]{2}{*}{ Probability } \\
\hline & $\begin{array}{l}\text { Loan } \\
(n=79)\end{array}$ & $\begin{array}{c}\text { Other Sources } \\
(n=701) \\
\end{array}$ & & \\
\hline .01 & $84 \%$ & $73 \%$ & No & Significance \\
\hline .02 & 80 & 55 & 6.176 & .013 \\
\hline .03 & 75 & 45 & 8.665 & .003 \\
\hline .04 & 69 & 36 & 11.476 & .001 \\
\hline .05 & 67 & 33 & 12.344 & .000 \\
\hline .06 & 65 & 29 & 14.133 & .000 \\
\hline .08 & 53 & 19 & 16.304 & .000 \\
\hline .10 & 44 & 15 & (a) & \\
\hline .12 & 39 & 10 & (a) & \\
\hline .15 & 26 & 8 & (a) & \\
\hline .20 & 22 & 5 & (a) & \\
\hline
\end{tabular}

(a) Chi-square test could not be done.

\subsection{DISCUSSION}

Using the data from household investments in energy conservation made during the 1983-85 period and 2 by 2 contingency table analysis, it has been concluded that there exists a threshold level of conservation investment to household income ratio above which consumers are more likely to finance their investments with loans. Thus, Hypothes is $3 A$ is confirmed by the data. Without controlling for demographic or other variables, this threshold level was tentatively identified at the $2 \%$ level of conservation investment to household income ratio. (a) Controlling for demographic or attitudinal variables, the threshold level was also identified at the $2 \%$ level for six of the nine cases

(a) Note again that the $2 \%$ level is computed by dividing the amount of conservation investment over the two-year period of 1983-1985 by the annual household income. The actual burden on the household would be only about $1 \%$ of the two-year income. 
TABLE 6.13. Summary Results of 2 by 2 Contingency Table Analyses for Respondents Who Prefer Saving First Over Monthly Installments

\begin{tabular}{|c|c|c|c|c|}
\hline \multirow{2}{*}{$\begin{array}{c}\text { Assumed } \\
\text { Threshold } \\
\text { Level } \\
\end{array}$} & \multicolumn{2}{|c|}{$\begin{array}{l}\text { Proportion } \\
\text { Above Threshold } \\
\text { Number of Homeowners } \\
\text { (in 1000s) (n=605) }\end{array}$} & \multirow[b]{2}{*}{$x^{2}$} & \multirow[b]{2}{*}{ Probability } \\
\hline & $\begin{array}{l}\text { Loan } \\
(n=57)\end{array}$ & $\begin{array}{c}\text { Other Sources } \\
(n=548)\end{array}$ & & \\
\hline .01 & $77 \%$ & $73 \%$ & (a) & \\
\hline .02 & 72 & 57 & \multicolumn{2}{|c|}{ № Significance } \\
\hline .03 & 72 & $\underline{46}$ & 4.808 & .028 \\
\hline .04 & 64 & 34 & 6.611 & .010 \\
\hline .05 & 60 & 30 & 7.087 & .008 \\
\hline .06 & 58 & 27 & 7.774 & .005 \\
\hline .08 & 41 & 16 & (a) & \\
\hline .10 & 38 & 13 & (a) & \\
\hline .12 & 38 & 9 & (a) & \\
\hline .15 & 33 & 7 & (a) & \\
\hline .20 & 27 & 5 & (a) & \\
\hline
\end{tabular}

(a) Chi-square test could not be done.

considered. In one case involving respondents who prefer saving first over monthly installments in funding the purchase of major consumer products, the threshold level is identified at the $3 \%$ level. No threshold level was identified for the other two cases: one involving respondents whose investment during 1983-85 was over $\$ 2000$ and the other involving respondents who disagree with the statements that "I pretty much spend for today and let tomorrow bring what it will." Thus Hypothesis $3 B$ is not confirmed. Combined, it can be tentatively concluded that Hypothes is No. 3 is only partially confirmed: There is a threshold level of conservation spending above which consumers are more likely to finance with loans and the threshold is at the $2 \%$ level for consumers in the Northwest. On the other hand, available data do not support the idea that the threshold level varies by demographics.

It should be noted, however, that this conclusion was based on a sample which included only 29 homeowners who financed their investments in ECMs with 
TABLE 6.14. Summary Results of 2 by 2 Contingency Table Analyses for Respondents Who Disagree with the Statement "I pretty much spend for today and let tomorrow bring what it will"

\begin{tabular}{|c|c|c|c|c|}
\hline \multirow{2}{*}{$\begin{array}{c}\text { Assumed } \\
\text { Threshold } \\
\text { Level } \\
\end{array}$} & \multicolumn{2}{|c|}{$\begin{array}{l}\text { Proportion } \\
\text { Above Threshold } \\
\text { Number of Homeowners } \\
\text { (in 1000s) }(n=490)\end{array}$} & \multirow[b]{2}{*}{$x^{2}$} & \multirow[b]{2}{*}{ Probability } \\
\hline & $\begin{array}{l}\text { Loan } \\
(n=31)\end{array}$ & $\begin{array}{c}\text { Other Sources } \\
(n=459)\end{array}$ & & \\
\hline .01 & $84 \%$ & $70 \%$ & (a) & \\
\hline .02 & 74 & 52 & No & significance \\
\hline .03 & 68 & 46 & No & significance \\
\hline .04 & 68 & 37 & (a) & \\
\hline .05 & 62 & 34 & (a) & \\
\hline .06 & 62 & 31 & (a) & \\
\hline .08 & 52 & 21 & (a) & \\
\hline .10 & 47 & 16 & (a) & \\
\hline .12 & 32 & 11 & (a) & \\
\hline .15 & 32 & 10 & (a) & \\
\hline .20 & 26 & 7 & (a) & \\
\hline
\end{tabular}

(a) Chi-square test could not be done.

TABLE 6.15. Alternative Estimates of Logit Model for Total Sample(a)

\begin{tabular}{cccccc}
$\begin{array}{c}\text { Equation/ } \\
\text { Parameters }\end{array}$ & $\begin{array}{c}\text { Parameter } \\
\text { Estimate }\end{array}$ & Standard Error & & Chi-Square & Probability \\
\cline { 1 - 2 } Total Sample Combined $(n=152)$ & & & \\
a & -3.020 & .227 & 177.23 & 0.0001 \\
b & 6.422 & 1.391 & 21.31 & 0.0001
\end{tabular}

Subsample Where GI $\leqslant .02(n=67)$
a
$-3.592$
28.768
.445
56.373
65.1
0.0001
0.26
0.610

Subsample where GI >.02 ( $n=85)$
a
-2.452
4.505
0.317
1.565
60.03
8.30
0.0001
0.004

(a) Estimated with relative weights. 


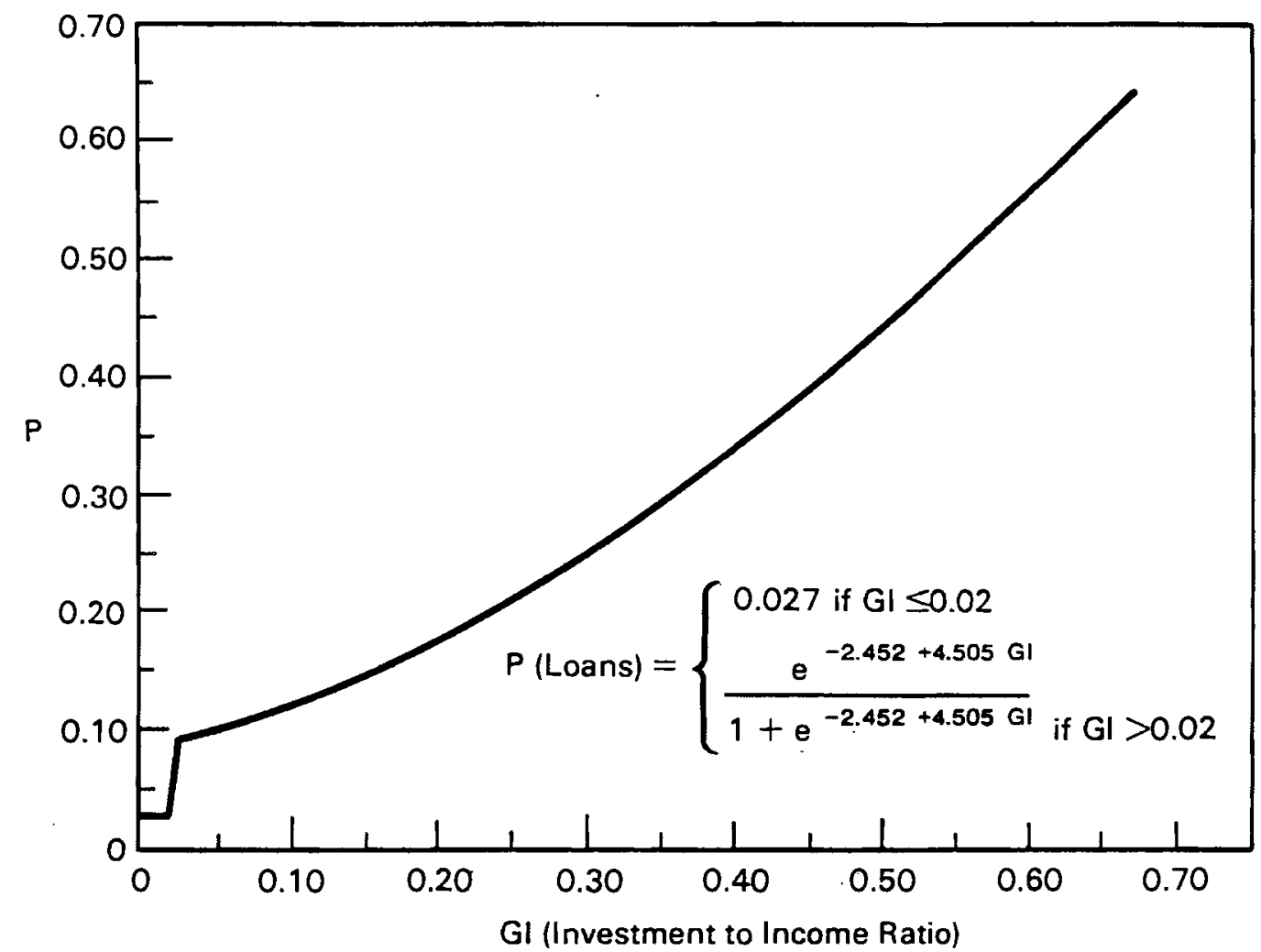

FIGURE 6.1. Plot of the Estimated Logit Model of the Probability of Financing with Loans with the Threshold Level at $2 \%$ of Household Income

loans, out of an effective sample of 316 homeowners (unweighted). The sma11 number of households financing with loans severely restricted the applicability of the 2 by 2 contingency table analysis to subsamples when the individual demographic variables were controlled.

The logit model was used to estimate the probability distribution of households financing with loans. Assuming that the $2 \%$ threshold level identified by the contingency table analysis is true, the logit analysis suggests that below the threshold level, the investment to income ratio does not affect the probability of households financing with loans.

Given the 1983-85 data on energy conservation investments and the financing sources, the threshold level of spending on installing energy conservation measures as a proportion of household income at which consumers became more likely to finance with bank or utility loans was identified at $2 \%$. This implies an amount of $\$ 400$ for respondents whose household income is $\$ 20,000$; and $\$ 800$ for respondents whose income is $\$ 40,000$. During the 1983-85 period, 
conservation investment per homeowner averaged about $\$ 1,570$ for those who invested (Fang, et al. 1986, p. 5.11). This average investment far exceeded the threshold level of investment even for households whose annual income is $\$ 40,000$. Since conservation investments involve installation of the ECMs such as weatherproofing, ceiling, wall, and floor insulation, storm doors, storm windows, setback or automatic thermostats, heat pump furnaces, heat pump water heaters, solar panels for water heating, wood stoves, and fireplace inserts, installation of several items at the same time is likely to result in total spending exceeding the threshold level. Therefore, many consumers might be looking for ways to finance with loans. These considerations suggest conservation financing programs such as bank loans and utility loans may be important in promoting conservation investments in the near future. This is all the more true if the funding sources for potential future investments explained in Chapter 3 are true. There, it was found that, while only about $10 \%$ of respondents said that the most important sources of funds for investment made in 1983-85 was bank and utility loans, about $50 \%$ of the respondents indicated that they would finance potential future investment with loans. 
APPENDIX A

SUPPORTING TABLES FOR CHAPTER 4 


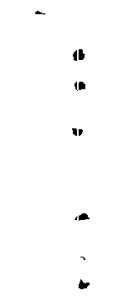


TABLE A.1. Financing Sources of Conservation Investment During 1984-85 by Gender

\begin{tabular}{lcc} 
& $\begin{array}{c}\text { Number of Homeowners } \\
\text { (in 1000s) } \\
\text { Gender }(n=1755)\end{array}$ \\
\cline { 3 - 3 } $\begin{array}{l}\text { Respondents Who } \\
\text { Financed With }\end{array}$ & $\frac{\begin{array}{c}\text { Male } \\
(n=638)\end{array}}{12 \%}$ & $\begin{array}{c}\text { Female } \\
(n=1116)\end{array}$ \\
\hline Loans & 63 & $9 \%$ \\
Current Income & 18 & 65 \\
Savings & 7 & 6 \\
Other Sources & & 20
\end{tabular}

No significance.

TABLE A.2. Financing Sources of Potential Future Conservation Investment by Gender

\begin{tabular}{|c|c|c|}
\hline \multirow[b]{2}{*}{$\begin{array}{l}\text { Respondents Who } \\
\text { Would Finance With }\end{array}$} & \multicolumn{2}{|c|}{$\begin{array}{c}\text { Number of Homeowners } \\
\text { (in } 1000 \mathrm{~s}) \\
\text { Gender }(n=1531)\end{array}$} \\
\hline & $\begin{array}{l}\text { Male } \\
(n=591) \\
\end{array}$ & $\begin{array}{l}\text { Female } \\
(n=940)\end{array}$ \\
\hline Loans & $52 \%$ & $49 \%$ \\
\hline Current Income & 13 & 12 \\
\hline Savings & 9 & 9 \\
\hline Other Sources & 26 & 31 \\
\hline
\end{tabular}


TABLE A.3. Financing Sources of Conservation Investment During $1984-85$ by Income

Number of Homeowners (in 1000s)

Respondents Who Household Income $(n=1624)$

Financed With Under $\$ 16,000$ $\$ 16,000-\$ 30,000$

$\frac{(n=363)}{5 \%}$
$(n=593)$ Over $\$ 30,000$

Current Income 68 $13 \%$ $11 \%$

Savings

18

59

66

Other Sources

8

22

16

5

6

No significance.

TABLE A.4. Financing Sources of Potential Future Conservation Investment by Income

\begin{tabular}{|c|c|c|c|}
\hline \multirow[b]{2}{*}{$\begin{array}{l}\text { Respondents Who } \\
\text { Would Financed With }\end{array}$} & \multicolumn{3}{|c|}{$\begin{array}{l}\text { Number of Homeowners (in 1000s) } \\
\text { Household Income }(n=1423)\end{array}$} \\
\hline & $\begin{array}{l}\text { Under } \$ 16,000 \\
\quad(n=272) \\
\end{array}$ & $\begin{array}{c}\begin{array}{c}\$ 16,000-\$ 30,000 \\
(n=519)\end{array} \\
\end{array}$ & $\begin{array}{l}\text { Over } \$ 30,000 \\
(n=632) \\
\end{array}$ \\
\hline Loans & $44 \%$ & $51 \%$ & $56 \%$ \\
\hline Current Income & 14 & 9 & 12 \\
\hline Savings & 10 & 8 & 8 \\
\hline Other Sources & 32 & 32 & 24 \\
\hline
\end{tabular}

No significance. 
TABLE A.5. Financing Sources of Conservation Investment During 1984-85 by Occupation of Respondent

\begin{tabular}{lcc} 
Respondents Who & $\begin{array}{c}\text { Number of Homeowners } \\
\text { (in 1000s) } \\
\text { Occupation }\end{array}$ \\
$\begin{array}{l}\text { Financed With } \\
\text { Loans }\end{array}$ & $\begin{array}{c}\text { White Collar } \\
(n=757)\end{array}$ & $\begin{array}{c}\text { Blue Collar } \\
(n=380)\end{array}$ \\
\cline { 2 - 3 } Current Income & $14 \%$ & $7 \%$ \\
Savings & 62 & 65 \\
Other Sources & 16 & 22 \\
& 8 & 6
\end{tabular}

No significance.

TABLE A.6. Financing Sources of Potential Future Conservation Investment by Occupation of Respondent

\begin{tabular}{|c|c|c|}
\hline \multirow[b]{2}{*}{$\begin{array}{l}\text { Respondents Who } \\
\text { Would Finance With }\end{array}$} & \multicolumn{2}{|c|}{$\begin{array}{l}\text { Number of Homeowners } \\
\text { (in 1000s) } \\
\text { Occupation }(n=1037)\end{array}$} \\
\hline & $\begin{array}{l}\text { White Collar } \\
(n=715)\end{array}$ & $\begin{array}{l}\text { BTue Collar } \\
(n=322)\end{array}$ \\
\hline Loans & $52 \%$ & $57 \%$ \\
\hline Current Income & 11 & 10 \\
\hline Savings & 6 & 8 \\
\hline Other Sources & 31 & 25 \\
\hline
\end{tabular}

No significance. 
TABLE A.7. Financing Sources of Conservation Investment During 1984-85 by Occupation of the Second Householder

\begin{tabular}{|c|c|c|}
\hline \multirow[b]{2}{*}{$\begin{array}{l}\text { Respondents Who } \\
\text { Financed With }\end{array}$} & \multicolumn{2}{|c|}{$\begin{array}{l}\text { Number of Homeowners } \\
\text { (in } 1000 \mathrm{~s}) \\
\text { Occupat ion }(n=880)\end{array}$} \\
\hline & $\begin{array}{c}\text { White Collar } \\
(n=589) \\
\end{array}$ & $\begin{array}{l}\begin{array}{c}\text { BTue Collar } \\
(\mathrm{n}=291)\end{array} \\
\end{array}$ \\
\hline Loans & $11 \%$ & $10 \%$ \\
\hline Current Income & 66 & 63 \\
\hline Savings & 15 & 22 \\
\hline Other Sources & 8 & 6 \\
\hline
\end{tabular}

No significance.

TABLE A.8. Financing Sources of Potential Future Conservation Investment by Occupation of the Second Householder

\begin{tabular}{|c|c|c|}
\hline \multirow[b]{2}{*}{$\begin{array}{l}\text { Respondents Who } \\
\text { Would Finance With }\end{array}$} & \multicolumn{2}{|c|}{$\begin{array}{l}\text { Number of Homeowners } \\
\text { (in } 1000 \mathrm{~s}) \\
\text { Occupation }(n=819)\end{array}$} \\
\hline & $\begin{array}{l}\text { White Collar } \\
\quad(n=574)\end{array}$ & $\begin{array}{l}\text { Biue Collar } \\
(n=246)\end{array}$ \\
\hline Loans & $48 \%$ & $57 \%$ \\
\hline Current Income & 10 & 11 \\
\hline Savings & 10 & 6 \\
\hline Other Sources & 32 & 26 \\
\hline
\end{tabular}


TABLE A.9. Financing Sources of Conservation Investment During 1984-85 by Utility Service Area

\begin{tabular}{lcc} 
& $\begin{array}{c}\text { Number of Homeowners } \\
\text { (in 1000s) } \\
\text { Utility Type }\end{array}$ \\
$\begin{array}{l}\text { Investor } \\
\text { Owned }\end{array}$ & $\begin{array}{c}\text { Publicly } \\
\text { Owned } \\
\text { Utility }\end{array}$ \\
$\begin{array}{l}\text { Respondents Who } \\
\text { Financed With } \\
(n=939)\end{array}$ & $\frac{1}{(n=816)}$ \\
\hline Loans & $11 \%$ & $10 \%$ \\
Current Income & 63 & 67 \\
Savings & 19 & 19 \\
Other Sources & 8 & 4 \\
\hline No significance. & &
\end{tabular}

TABLE A.10. Financing Sources of Potential Future Conservation Investment by Utility Service Area

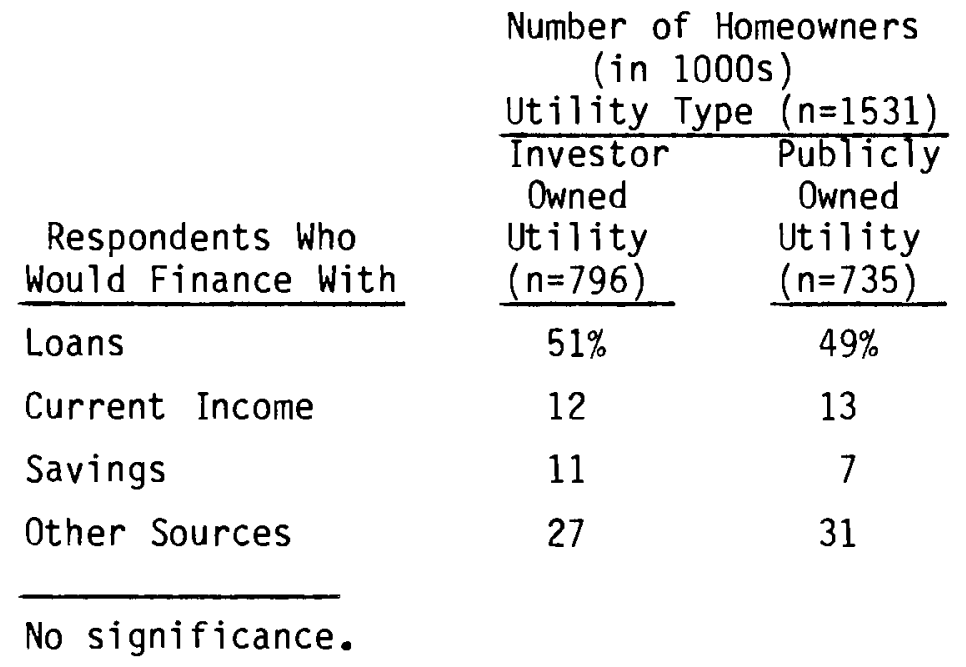


TABLE A.11. Financing Sources of Conservation Investment During 1984-85 by Decision-Making Power

\begin{tabular}{lccc} 
& \multicolumn{2}{c}{$\begin{array}{c}\text { Number of Homeowners (in 1000s) } \\
\text { Conservation Investment } \\
\text { Decisions are Made By }(n=1160)\end{array}$} \\
\cline { 2 - 3 } $\begin{array}{l}\text { Respondents Who } \\
\text { Financed With }\end{array}$ & $\frac{\begin{array}{c}\text { Respondent } \\
(n=295)\end{array}}{16 \%}$ & $\begin{array}{c}\text { Souseholder } \\
(n=328)\end{array}$ & $\begin{array}{c}\text { Shared } \\
(n=538)\end{array}$ \\
\cline { 1 - 2 } Loans & 60 & $8 \%$ & $9 \%$ \\
Current Income & 16 & 65 & 71 \\
Savings & 8 & 21 & 13 \\
Other Sources & & 6 & 6
\end{tabular}

No significance.

TABLE A.12. Financing Sources of Potential Future Conservation Investment by Decision-Making Power

\begin{tabular}{lccc} 
& $\begin{array}{c}\text { Number of Homeowners (in 1000s) } \\
\text { Conservation Investment } \\
\text { Decisions are Made By }(n=1015)\end{array}$ \\
\cline { 2 - 3 } $\begin{array}{c}\text { Respondents Who } \\
\text { Would Finance With }\end{array}$ & $\begin{array}{c}\text { Respondent } \\
(n=265)\end{array}$ & $\begin{array}{c}\text { Souseholder } \\
(n=289)\end{array}$ & $\begin{array}{c}\text { Shared } \\
(n=461)\end{array}$ \\
\cline { 2 - 3 } Loans & $48 \%$ & $51 \%$ & $44 \%$ \\
Current Income & 16 & 9 & 11 \\
Savings & 6 & 8 & 13 \\
Other Sources & 30 & 31 & 32 \\
\hline No significance. & & &
\end{tabular}


TABLE A.13. Financing Sources of Conservation Investment During $1948-85$ by Race

\begin{tabular}{lcc} 
& $\begin{array}{c}\text { Number of Homeowners } \\
\text { (in 1000s) } \\
\text { Race }(n=1714)\end{array}$ \\
\cline { 3 - 3 } $\begin{array}{c}\text { Respondents Who } \\
\text { Financed With }\end{array}$ & $\begin{array}{c}\text { White } \\
(n=1664)\end{array}$ & $\begin{array}{c}\text { Nonwhite } \\
(n=50)\end{array}$ \\
\hline Loans & $10 \%$ & $13 \%$ \\
Current Income & 64 & 64 \\
Savings & 19 & 11 \\
Other Sources & 6 & 12
\end{tabular}

Statistical testing could not be done.

TABLE A.14. Financing Sources of Potential Future Conservation Investment by Race

\begin{tabular}{lcc} 
Respondents Who & $\begin{array}{c}\text { Number of Homeowners } \\
\text { (in 1000s) } \\
\text { Race }(n=1502)\end{array}$ \\
\cline { 2 - 3 } $\begin{array}{l}\text { Would Finance With } \\
\text { Loans }\end{array}$ & $\begin{array}{c}\text { White } \\
(n=146)\end{array}$ & $\begin{array}{c}\text { Nonwhite } \\
(n=39)\end{array}$ \\
Current Income & 12 & $51 \%$ \\
Savings & 9 & 10 \\
Other Sources & 29 & 44
\end{tabular}

Statistical testing could not be done. 
TABLE A.15. Financing Sources of Conservation Investment During 1984-85 by Type of Residence

\begin{tabular}{|c|c|c|c|c|}
\hline \multirow[b]{2}{*}{$\begin{array}{l}\text { Respondents Who } \\
\text { Financed With } \\
\end{array}$} & \multicolumn{4}{|c|}{$\begin{array}{l}\text { Number of Homeowners (in 1000s) } \\
\text { Type of Residence ( } n=1755)\end{array}$} \\
\hline & $\begin{array}{l}\text { Single } \\
\text { Family } \\
\text { Detached } \\
(n=1578) \\
\end{array}$ & $\begin{array}{c}2-4 \\
\text { Units } \\
(n=29) \\
\end{array}$ & $\begin{array}{l}\text { Building with } \\
\text { More than } \\
4 \text { Units } \\
(n=7) \\
\end{array}$ & $\begin{array}{l}\text { Mobile } \\
\text { Homes } \\
\text { and Other } \\
(n=141) \\
\end{array}$ \\
\hline Loans & $10 \%$ & $21 \%$ & $0 \%$ & $11 \%$ \\
\hline Current Income & 64 & 55 & 100 & 74 \\
\hline Savings & 20 & 18 & 0 & 6 \\
\hline Other Sources & 6 & 6 & 0 & 9 \\
\hline
\end{tabular}

Statistical testing cannot be done.

TABLE A.16. Financing Sources of Potential Future Conservation Investment by Type of Residence

\begin{tabular}{|c|c|c|c|c|}
\hline \multirow[b]{2}{*}{$\begin{array}{l}\text { Respondents Who } \\
\text { Financed With }\end{array}$} & \multicolumn{4}{|c|}{$\begin{array}{c}\text { Number of Homeowners (in 1000s) } \\
\text { Type of Residence ( } n=1531)\end{array}$} \\
\hline & $\begin{array}{l}\text { Single } \\
\text { Family } \\
\text { Detached } \\
(n=1351) \\
\end{array}$ & $\begin{array}{c}2-4 \\
\text { Units } \\
(n=29)\end{array}$ & $\begin{array}{c}\text { Building with } \\
\text { More than } \\
4 \text { Units } \\
(n=11) \\
\end{array}$ & $\begin{array}{l}\text { Mobile } \\
\text { Homes } \\
\text { and Other } \\
(n=139)\end{array}$ \\
\hline Loans & $50 \%$ & $66 \%$ & $32 \%$ & $47 \%$ \\
\hline Current Income & 12 & 6 & 40 & 13 \\
\hline Savings & 9 & 6 & 0 & 8 \\
\hline Other Sources & 29 & 22 & 27 & 32 \\
\hline
\end{tabular}

Statistical testing could not be done. 
TABLE A.17. Financing Sources of Conservation Investment During 1983-85 by Working for an Electric Utility

\begin{tabular}{lcc} 
& $\begin{array}{c}\text { Number of Homeowners } \\
\text { (in 1000s) } \\
\text { Working for Electric } \\
\text { Utility }\end{array}$ \\
\cline { 2 - 3 } $\begin{array}{l}\text { Respondents Who } \\
\text { Financed With }\end{array}$ & $\frac{(n=44)}{\text { Yes }}$ & $\frac{(n=1683)}{\text { No }}$ \\
\hline Loans & $18 \%$ & $10 \%$ \\
Current Income & 54 & 65 \\
Savings & 24 & 19 \\
Other Sources & 5 & 6
\end{tabular}

Statistical testing could not be done.

TABLE A.18. Financing Sources of Potential Future Conservation Investment by Working for an Electric Utility

$\begin{array}{lcc} & \begin{array}{c}\text { Number of Homeowners } \\ \text { (in 1000s) } \\ \text { Working for Electric } \\ \text { Utility }\end{array} \\ \begin{array}{l}\text { Wespondents Who } \\ \text { Would Finance With }\end{array} & \begin{array}{c}\text { Yes } \\ \text { (n=45) }\end{array} & \begin{array}{c}\text { No } \\ (n=1463)\end{array} \\ \text { Loans } & 35 \% & 50 \% \\ \text { Current Income } & 15 & 12 \\ \text { Savings } & 8 & 9 \\ \text { Other Sources } & 43 & 29\end{array}$

Statistical testing could not be done. 
TABLE A.19. Financing Sources of Conservation Investment During 1984-85 by Agreement or Disagreement with the Statement: "The amount of energy I use is really my own affair and no one else's."

\begin{tabular}{lccc} 
& \multicolumn{2}{c}{$\begin{array}{c}\text { Number of Homeowners } \\
\text { (in 1000s) } \\
(n=1657)\end{array}$} \\
$\begin{array}{llc}\text { Respondents Who } \\
\text { Financed With }\end{array}$ & & $\begin{array}{c}\text { Disagree } \\
(n=837)\end{array}$ & $\frac{1}{(n=821)}$ \\
\hline Loans & & $13 \%$ & $8 \%$ \\
Current Income & 62 & 67 \\
Savings & 19 & 19 \\
Other Sources & 2 & 6
\end{tabular}

No significance.

TABLE A.20. Financing Sources of Potential Future Conservation Investment by Agreement or Disagreement with the Statement: "The amount of energy I use is really my own affair and no one else's."

\begin{tabular}{|c|c|c|}
\hline \multirow[b]{2}{*}{$\begin{array}{l}\text { Respondents Who } \\
\text { Would Finance With }\end{array}$} & \multicolumn{2}{|c|}{$\begin{array}{c}\text { Number of Homeowners } \\
(\text { in } 1000 s) \\
(n=1460)\end{array}$} \\
\hline & $\begin{array}{l}\text { Disagree } \\
(n=727) \\
\end{array}$ & $\begin{array}{c}\text { Agree } \\
(n=733) \\
\end{array}$ \\
\hline Loans & $51 \%$ & $50 \%$ \\
\hline Current Income & 14 & 11 \\
\hline Savings & 9 & 9 \\
\hline Other Sources & 27 & 30 \\
\hline
\end{tabular}


TABLE A.21. Financing Sources of Conservation Investment During 1984-85 by Agreement or Disagreement with the Statement: "I only use electricity when it's really needed: there's no way I could cut down."

\begin{tabular}{|c|c|c|}
\hline \multirow[b]{2}{*}{$\begin{array}{l}\text { Respondents Who } \\
\text { Financed With }\end{array}$} & \multicolumn{2}{|c|}{$\begin{array}{c}\text { Number of Homeowners } \\
(\text { in 1000s) } \\
(n=1696)\end{array}$} \\
\hline & $\begin{array}{l}\text { Disagree } \\
(n=907) \\
\end{array}$ & $\begin{array}{c}\text { Agree } \\
(n=789)\end{array}$ \\
\hline Loans & $10 \%$ & $9 \%$ \\
\hline Current Income & 67 & 62 \\
\hline Savings & 17 & 21 \\
\hline Other Sources & 6 & 7 \\
\hline
\end{tabular}

No significance.

TABLE A.22. Financing Sources of Potential Future Conservation Investment by Agreement or Disagreement with the Statement: "I only use electricity when it's really needed: there's no way I could cut down."

\begin{tabular}{|c|c|c|}
\hline \multirow[b]{2}{*}{$\begin{array}{l}\text { Respondents Who } \\
\text { Would Finance With } \\
\end{array}$} & \multicolumn{2}{|c|}{$\begin{array}{c}\text { Number of Homeowners } \\
(\text { in } 1000 s) \\
(n=1481)\end{array}$} \\
\hline & $\begin{array}{l}\text { Disagree } \\
(n=794)\end{array}$ & $\begin{array}{c}\text { Agree } \\
(n=687) \\
\end{array}$ \\
\hline Loans & $51 \%$ & $49 \%$ \\
\hline Current Income & 10 & 15 \\
\hline Savings & 9 & 8 \\
\hline Other Sources & 30 & 28 \\
\hline
\end{tabular}


TABLE A.23. Financing Sources of Conservation Investment During 1984-85 by Agreement or Disagreement with the Statement: "I have already done everything I can to conserve energy."

\begin{tabular}{|c|c|c|}
\hline \multirow[b]{2}{*}{$\begin{array}{l}\text { Respondents who } \\
\text { Financed With }\end{array}$} & \multicolumn{2}{|c|}{$\begin{array}{l}\text { Number of Homeowners } \\
(\text { in } 1000 \mathrm{~s}) \\
(\mathrm{n}=1693)\end{array}$} \\
\hline & $\begin{array}{l}\text { Disagree } \\
(\mathrm{n}=1026) \\
\end{array}$ & $\begin{array}{c}\text { Agree } \\
(\mathrm{n}=667) \\
\end{array}$ \\
\hline Loans & $10 \%$ & $10 \%$ \\
\hline Current Income & 67 & 63 \\
\hline Savings & 18 & 21 \\
\hline Other Sources & 5 & 7 \\
\hline
\end{tabular}

No significance.

TABLE A.24. Financing Sources of Potential Future Conservation Investment by Agreement or Disagreement with the Statement: "I have al ready done everything I can to conserve energy."

\begin{tabular}{|c|c|c|}
\hline \multirow[b]{2}{*}{$\begin{array}{l}\text { Respondents who } \\
\text { Would Finance With }\end{array}$} & \multicolumn{2}{|c|}{$\begin{array}{c}\text { Number of Homeowners } \\
(\text { in } 1000 \mathrm{~s}) \\
(n=1478)\end{array}$} \\
\hline & $\begin{array}{l}\text { Disagree } \\
\text { (n=955) } \\
\end{array}$ & $\begin{array}{l}\text { Agree } \\
(n=523) \\
\end{array}$ \\
\hline Loans & $50 \%$ & $49 \%$ \\
\hline Current Income & 11 & 15 \\
\hline Savings & 7 & 12 \\
\hline Other Sources & 31 & 24 \\
\hline
\end{tabular}


TABLE A.25. Financing Sources of Conservation Investment During 1984-85 by Agreement or Disagreement with the Statement: "I will invest in improving the efficiency of my home only if there are rebates to me from the utility:"

\begin{tabular}{|c|c|c|}
\hline \multirow[b]{2}{*}{$\begin{array}{l}\text { Respondents Who } \\
\text { Financed With }\end{array}$} & \multicolumn{2}{|c|}{$\begin{array}{l}\text { Number of Homeowners } \\
(\text { in } 1000 \mathrm{~s}) \\
(n=1663)\end{array}$} \\
\hline & $\begin{array}{l}\text { Disagree } \\
(n=1483) \\
\end{array}$ & $\begin{array}{l}\text { Agree } \\
(n=180)\end{array}$ \\
\hline Loans & $10 \%$ & $11 \%$ \\
\hline Current Income & 64 & 68 \\
\hline Savings & 20 & 12 \\
\hline Other Sources & 6 & 9 \\
\hline
\end{tabular}

No significance.

TABLE A.26. Financing Sources of Potential Future Conservation Investment by Agreement or Disagreement with the Statement: "I will invest in improving the efficiency of my home only if there are rebates to me from the utility."

$\begin{array}{lcc} & \begin{array}{c}\text { Number of Homeowners } \\ \text { (in 1000s) } \\ (n=1445)\end{array} \\ \begin{array}{c}\text { Wespondents Who } \\ \text { Would Finance With }\end{array} & \begin{array}{c}\text { Disagree } \\ (n=1297)\end{array} & \begin{array}{c}\text { Agree } \\ (n=148)\end{array} \\ \text { Loans } & 129 \% & 47 \% \\ \text { Current Income } & 10 & 13 \\ \text { Savings } & 29 & 5 \\ \text { Other Sources } & & 36 \\ \text { No significance. } & & \end{array}$


TABLE A.27. Financing Sources of Conservation Investment During 1984-85 by Disagreement or Agreement with the Statement: "It's silly to conserve electricity, because the utility just turns around and charges more for what you do use."

\begin{tabular}{lcc} 
& $\begin{array}{c}\text { Number of Homeowners } \\
\text { (in 1000s) } \\
\text { ( } n=1657)\end{array}$ \\
$\begin{array}{l}\text { Respondents Who } \\
\text { Financed With }\end{array}$ & $\begin{array}{c}\text { Disagree } \\
(n=1135)\end{array}$ & $\begin{array}{c}\text { Agree } \\
(n=521)\end{array}$ \\
\cline { 1 - 2 } Loans & $11 \%$ & $10 \%$ \\
Current Income & 64 & 69 \\
Savings & 20 & 13 \\
Other Sources & 6 & 8 \\
No significance. & &
\end{tabular}

TABLE A.28. Financing Sources of Potential Future Conservation Investment by Disagreement or Agreement with the Statement: "It's silly to conserve electricity, because the utility just turns around and charges more for what you do use."

\begin{tabular}{lcc} 
& $\begin{array}{c}\text { Number of Homeowners } \\
\text { (in 1000s) } \\
(n=1447)\end{array}$ \\
$\begin{array}{l}\text { Would Finance With } \\
\text { Loans }\end{array}$ & $\begin{array}{c}\text { Disagree } \\
(n=978)\end{array}$ & $\begin{array}{c}\text { Agree } \\
(n=469)\end{array}$ \\
\cline { 1 - 2 } Current Income & 11 & $51 \%$ \\
Savings & 9 & 15 \\
Other Sources & 29 & 6
\end{tabular}

No significance. 
TABLE A.29. Financing Sources of Conservation Investment During 1984-85 by Agreement or Disagreement with the Statement: "My conservation efforts won't have much effect one way or the other on the availability of electricity."

\begin{tabular}{lcc} 
& $\begin{array}{c}\text { Number of Homeowners } \\
(\text { in 1000s) } \\
(n=1684)\end{array}$ \\
$\begin{array}{l}\text { Respondents Who } \\
\text { Financed With }\end{array}$ & $\begin{array}{c}\text { Disagree } \\
(n=1322)\end{array}$ & $\begin{array}{c}\text { Agree } \\
(n=363)\end{array}$ \\
\hline Loans & $11 \%$ & $10 \%$ \\
Current Income & 63 & 71 \\
Savings & 20 & 14 \\
Other Sources & 6 & 5 \\
No significance. & &
\end{tabular}

TABLE A.30. Financing Sources of Potential Future Conservation Investment by Agreement or Disagreement with the Statement: "My conservation efforts won't have much effect one way or the other on the availability of electricity."

$\begin{array}{lcc} & \begin{array}{c}\text { Number of Homeowners } \\ \text { (in 1000s) } \\ (n=1482)\end{array} \\ \begin{array}{l}\text { Would Finance With } \\ \text { Loans }\end{array} & \begin{array}{c}\text { Disagree } \\ (n=1153)\end{array} & \begin{array}{c}\text { Agree } \\ (n=329)\end{array} \\ \text { Current Income } & 49 \% & 51 \% \\ \text { Savings } & 12 & 14 \\ \text { Other Sources } & 9 & 8 \\ \end{array}$

No significance. 
TABLE A.31. Financing Sources of Conservation Investment During 1984-85 by Disagreement or Agreement with the Statement: "Conserving energy is the best way to protect the environment."

\begin{tabular}{|c|c|c|}
\hline \multirow[b]{2}{*}{$\begin{array}{l}\text { Respondents who } \\
\text { Financed With }\end{array}$} & \multicolumn{2}{|c|}{$\begin{array}{l}\text { Number of Homeowners } \\
\text { (in } 1000 \mathrm{~s}) \\
(n=1599)\end{array}$} \\
\hline & $\begin{array}{l}\text { Di sagree } \\
(n=335) \\
\end{array}$ & $\begin{array}{c}\text { Agree } \\
(n=1264) \\
\end{array}$ \\
\hline Loans & $10 \%$ & $10 \%$ \\
\hline Current Income & 70 & 64 \\
\hline Savings & 15 & 20 \\
\hline Other Sources & 5 & 6 \\
\hline
\end{tabular}

No significance.

TABLE A.32. Financing Sources of Potential Future Conservation Investment by Disagreement or Agreement with the Statement: "Conserving energy is the best way to protect the environment."

\begin{tabular}{lcc}
$\begin{array}{c}\text { Respondents Who } \\
\text { Would Finance With }\end{array}$ & $\begin{array}{c}\text { Number of Homeowners } \\
\text { (in 1000s) } \\
\text { ( } n=1394)\end{array}$ \\
\cline { 1 - 2 } Loans & $\frac{0}{\text { Disagree }}(\mathrm{n}=281)$ & $\begin{array}{c}\text { Agree } \\
(n=1113)\end{array}$ \\
Current Income & $14 \%$ & $51 \%$ \\
Savings & 8 & 12 \\
Other Sources & 38 & 8 \\
No significance. & &
\end{tabular}


TABLE A.33. Financing Sources of Conservation Investment During 1984-85 by Disagreement or Agreement with the Statement: "It's our responsibility to conserve electricity for future generations."

\begin{tabular}{|c|c|c|}
\hline \multirow[b]{2}{*}{$\begin{array}{l}\text { Respondents Who } \\
\text { Financed With }\end{array}$} & \multicolumn{2}{|c|}{$\begin{array}{c}\text { Number of Homeowners } \\
\text { (in 1000s) } \\
\text { ( } n=1669)\end{array}$} \\
\hline & $\begin{array}{r}\text { Disagree } \\
(n=207) \\
\end{array}$ & $\begin{array}{c}\text { Agree } \\
(n=1462) \\
\end{array}$ \\
\hline Loans & $9 \%$ & $10 \%$ \\
\hline Current Income & 64 & 65 \\
\hline Savings & 23 & 19 \\
\hline Other Sources & 4 & 7 \\
\hline
\end{tabular}

TABLE A.34. Financing Sources of Potential Future Conservation Investment by Disagreement or Agreement with the Statement: "It's our responsibility to conserve electricity for future generations."

\begin{tabular}{|c|c|c|}
\hline \multirow[b]{2}{*}{$\begin{array}{l}\text { Respondents Who } \\
\text { Would Finance With }\end{array}$} & \multicolumn{2}{|c|}{$\begin{array}{c}\text { Number of Homeowners } \\
(\text { in } 1000 \mathrm{~s}) \\
(n=1461)\end{array}$} \\
\hline & $\begin{array}{r}\text { Disagree } \\
(n=174) \\
\end{array}$ & $\begin{array}{c}\text { Agree } \\
(n=1287) \\
\end{array}$ \\
\hline Loans & $47 \%$ & $51 \%$ \\
\hline Current Income & 16 & 12 \\
\hline Savings & 8 & 8 \\
\hline Other Sources & 30 & 29 \\
\hline
\end{tabular}


TABLE A.35. Financing Sources of Conservation Investment During 1984-85 by Disagreement or Agreement with the Statement: "Conserving energy is the best way to maintain my lifestyle."

\begin{tabular}{lcc} 
& $\begin{array}{c}\text { Number of Homeowners } \\
\text { (in 1000s) } \\
\text { ( } n=1402)\end{array}$ \\
$\begin{array}{l}\text { Respondents Who } \\
\text { Financed With }\end{array}$ & $\begin{array}{c}\text { Disagree } \\
(n=488)\end{array}$ & $\begin{array}{c}\text { Agree } \\
(n=1122)\end{array}$ \\
\hline Loans & $9 \%$ & $11 \%$ \\
Current Income & 69 & 63 \\
Savings & 17 & 20 \\
Other Sources & 6 & 6 \\
No significance. & &
\end{tabular}

TABLE A.36. Financing Sources of Potential Future Conservation Investment by Disagreement or Agreement with the Statement: "Conserving energy is the best way to maintain my lifestyle."

$\begin{array}{lcc}\begin{array}{c}\text { Number of Homeowners } \\ \text { (in 1000s) } \\ (n=1402)\end{array} \\ \begin{array}{l}\text { Respondents Who } \\ \text { Would Finance With }\end{array} & \begin{array}{c}\begin{array}{c}\text { Disagree } \\ (n=434)\end{array} \\ \text { Loans }\end{array} & \begin{array}{c}\text { Agree } \\ (n=168)\end{array} \\ \text { Current Income } & 12 & 49 \% \\ \text { Savings } & 11 & 13 \\ \text { Other Sources } & 25 & 29\end{array}$

No significance. 
TABLE A.37. Financing Sources of Conservation Investment During 1984-85 by Disagreement or Agreement with the Statement: "I would only make conservation improvements which would enhance the value of my home."

\begin{tabular}{lcc} 
& $\begin{array}{c}\text { Number of Homeowners } \\
\text { (in 1000s) } \\
(n=1697)\end{array}$ \\
$\begin{array}{l}\text { Respondents Who } \\
\text { Financed With }\end{array}$ & $\begin{array}{c}\text { Disagree } \\
(n=1308)\end{array}$ & $\begin{array}{c}\text { Agree } \\
(n=389)\end{array}$ \\
\hline Loans & $10 \%$ & $12 \%$ \\
Current Income & 64 & 68 \\
Savings & 20 & 14 \\
Other Sources & 6 & 6
\end{tabular}

No significance.

TABLE A.38. Financing Sources of Potential Future Conservation Investment by Disagreement or Agreement with the Statement: "I would only make conservation improvements which would enhance the value of my home."

\begin{tabular}{|c|c|c|}
\hline \multirow[b]{2}{*}{$\begin{array}{l}\text { Respondents Who } \\
\text { Would Finance With }\end{array}$} & \multicolumn{2}{|c|}{$\begin{array}{c}\text { Number of Homeowners } \\
(\text { in } 1000 \mathrm{~s}) \\
(n=1481)\end{array}$} \\
\hline & $\begin{array}{l}\text { Disagree } \\
(\mathrm{n}=1166) \\
\end{array}$ & $\begin{array}{c}\text { Agree } \\
(n=315) \\
\end{array}$ \\
\hline Loans & $49 \%$ & $51 \%$ \\
\hline Current Income & 11 & 17 \\
\hline Savings & 10 & 4 \\
\hline Other Sources & 30 & 28 \\
\hline
\end{tabular}


TABLE A.39. Financing Sources of Conservation Investment During 1984-85 by Disagreement or Agreement with the Statement: "Electricity prices in the Northwest aren't high enough to necessitate conservation."

Respondents Who

Financed With

Loans

Current Income

Savings

Other Sources
Number of Homeowners

(in 1000s)

$(n=1685)$

\begin{tabular}{ll}
$\begin{array}{l}\text { Disagree } \\
(n=1563\end{array}$ & $\begin{array}{c}\text { Agree } \\
(n=122)\end{array}$ \\
\hline $11 \%$ & $\frac{4 \%}{2}$
\end{tabular}

64

76

19

18

6

\section{2}

Statistical testing could not be done.

TABLE A.40. Financing Sources of Potential Future Conservation Investment by Disagreement or Agreement with the Statement: "Electricity prices in the Northwest aren't high enough to necessitate conservation."

\begin{tabular}{|c|c|c|}
\hline & \multicolumn{2}{|c|}{$\begin{array}{c}\text { Number of Homeowners } \\
(\text { in 1000s) } \\
(n=1480)\end{array}$} \\
\hline $\begin{array}{l}\text { Respondents Who } \\
\text { Would Finance With }\end{array}$ & $\begin{array}{l}\text { Disagree } \\
(n=1371)\end{array}$ & $\begin{array}{c}\text { Agree } \\
(n=109)\end{array}$ \\
\hline Loans & $49 \%$ & $56 \%$ \\
\hline Current Income & 13 & 13 \\
\hline Savings & 9 & 3 \\
\hline Other Sources & 29 & 28 \\
\hline
\end{tabular}

Statistical testing could not be done. 
TABLE A.41. Financing Sources of Conservation Investment During 1984-85 by Disagreement or Agreement with the Statement: "With the current power surplus in the Northwest, there is no need to conserve electricity."

\begin{tabular}{lcc} 
& $\begin{array}{c}\text { Number of Homeowners } \\
\text { (in 1000s) } \\
(n=1723)\end{array}$ \\
$\begin{array}{l}\text { Respondents Who } \\
\text { Financed With }\end{array}$ & $\frac{\begin{array}{c}\text { Disagree } \\
(n=1639)\end{array}}{10 \%}$ & $\begin{array}{c}\text { Agree } \\
(n=84)\end{array}$ \\
\hline Loans & 65 & $67 \%$ \\
Current Income & 19 & 13 \\
Savings & 6 & 7 \\
Other Sources & & 67
\end{tabular}

Statistical testing could not be done.

TABLE A.42. Financing Sources of Potential Future Conservation Investment by Disagreement or Agreement with the Statement: "With the current power surplus in the Northwest, there is no need to conserve electricity."

$\begin{array}{lcc} & \begin{array}{c}\text { Number of Homeowners } \\ (\text { in 1000s) } \\ (n=1511)\end{array} \\ \begin{array}{l}\text { Wespondents Who } \\ \text { Would Finance With }\end{array} & \begin{array}{c}\text { Disagree } \\ (n=1451)\end{array} & \begin{array}{c}\text { Agree } \\ (n=60)\end{array} \\ \text { Loans } & 12 & 53 \% \\ \text { Current Income } & 9 & 19 \\ \text { Savings } & 29 & 26 \\ \text { Other Sources } & & 3\end{array}$

Statistical testing could not be done. 
TABLE A.43. Financing Sources of Conservation Investment During 1984-85 by Disagreement or Agreement with the Statement: "Most people who conserve electricity do so to save money."

\begin{tabular}{lcc} 
& $\begin{array}{c}\text { Number of Homeowners } \\
(\text { in 1000s }) \\
(n=1731)\end{array}$ \\
$\begin{array}{l}\text { Respondents Who } \\
\text { Financed With }\end{array}$ & $\begin{array}{c}\text { Disagree } \\
(n=117)\end{array}$ & $\begin{array}{c}\text { Agree } \\
(n=1613)\end{array}$ \\
\hline Loans & $5 \%$ & $11 \%$ \\
Current Income & 80 & 63 \\
Savings & 10 & 20 \\
Other Sources & 4 & 7
\end{tabular}

Statistical testing could not be done.

TABLE A.44. Financing Sources of Potential Future Conservation Investment by Disagreement or Agreement with the Statement: "Most people who conserve electricity do so to save money."

\begin{tabular}{lcc} 
& $\begin{array}{c}\text { Number of Homeowners } \\
(\text { in 1000s) } \\
(n=1508)\end{array}$ \\
$\begin{array}{l}\text { Respondents Who } \\
\text { Would Finance With }\end{array}$ & $\begin{array}{c}\text { Disagree } \\
(n=89)\end{array}$ & $\begin{array}{c}\text { Agree } \\
(n=1419)\end{array}$ \\
\cline { 2 - 3 } Loans & $52 \%$ & $49 \%$ \\
Current Income & 22 & 12 \\
Savings & 2 & 9 \\
Other Sources & 25 & 29
\end{tabular}

Statistical testing could not be done. 
TABLE A.45. Financing Sources of Conservation Investment During 1984-85 by Disagreement or Agreement with the Statement: "I would invest in energy conservation measures because it increases the comfort of my home."

\begin{tabular}{|c|c|c|}
\hline \multirow[b]{2}{*}{$\begin{array}{l}\text { Respondents Who } \\
\text { Financed With }\end{array}$} & \multicolumn{2}{|c|}{$\begin{array}{l}\text { Number of Homeowners } \\
(\text { in } 1000 s) \\
(n=1728)\end{array}$} \\
\hline & $\begin{array}{r}\text { Disagree } \\
(n=106) \\
\end{array}$ & $\begin{array}{l}\text { Agree } \\
(n=1622)\end{array}$ \\
\hline Loans & $8 \%$ & $10 \%$ \\
\hline Current Income & 69 & 64 \\
\hline Savings & 15 & 19 \\
\hline Other Sources & 7 & 6 \\
\hline
\end{tabular}

TABLE A.46. Financing Sources of Potential Future Conservation Investment by Disagreement or Agreement with the Statement: "I would invest in energy conservation measures because it increases the comfort of my home."

Statistical testing could not be done.

\begin{tabular}{lcc}
$\begin{array}{c}\text { Respondents Who } \\
\text { Would Finance With }\end{array}$ & $\begin{array}{c}\text { Number of Homeowners } \\
\text { (in 1000s) } \\
(n=1512)\end{array}$ \\
\cline { 1 - 2 } Loans & $\begin{array}{c}\text { Disagree } \\
(n=104)\end{array}$ & $\begin{array}{c}\text { Agree } \\
(n=1407)\end{array}$ \\
Current Income & $44 \%$ & $50 \%$ \\
Savings & 23 & 12 \\
Other Sources & 4 & 9 \\
& 29 & 28
\end{tabular}

Statistical testing could not be done. 
TABLE A.47. Financing Sources of Conservation Investment During 1984-85 by Agreement or Disagreement with the Statement: "I don't care if my clothes are unstylish as long as I like them."

\begin{tabular}{|c|c|c|}
\hline \multirow[b]{2}{*}{$\begin{array}{l}\text { Respondents Who } \\
\text { Financed With } \\
\end{array}$} & \multicolumn{2}{|c|}{$\begin{array}{c}\text { Number of Homeowners } \\
(\text { in } 1000 \mathrm{~s}) \\
(\mathrm{n}=1682)\end{array}$} \\
\hline & $\begin{array}{l}\text { Disagree } \\
(n=426)\end{array}$ & $\begin{array}{c}\text { Agree } \\
(n=1257)\end{array}$ \\
\hline Loans & $12 \%$ & $9 \%$ \\
\hline Current Income & 63 & 65 \\
\hline Savings & 19 & 19 \\
\hline Other Sources & 6 & 7 \\
\hline
\end{tabular}

TABLE A.48. Financing Sources of Potential Future Conservation Investment by Agreement or Disagreement with the Statement: "I don't care if my clothes are unstylish as long as I like them."

\begin{tabular}{lcc} 
& $\begin{array}{c}\text { Number of Homeowners } \\
\text { (in 1000s) } \\
(n=1483)\end{array}$ \\
$\begin{array}{c}\text { Wespondents Who } \\
\text { Would Finance With }\end{array}$ & $\begin{array}{c}\text { Disagree } \\
(n=395)\end{array}$ & $\begin{array}{c}\text { Agree } \\
(n=1088)\end{array}$ \\
\hline Loans & 13 & $50 \%$ \\
Current Income & 11 & 12 \\
Savings & 26 & 30 \\
Other Sources & & 8
\end{tabular}

No significance. 
TABLE A.49. Financing Sources of Conservation Investment During 1984-85 by Agreement or Disagreement with the Statement: "I consider myself a do it yourselfer."

\begin{tabular}{lcc} 
& $\begin{array}{c}\text { Number of Homeowners } \\
(\text { in 1000s) } \\
(n=1694)\end{array}$ \\
$\begin{array}{l}\text { Respondents Who } \\
\text { Financed With }\end{array}$ & $\frac{\begin{array}{c}\text { Disagree } \\
(n=299)\end{array}}{18 \%}$ & $\begin{array}{c}\text { Agree } \\
(n=1395)\end{array}$ \\
Loans & 61 & $9 \%$ \\
Current Income & 16 & 66 \\
Savings & 5 & 6 \\
Other Sources & & \\
\hline No significance. & &
\end{tabular}

TABLE A.50. Financing Sources of Potential Future Conservation Investment by Agreement or Disagreement with the Statement: "I consider myself a do it yourselfer."

\begin{tabular}{lcc} 
& $\begin{array}{c}\text { Number of Homeowners } \\
\text { (in 1000s) } \\
(n=1477)\end{array}$ \\
$\begin{array}{l}\text { Would Finance With } \\
\text { Loans }\end{array}$ & $\begin{array}{c}\text { Disagree } \\
(n=277)\end{array}$ & $\begin{array}{c}\text { Agree } \\
(n=1200)\end{array}$ \\
\cline { 2 - 3 } Current Income & 19 & $51 \%$ \\
Savings & 8 & 11 \\
Other Sources & 26 & 9
\end{tabular}

No significance. 
TABLE A.51. Financing Sources of Conservation Investment During 1984-85 by Agreement or Disagreement with the Statement: "I consult consuiner reports or similar publications before making major purchases."

\begin{tabular}{|c|c|c|}
\hline \multirow[b]{2}{*}{$\begin{array}{l}\text { Respondents who } \\
\text { Financed With }\end{array}$} & \multicolumn{2}{|c|}{$\begin{array}{c}\text { Number of Homeowners } \\
(\text { in } 1000 \mathrm{~s}) \\
(\mathrm{n}=1660)\end{array}$} \\
\hline & $\begin{array}{l}\text { Disagree } \\
(n=524) \\
\end{array}$ & $\begin{array}{l}\text { Agree } \\
(n=1136)\end{array}$ \\
\hline Loans & $9 \%$ & $11 \%$ \\
\hline Current Income. & 67 & 65 \\
\hline Savings & 17 & 19 \\
\hline Other Sources & 7 & 6 \\
\hline
\end{tabular}

TABLE A.52. Financing Sources of Potential Future Conservation Investment by Agreement or Disagreement with the Statement: "I consult consumer reports or similar publications before making major purchases."

Number of Homeowners

Respondents Who (in 1000s) $(n=1476)$

Would Finance With

Loans

\begin{tabular}{|c|c|}
\hline \multicolumn{2}{|c|}{$(n=1476)$} \\
\hline $\begin{array}{l}\text { Disagree } \\
(n=480)\end{array}$ & $\begin{array}{c}\text { Agree } \\
(n=996)\end{array}$ \\
\hline & \\
\hline
\end{tabular}

Current Income

19

13

Savings

12

8

Other Sources

32

27

No significance. 
Fang, J. M. 1985. Household Attitudes Toward Energy Conservation in the Pacific Northwest: Overview and Comparisons. PNL-5405, Pacific Northwest Laboratory, Richland, Washington.

Fang, J. M., M. P. Hattrup, R. T. Nordi, S. A. Shankle, and D. L. Ivey. 1986. Household Energy Conservation Attitudes and Behaviors in the Northwest: Tracking Changes Between 1983 and 1985, PNL-5892, Pacific Northwest Laboratory, Richland, Washington, October.

RMH Research Inc. 1984a. Marketing Environment for Energy Conservation in the Pacific Northwest, prepared for the Pacific Northwest Laboratory by RMH Research, Inc. River Edge, New Jersey.

RMH Research Inc. 1984b. Marketing Environment for Solar and Heat Pump Water Heaters, prepared for the Pacific Northwest Laboratory by RMH Research Inc., River Edge, New Jersey. 


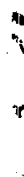

'

n 1 


\section{DISTR IBUTION}

No. of

Copies

OFFS ITE

2 T. 0liver MS/KRR

Bonneville Power Administration P.0. Box 3621

Portland, OR 97208

2 L. Saito

Bonneville Power Administration KRP

1002 N.E. Holloday Street

P.0. Box 3621

Portland, OR 97205

F. Abel

Senior Economist

Office of Building \& Community Systems

U.S. Department of Energy

Forrestal Building CE-11

1000 Independence Ave., S.W

Washington, DC 20585

2 DOE Technical Information Center
No. of

Copies

ONSITE

DOE Richland Operations Office

J. J. Sutey

22 Pacific Northwest Laboratory

J. M Fang

M. P. Hattrup

D. L. Ivey (10)

B. L. Mohler

R. T. Nordi

S. A. Shankle

Publishing Coordination MH (2)

Technical Report Files (5) 
$\checkmark$

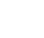

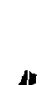

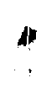

$x$
$\vdots$
$\vdots$
1

I

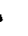

